GEORGE J. BOR JAS

Harvard University

R ICHARD B. FREEMAN

Harvard University

LAWRENCE F. KATZ

Harvard University

\title{
How Much Do Immigration and Trade Affect Labor Market Outcomes?
}

IMMIGRATION AND TRADE-particularly with less developed countries (LDCs) - have become more significant to the U.S. economy since the 1960s than they were earlier in the postwar period. The number of immigrants relative to native-born workers has risen; an increasing proportion of immigrants come from less developed countries; and a disproportionate number of immigrants have relatively little schooling. The ratio of exports and imports to GDP has risen as well, and an increasing proportion of imports have come from less developed countries. Immigration and trade have thus increased the effective labor supply of less skilled workers in the United States, with potential consequences for relative wages and employment.

To what extent might the economic woes of less skilled and lowpaid American workers be attributed to changes in trade or immigration? To what extent have immigration and trade benefited other Americans?

These questions have spurred considerable debate in recent years. Some analysts stress the potentially adverse distributional effects of immigration and trade on low-income Americans. Others stress their potentially positive effects on the economy. Standard models suggest

We are grateful to John Abowd, John DiNardo, Robert Lawrence, and Matthew Slaughter for helpful suggestions; to Marianne Bertrand, Alida Castillo-Freeman, and Gabriel Hanz for excellent research assistance; to Howard Shatz and Kenneth Troske for providing some of the data used in the paper; and to the National Science Foundation for research support. 
that both immigration and trade alter national output and the distribution of income through the same mechanism-by increasing the nation's implicit supply of relatively scarce factors of production-so that their benefits and distributional costs are intrinsically related. While there is empirical evidence that trade may have more far-reaching benefits on economic performance, and one could argue that immigration may have positive or negative effects on the aggregate economy through economies or diseconomies of scale, trade and immigration are still likely to affect relative economic outcomes. ' Factors for which immigration and trade are good substitutes will lose relative to factors that are complementary. ${ }^{2}$

This paper provides new estimates of the impact of immigration and trade on the U.S. labor market, taking account of the extensive debate that has developed since our earlier work. ${ }^{3}$ We first review the dimensions of immigration and trade flows to the United States since the 1960s. Then we examine the relation between economic outcomes for native workers and immigrant flows to regional labor markets. We next use the aggregate "factor proportions approach" to simulate the impact of immigration and trade on national supplies of labor by skill under different counterfactuals. We also consider Adrian Wood's controversial claim that using input coefficients for the appropriate importcompeting activities leads to much larger trade effects than we, or others, have estimated. ${ }^{4}$ We then use the factor proportions approach to examine the contributions of immigration and trade to recent changes in U.S. educational wage differentials and attempt to provide a broader assessment of the impact of immigration on the incomes of U.S. natives. Finally, we offer some concluding thoughts.

Our major findings are as follows:

- Immigration does not have a consistent, discernible effect on area

1. On the beneficial effects of openness to trade on national economic performance, see Frankel and Romer (1996) and Sachs and Warner (1995).

2. This will be true unless essentially no unskilled American works in importcompeting activities (because U.S. firms have shifted production to utterly different products) or competes with immigrants in the labor market (because all immigrants have skills that complement those of natives). With a fixed linear homogeneous production function, if trade or immigration raises GDP a lot, there will necessarily be large effects on the distribution of income (and small effects if GDP is raised slightly).

3. Borjas, Freeman, and Katz (1992).

4. Wood $(1994,1995)$. 
economic outcomes; other regional factors dominate the ups and downs of area economies.

- The location decisions of the native population respond to immigration; the native flow to the primary immigrant-receiving state, California, has been greatly reduced by the influx of immigrants since 1970.

- Immigration has had a marked adverse impact on the economic status of the least skilled U.S. workers (high school dropouts and those in the bottom 20 percent of the wage distribution).

- Trade has had small effects on the overall implicit labor supply of the less skilled. However, the trade effect is larger if one assumes that economic activities displaced by imports employ technologies comparable to the least skilled plants in U.S. manufacturing industries.

These are not the final words on the effects of immigration and trade on the job market. We do not explore all of the possible avenues by which these flows influence labor market outcomes. For instance, we do not estimate the extent to which immigrants may take jobs that no native would take and so may overstate the effect of immigration on the less skilled. ${ }^{5}$ Nor do we explore the potential effects of trade on native outcomes that occur entirely through prices (with no observed change in trade quantities), and thus we may understate the distributional effects of trade on outcomes.

\section{The Two Shocks}

The starting point for our analysis is the significant increase in immigration and trade that has occurred in the United States since the 1960s. While neither immigration nor trade flows are entirely exogenous shocks to the U.S. job market, the huge changes in recent years have come primarily from developments that are unrelated to contemporaneous labor market conditions in the United States. On the immigration side, the major impetus for the increased flow of legal immigration from less developed countries were the 1965 Amendments to

5. Hamermesh (1997) contrasts the quality of jobs held by immigrants and by natives and finds little support for this claim, so we doubt that this is a major consideration in assessing the effect of immigration. 
Table 1. The Foreign-Born Population of the United States and Its National Origins, 1960-96

Units as indicated

\begin{tabular}{lccrrr}
\hline & \multicolumn{5}{c}{ Foreign-born population } \\
\cline { 2 - 6 } Item & 1960 & 1970 & 1980 & 1990 & 1996 \\
\hline In millions & 9.7 & 9.7 & 14.1 & 19.8 & 24.6 \\
As percentage of entire population & 5.4 & 4.8 & 6.2 & 7.9 & 9.3 \\
Distribution by origin & & & & & \\
$\quad$ Canada and Europe & 84 & 68 & 43 & 26 & $\ldots$ \\
Caribbean and Latin America & 9 & 19 & 31 & 43 & $\ldots$ \\
Asia & 5 & 9 & 18 & 25 & $\ldots$ \\
Other & 2 & 4 & 8 & 6 & $\ldots$ \\
\hline
\end{tabular}

Source: Authors' calculations. Data for 1960 are from U.S. Bureau of the Census. Historical Statistics of the United States, Colonial Times to 1870, vol. I (Department of Commerce, 1975). Data for 1970-90 are from Statistical Abstract of the United States (various years). Data for 1996 are from the Census Bureau and are available on the bureau's worldwide web page.

a. Percent

the Immigration and Nationality Act. ${ }^{6}$ Illegal immigration has also responded to policy developments (such as the ending of the bracero, or guest worker, program in 1964), but probably depends more on the huge wage differential between Mexico and the United States than on U.S. labor market developments. ${ }^{7}$ On the trade side, the worldwide movement toward more open trade, the increased productivity of workers in LDCs, the entry of China into the world economy, and changes in exchange rates have altered trade flows, irrespective of changes in the U.S. labor market.

\section{Immigration}

Immigration began to surge not long after the enactment of the 1965 amendments, reversing a long downward trend in the foreign-born share of the U.S. population. Table 1 quantifies these patterns. In 1960, 5.4 percent of the population was foreign-born; in 1970, the foreign-born share bottomed out at 4.8 percent. Between 1970 and 1996, the number of foreign-born persons increased by 15 million, raising the foreign-

6. Borjas (1990, chap. 2) provides a brief summary of the policy changes initiated by the 1965 legislation.

7. In particular, the illegal flow has certainly not been motivated by rising real wages for less skilled workers in the United States. Those wages have fallen in recent years. Hanson and Spilimbergo (1997) show that illegal immigration from Mexico (as proxied by border apprehensions) is particularly sensitive to labor market conditions in Mexico. 
Figure 1. Percentage of Adult Population that Was Foreign Born, 1950-90a

Percent

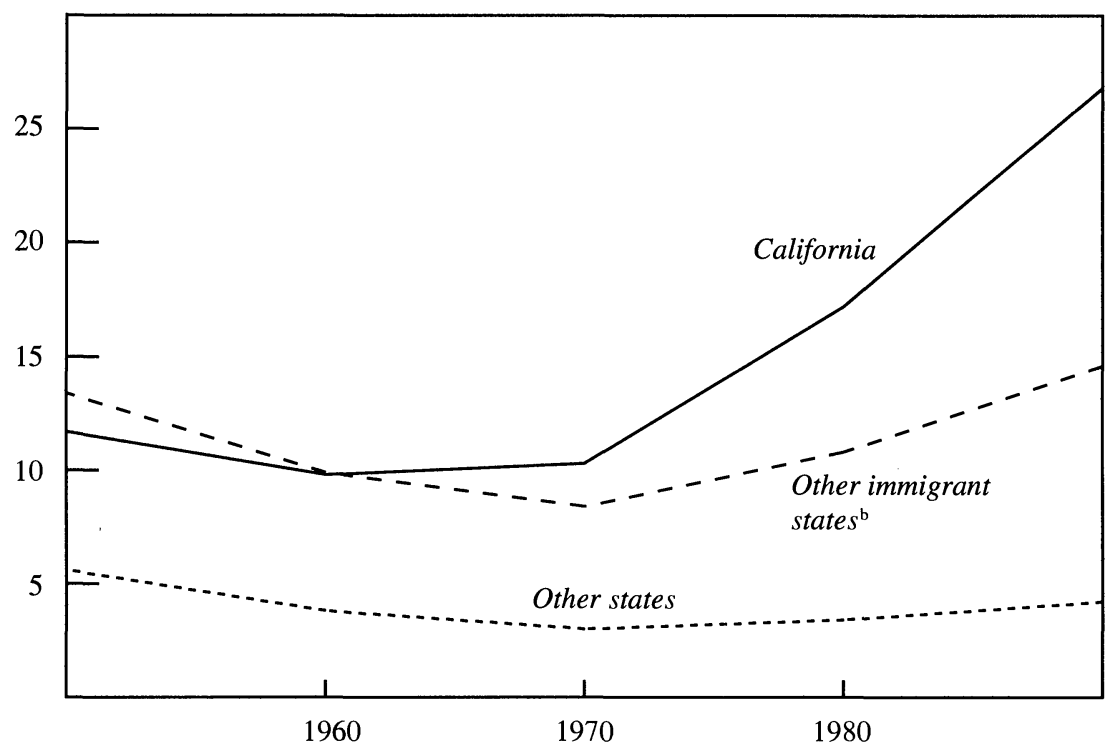

Source: Authors' calculations based on data from the census Public Use Microdata Sample (PUMS) (various years); see table 2 below for details.

a. Adults are aged eighteen to sixty-four.

b. New York, New Jersey, Illinois, Florida, and Texas.

born share of the U.S. population to 7.9 percent in 1990 and 9.3 percent in 1996. During this period, the proportion of immigrants from LDCs was rising.

Historically, immigrants have clustered in a small number of geographic areas, and this concentration has increased over time. In 1960, 60 percent of immigrants lived in one of the six main immigrantreceiving states: California, New York, Texas, Florida, New Jersey, and Illinois. By 1990, 75 percent of immigrants lived in these states, and over 33 percent lived in California alone. This geographic concentration reflects the propensity of immigrants to enter the United States through a limited number of gateway cities or states and spread out slowly to other areas of the country in subsequent years. ${ }^{8}$ Figure 1 illustrates the impact of the immigrant supply shock on the percent of

8. Bartel (1989). 
the adult population (aged eighteen to sixty-four) that was foreign-born in California, in other immigrant-receiving states, and in the rest of the country over the period 1950-90. Before 1970, the foreign-born share was stable or declining in each region. Between 1970 and 1990, this share almost tripled in California (rising from 10.3 percent to 26.8 percent), almost doubled in the other immigrant-receiving states (from 8.4 to 14.6 percent), and rose slightly in the rest of the country (from 3.0 to 4.2 percent).

The effect of immigration on native labor depends critically on the distribution of skills between immigrants and natives. If the skill distribution of immigrants matches that of natives, immigration will not affect the relative supply of skills and thus will not change the structure of wages. By contrast, if immigrants are less skilled than natives, immigration will shift the distribution of income toward the more skilled, and conversely if immigrants are more skilled than natives.

Table 2 compares the distributions of years of schooling for immigrants and natives in the United States and in California for 1990 and 1995, and also reports the immigrant contribution to the labor supply of workers with different years of schooling. The distribution of immigrants by educational attainment is more dispersed than that of natives. A disproportionately high number of immigrants have fewer than nine years of schooling, but also, a disproportionately high number have more than sixteen years of schooling. On average, however, immigrants have fewer years of schooling than natives-a difference that has grown over the past two decades, as the mean years of schooling in the immigrant population increased less rapidly than the mean years of schooling of natives. As a result, the immigrant contribution to the supply of skills has become increasingly concentrated in the lower educational categories. By 1995, one-half of workers with fewer than nine years of schooling and one-third of workers with fewer than twelve years of schooling were immigrants.

In 1995, over 30 percent of the working-age population in California was foreign-born; consequently, one can learn much by comparing California's experience with that of other states. California has an exceptionally large less educated immigrant population that stands in contrast to the high number of well-educated natives. The lower panel of table 2 shows that by 1995, 90 percent of Californians with fewer 
Table 2. Distribution of Natives and Immigrants by Educational Attainment, United States and California, 1990 and 1995

Percent

\begin{tabular}{|c|c|c|c|c|c|c|}
\hline \multirow[b]{2}{*}{$\begin{array}{l}\text { Region and } \\
\text { years of } \\
\text { schooling }\end{array}$} & \multicolumn{3}{|c|}{1990 census data } & \multicolumn{3}{|c|}{1995 CPS data } \\
\hline & Natives & Immigrants & $\begin{array}{l}\text { Immigrant } \\
\text { share in } \\
\text { skill group }\end{array}$ & Natives & Immigrants & $\begin{array}{c}\text { Immigrant } \\
\text { share in } \\
\text { skill group }\end{array}$ \\
\hline \multicolumn{7}{|l|}{ United States } \\
\hline Fewer than 9 & 4.2 & 22.4 & 36.9 & 2.8 & 22.6 & 49.6 \\
\hline 9 to 11 & 14.0 & 16.0 & 11.1 & 9.9 & 12.3 & 13.1 \\
\hline 12 & 32.0 & 20.1 & 6.4 & 34.6 & 24.8 & 8.0 \\
\hline 13 to 15 & 29.5 & 21.1 & 7.2 & 30.0 & 19.0 & 7.1 \\
\hline 16 & 13.8 & 12.0 & 8.6 & 15.7 & 13.5 & 9.4 \\
\hline More than 16 & 6.6 & 8.4 & 12.1 & 7.1 & 7.8 & 11.7 \\
\hline \multicolumn{7}{|l|}{ California } \\
\hline Fewer than 9 & 2.2 & 28.6 & 82.6 & 1.5 & 30.3 & 90.1 \\
\hline 9 to 11 & 11.9 & 17.4 & 34.8 & 7.7 & 14.3 & 44.6 \\
\hline 12 & 24.0 & 16.7 & 20.3 & 26.8 & 21.7 & 26.1 \\
\hline 13 to 15 & 37.5 & 20.5 & 16.7 & 37.9 & 17.6 & 16.8 \\
\hline 16 & 16.4 & 11.0 & 19.7 & 17.7 & 11.2 & 21.7 \\
\hline More than 16 & 7.9 & 5.8 & 21.2 & 8.5 & 5.0 & 20.3 \\
\hline
\end{tabular}

Source: Authors' calculations. Data for 1990 are from the Census Bureau's Public Use Microdata Sample. Data for 1995 are from the Merged Outgoing Rotation Group (MORG) files from the Census Bureau's Current Population Survey (CPS). Throughout the paper, the authors use census and CPS data released in electronic form by the Census Bureau.

a. First two columns under each data set give, for the United States and California, the percentage of native-born persons or immigrants, aged eighteen to sixty-four, who have the given number of years of schooling. Third column under each data set gives the percentage of persons with the given educational attainment who are immigrants. Immigrants are those born abroad who are noncitizens or naturalized citizens. All others are natives.

than nine years of schooling and 68 percent of those with fewer than twelve years of schooling were foreign-born. ${ }^{9}$

Table 3 examines the distribution of immigrants and natives by occupation and industry. The first two columns of data report the percent distribution of native and immigrant workers among occupations and industries nationwide. If immigrants were randomly distributed by occupation and industry, the figures in these two columns would be

9. It is worth emphasizing that the U.S. labor market does not value natives and immigrants with the same educational attainment identically. In fact, the 1990 census indicates that there is roughly a $0.10 \mathrm{log}$ point gap between the earnings of natives and immigrants with the same number of years of schooling. As a result, simple head counts of immigrants will exaggerate their contribution to labor supply. A more accurate picture is obtained by counting immigrants and natives in terms of efficiency units. Below, we calculate the contributions that "equivalent" immigrants make to labor supply. 


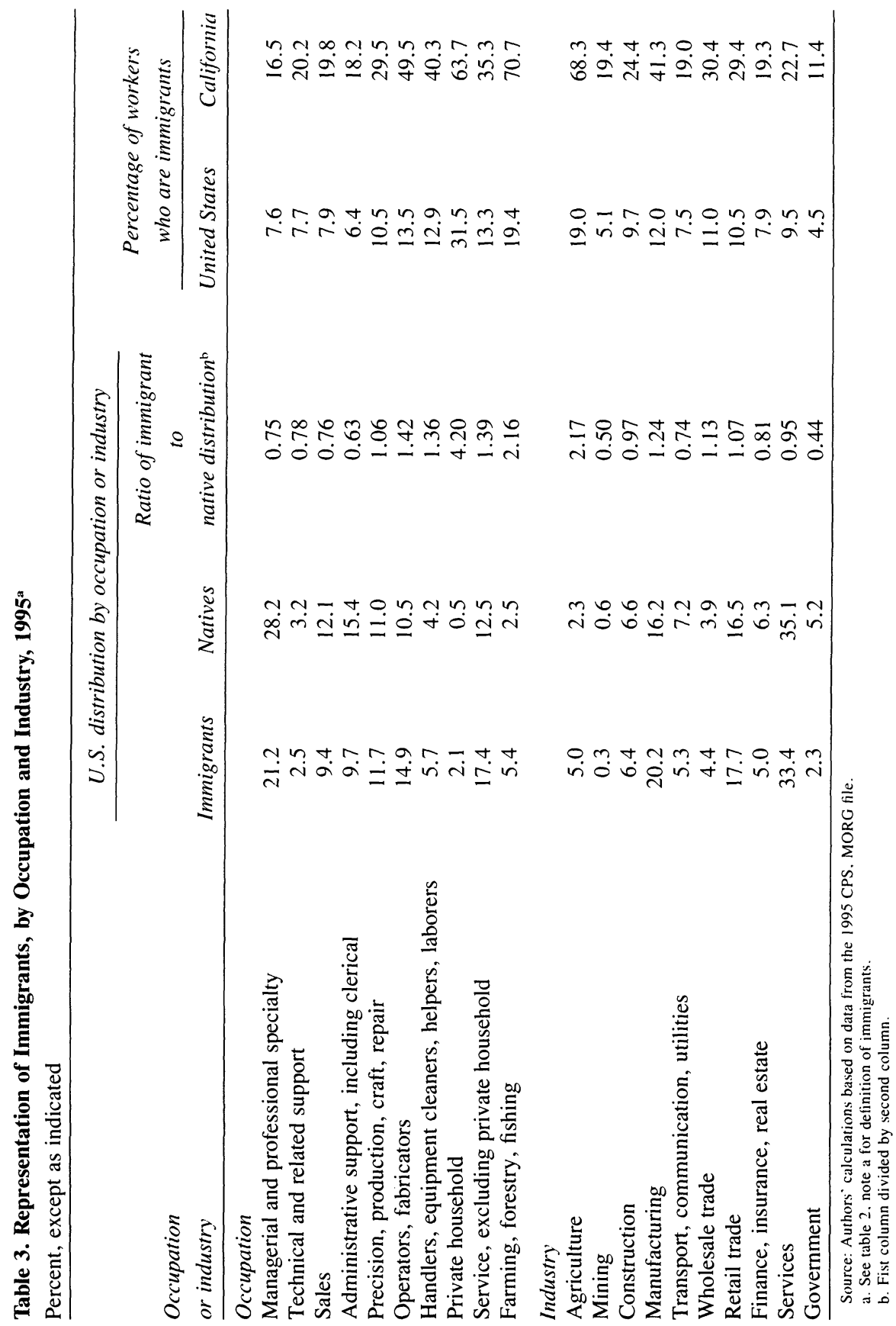


roughly the same. They are not. As the ratios of the immigrant share to the native share in the third column show, immigrants are more concentrated in lower skill occupations than natives and work in a different set of industries. There are relatively more immigrants working in farming occupations, in service jobs, as private household workers, and as operators and fabricators. There are relatively more immigrants in agriculture, in manufacturing, and in wholesale and retail trade. Immigrants are less likely than natives to work in white collar jobs - such as managerial and professional specialties, administrative support, sales and technical support-and are especially underrepresented in government jobs. In part these differences are due to lower educational attainment, but some of them cannot be so easily explained.

The last two columns of table 3 record the proportion of immigrants in different occupations and industries, for the United States and for California. The figures for the entire country provide another way of showing the concentration of immigrants in low-skill occupations and selected industries. The figures for California emphasize the importance of immigration in that state's economy. In some occupations, such as farming, private household, and operators and fabricators, about half or more of California's work force consists of immigrants. In 1995, immigrants made up 68.3 percent of its agricultural work force and 41.3 percent of its manufacturing work force. These numbers suggest that immigration may have affected the industrial structure of California. Between 1970 and 1990, the proportion of workers employed in immigrant-intensive industries fell by only 4.1 percentage points ( 8 percent) in California, as compared with an 8.6 percentage point ( 16 percent) decline in nonimmigrant states, and a 9.4 percentage point (20 percent) decline in the other immigrant-receiving states. ${ }^{10}$ The fraction of California's workers employed in the private household industry fell less than in other states, and the fraction employed in apparel and accessories rose in California but declined elsewhere. To the extent that the industries spurred by immigration compete with similar industries located elsewhere in the country (as might be the case for manufacturing and, possibly, agriculture), the observed change in industry mix pro-

10. We define immigrant-intensive industries as those with a larger share of immigrants than the national average immigrant share of total employment; these comprise personal services (including private household services), agriculture, business and repair services, retail trade, and manufacturing. 
vides yet another potential means by which the effects of immigration are diffused across the country.

Finally, while many immigrants work in manufacturing, many also work in nontraded sectors. The significant immigrant representation in services and retail trade highlights a critical difference between the potential effects of trade and of immigration on native workers. Less skilled natives can escape trade competition with low-paid workers overseas by specializing in the production of nontraded goods; the local sales clerk must live in the United States to deal with customers. Indeed, when no American competes with the Chinese in producing low-cost children's toys, increased imports of those toys benefit even less skilled Americans. But there is no such "cone of diversification" escape that allows native workers to avoid competition from immigrants. Immigrants can just as easily work in nontraded goods and services as in the traded goods sector.

\section{Trade}

The upper panel of figure 2 shows that the most widely used measure of trade, the ratio of exports plus imports to GDP, increased markedly from 1970 to 1980 , stabilized in the 1980s, and has risen since 1990. ${ }^{11}$ While much of the growth in the 1970s was trade between the United States and other advanced countries, the share of imports from LDCs (defined in this figure as all nonindustrial countries, exclusive of the petroleum producing countries) has increased continuously since the 1970s, accelerating in the 1990s. ${ }^{12}$ The bottom panel of figure 2 shows that the ratio of imports from LDCs to U.S. GDP rose from 0.023 in 1980 to 0.028 in 1990 and to 0.041 in 1996 . Nearly 40 percent of U.S.

11. The ratio $(E X+I M) / G D P$ exaggerates the relative magnitude of trade, because $E X$ (exports) and $I M$ (imports) are measured in terms of sales, while GDP is a valueadded concept. Sales are roughly twice GDP, so that a consistent indicator of the magnitude of trade in terms of the traded proportion of sales would be about half of $(E X+I M) / G D P$. Since the ratio of sales to GDP has not changed much over time, the growth of $(E X+I M) / \mathrm{GDP}$ roughly tracks the growth of $(E X+I M) /$ sales.

12. We classify countries on the basis of their level of economic development when the implicit supply shock began, in the 1970s or 1980s. As a result, Japan is classified as an industrial nation, but the four "tigers" (Korea, Singapore, Hong Kong, and Taiwan) are classified as LDCs. On the questions of whether to treat Japan in the 1960s as advanced and whether to treat some of the tigers as advanced economies today, see Sachs and Shatz (1994). 
Figure 2. Growing Openness and LDC Trade, 1970-96a

Ratio
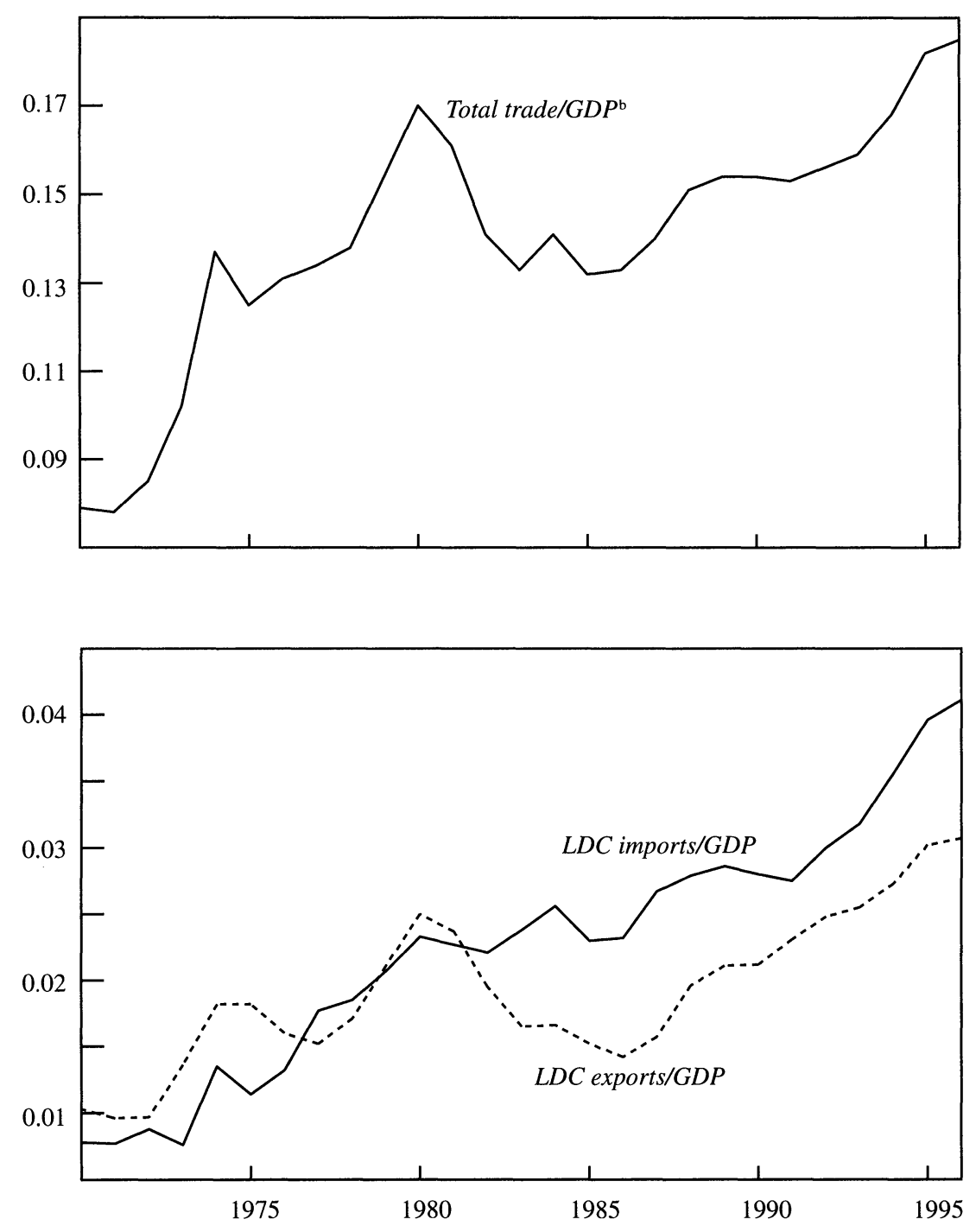

Source: Authors' calculations based on data from the Economic Report of the President, 1997.

a. LDC trade flows include those with trading partners other than Canada, Japan, Australia, New Zealand, South Africa, members of the Organization of Petroleum Exporting Countries, and the countries of western Europe.

b. Exports plus imports divided by GDP. 
imports came from LDCs in 1996, and the largest trade deficit was with China, whose goods made up 6 percent of imports.

The effect of imports and exports on workers depends on the characteristics of workers in those industries affected by trade. If importintensive industries disproportionately use less skilled workers and export-intensive industries disproportionately use more skilled workers, trade will shift the distribution of income from the less skilled to the more skilled. ${ }^{13}$ Table 4 shows how the average characteristics of workers in American manufacturing industries in 1990 differed along trade lines calculated in two different ways. The lines listed as import- or export-weighted averages weight the characteristics of workers in each industry by the ratio of imports (or exports) to sales times the employment in the industry. The lines listed as high export or import intensity are obtained by ranking manufacturing industries by the ratio of exports or imports to sales, and then selecting off the top of the list until 10 percent of the manufacturing labor force is represented. The figures given for LDC import or export intensity are calculated in a similar manner, using LDC imports and exports to weight or categorize industries. For the rest of the economy, we differentiate between agriculture, which is a major exporter, and 'all other' industries: services, trade, and government. Despite the growing international trade in services, the "all other", category can be roughly viewed as the nontraded sector for the purpose of comparison with manufacturing.

The table shows that in the manufacturing sector, the workers most affected by imports are disproportionately immigrants, women, blacks, and the less educated; whereas those most affected by exports are disproportionately native-born, nonblack, and educated men. Moreover, the wages of workers in the top 10 percent of importing industries were $0.53 \mathrm{log}$ point below the wages of those in the top 10 percent of export industries, and the wages of the "average" import worker were 0.15 $\log$ point less than those of the average export worker. Classified by imports and exports with LDCs alone, the skill (wage) composition of the import-affected workers and the skill composition of the exportaffected workers differ even more.

Looking beyond the manufacturing sector, however, the picture is

13. Trefler (1993) discusses the difficulties involved in calculating relative factor proportions. 


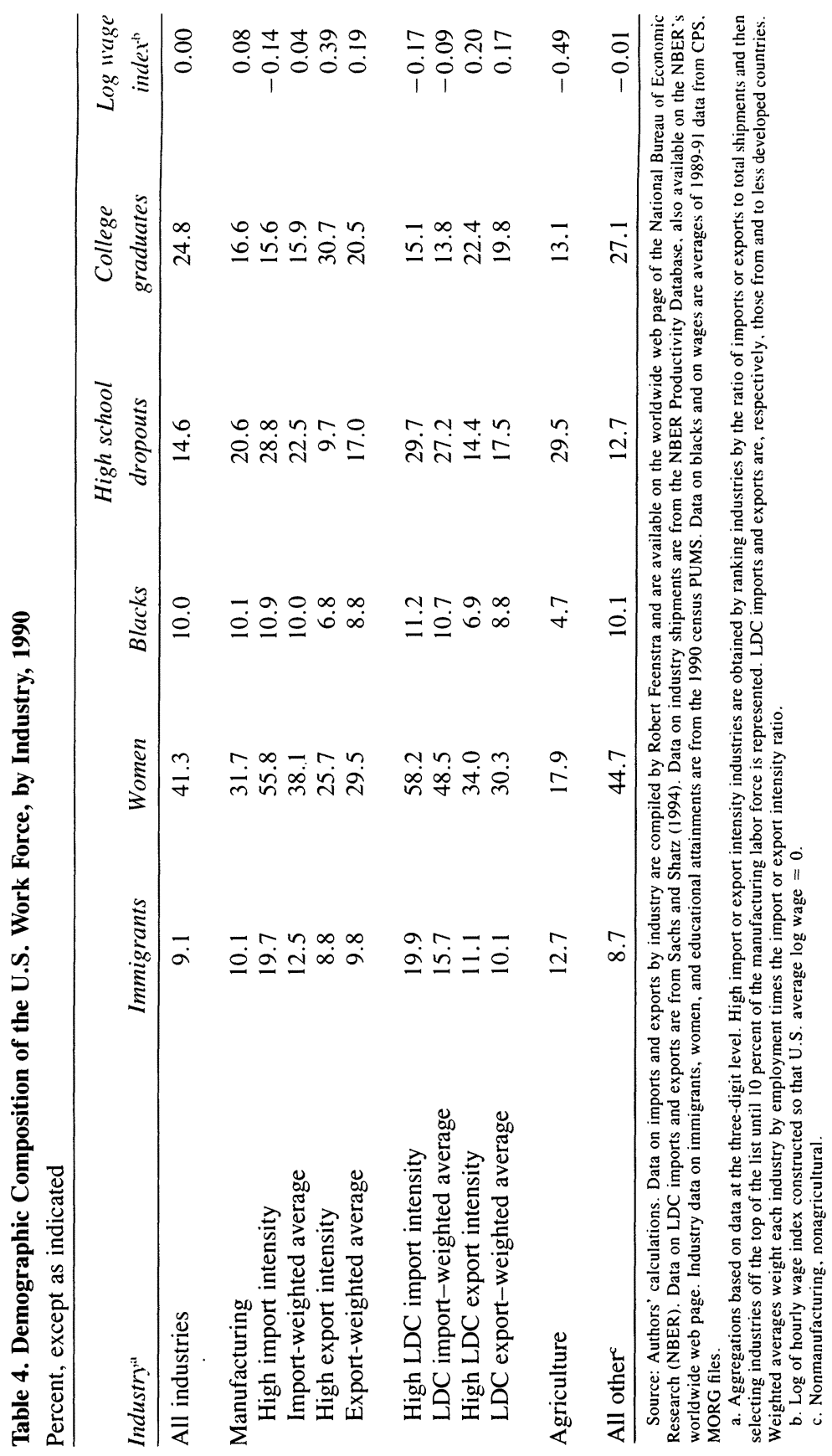


more complex. Agriculture uses low-wage male workers to a greater extent than even the top 10 percent of importing industries in manufacturing. In the heterogeneous " all other' category, the proportion of women exceeds that in the average import sector; and the proportion of college graduates exceeds that in the average export sector. The different composition of the labor force in exporting and importing industries has two implications for trade-based explanations of changes in the U.S. job market. First, the fact that women are disproportionately concentrated in industries that import from LDCs suggests that LDC trade should have affected women more adversely than men. But rates of pay and employment for women have risen since 1970. The evidence thus suggests that there is something wrong with models in which the traded goods sector determines wages for women throughout the economy. The expansion of the "all other" category, which disproportionately employs women, can explain this seeming paradox in a more general model of wage determination. Second, the large and increasing difference between the skill mix of the top and bottom importing and exporting industries raises the possibility that trade may have particular adverse effects on the economic position of some less skilled workers. ${ }^{14}$

\section{The Impact of Immigration: Area Studies}

Suppose (1) that immigrant flows are uncorrelated with economic conditions in an area; and (2) that natives do not alter decisions about location or capital investment in response to immigration. Then comparing native outcomes or changes in outcomes between areas of more immigration and areas of less would offer a good way to isolate the impact of immigration on natives. ${ }^{15}$ Put differently, one knows that immigrants flock to California. Why not just compare labor market

14. While table 4 shows data for 1990 , we have also calculated the equivalent data for 1980; we find that the differentiation between the top 10 percent of import and export sectors increased between 1980 and 1990. One reason for this finding is that LDCs were more dominant in the high-import intensity sectors in 1990 than in 1980. Another is that the automobile industry (a large high-wage industry) was a more significant importer in 1980 than in 1990 .

15. Grossman (1982) represents the first application of this approach. Her finding of a near zero correlation between native wages and immigrant penetration in a local labor market has been confirmed by most studies in this literature. 
outcomes in California to the outcomes observed in the rest of the country?

The problem with contrasting native outcomes between immigrantintensive areas and nonimmigrant areas is that neither proposition 1 nor 2 appears to be valid for the United States. The cities or states where immigrants cluster have done well in some periods and poorly in others, producing a potentially spurious correlation between immigration and area outcomes. For reasons that are probably unrelated to immigration, California is a high-wage state. As a result, immigration will appear to improve native economic opportunities in a cross-section dominated by California. To avoid this spurious cross-sectional spatial correlation, most analysts relate the change in the economic position of natives in an area over time to the change in the number of immigrants. ${ }^{16} \mathrm{Bui}$ a state's economy also fluctuates over time for reasons that are independent of immigration, creating the possibility of spurious longitudinal correlations as well. When California's economy booms, there will be a positive correlation between immigration and the economic position of natives; in a recession, the correlation will be negative. Elsewhere, we report that the time-varying conditions of individual states lead to unstable estimates of immigrant effects on native outcomes. ${ }^{17}$ If one had perfect measures of how economic conditions change within a state and affect relative wages across skill groups, one would be able to control for those conditions and isolate the effect of immigration. Such measures, however, are not available.

Another problem with area analysis is that natives may adjust to the immediate impact of immigration in an area by moving their labor or capital to other localities until native wages and returns to capital are equalized across areas. For example, a large immigrant flow arriving in Los Angeles might well result in fewer unskilled workers from Mississippi or Michigan moving to California and a reallocation of capital from those states to California. A comparison of the wage of less skilled natives between California and other states, therefore, might show little difference because the effects of immigration were diffused around the economy, not because immigration had no economic effects.

16. See, for example, Altonji and Card (1991); LaLonde and Topel (1991), and Schoeni (1996).

17. Borjas, Freeman, and Katz (1996). 


\section{Regional Differences in Native Wages and Employment}

We examine the link between immigration and native outcomes across areas for the periods 1960-70, 1970-80, and 1980-90, using data extracts from the 1960, 1970, 1980, and 1990 Public Use Microdata Samples (PUMS) of the decennial census. The extracts include all persons aged eighteen to sixty-four (as of the census year) who do not live in group quarters. In the 1960 and 1970 censuses, the data extracts are a 1 percent random sample of the population. In 1980 and 1990, the immigrant extracts form a 5 percent random sample and the native extracts form a 1 percent random sample. We define a person as an immigrant if he or she was born abroad and is either a noncitizen or a naturalized citizen; all other persons are classified as natives. Because immigrants are concentrated in particular educational groups, we examine the impact of immigration on the labor market outcomes of natives in five educational categories, or "skill groups": fewer than nine years of schooling, nine to eleven years, twelve years, thirteen to fifteen years, and at least sixteen years.

The labor market is likely to respond to supply shocks with price and quantity adjustments. Our measures of labor market outcomes are log weekly earnings and $\log$ annual earnings from the previous calendar year and the probability of working during the census week. The analysis of the employment probability uses all the observations in our data, while the analysis of weekly or annual earnings uses the subsample of persons who worked for pay at some time in the year preceding the census, were not self-employed, and were working in the civilian sector.

The geographic scope of the labor market in question can affect estimates of the impact of immigration. Studies of a small geographic area are more likely to miss effects of immigration than studies of large areas because native migration and capital responses may diffuse those effects in small areas. We use three alternative definitions of the geographic area: metropolitan areas, states, and census regions. An advantage of using states or regions as the geographic unit is that data at these levels are available for the entire period 1960-90. We limit the analysis of metropolitan areas to the 1980 and 1990 censuses, across which 236 metropolitan areas can be matched. The 1970 census PUMS identifies far fewer metropolitan areas and the 1960 PUMS does not identify any. 
We use age-adjusted measures of labor market outcomes, estimated separately for male and female U.S. natives. We purge our data of age effects in the following way. Let $y_{i j k t}$ be the labor market outcome for person $i$, residing in area $j$, belonging to skill group $k$, in census year $t$; and let $\mathbf{Z}_{i j k t}$ be a vector of dummy variables indicating whether the worker is aged eighteen to twenty-four, twenty-five to thirty-four, thirty-five to forty-four, forty-five to fifty-four, or fifty-five to sixtyfour. Finally, let $r_{j k t}$ be a fixed effect giving the age-adjusted "average" labor market outcome experienced by a native who lives in area $j$ and belongs to skill group $k$ in year $t$. We then estimate the following regression separately for each native group based on sex and education in each census year:

$$
y_{i j k t}=\mathbf{Z}_{i j k t} \boldsymbol{\beta}_{k t}+r_{j k t}+u_{i j k t},
$$

where $u_{i j k t}$ is the error term, assumed uncorrelated with the independent variables in the model. The age-adjusted measures of outcomes are given by the fixed effects $r$, evaluated at the mean age distribution of the native sample from the pooled 1970, 1980, and 1990 censuses.

We use the estimated fixed effects $r$ to calculate first difference estimates of changes in the labor market outcome for each sex-education group. We define the change in outcome for a particular sex-education group in a particular region as

$$
\Delta r_{j k t}=r_{j k t}-r_{j, k, t-10} .
$$

Table 5 summarizes the key patterns in our data, in terms of regression coefficients linking changes in wages or immigration from one decade to the next. The first and third rows report the results of regressing the change in age-adjusted log weekly earnings in the 1980s for a state-education cell on the change in log weekly earnings in the 1970s for the same state-education cell. ${ }^{18}$ The regression includes a vector of education fixed effects; by including these, we isolate the secular correlation in wage growth within an educational group. The results reveal a strong negative relation in wage growth by state between the two periods. The coefficient in the male regression is -1 , implying a complete reversal in the ranking of states by wage growth between the 1970s

18. The wage growth regressions are weighted by $\left(n_{x} n_{y}\right) /\left(n_{x}+n_{y}\right)$, where $n_{t}$ gives the sample size in year $t$, and $x$ and $y$ are the years spanned by the period defining the dependent variable. 
Table 5. State Cross-Section Autoregressions Estimating Changes in Native Earnings Growth and Immigrant Flows between Census Decades ${ }^{\mathrm{a}}$

\begin{tabular}{lllcc}
\hline Sample & \multicolumn{1}{c}{$\begin{array}{c}\text { Dependent } \\
\text { variable }\end{array}$} & \multicolumn{1}{c}{$\begin{array}{c}\text { Independent } \\
\text { variable }\end{array}$} & Coefficient & $R^{2}$ \\
\hline Males & Wage growth, 1980-90 & Wage growth, 1970-80 & -1.052 & 0.640 \\
& Wage growth, 1970-80 & Wage growth, 1960-70 & 0.002 & 0.149 \\
& & & $(0.084)$ & \\
Females & Wage growth, 1980-90 & Wage growth, 1970-80 & -0.591 & 0.438 \\
& Wage growth, 1970-80 & Wage growth, 1960-70 & $(0.073)$ & \\
& & & 0.179 & 0.456 \\
& Immigrant supply & Immigrant supply & 1.498 & 0.753 \\
All persons & change, 1970-80 & $(0.054)$ & \\
& change, 1980-90 & Immigrant supply & 1.251 & 0.500 \\
& Immigrant supply & change, 1960-70 & $(0.098)$ & \\
\hline
\end{tabular}

Source: Authors' calculations based on data from the census PUMS (various years)

a. Wage growth is defined as the log change in age-adjusted weekly earnings: $r_{j k t}-r_{j . k . t-10}$, from equation 2 in the text, where $j$ represents one of the fifty states or the District of Columbia and $k$ represents one of the five skill groups described in the text. Change in the immigrant supply, from equation 3 in the text, is $\left(M_{j k t}-M_{j, k, t-10}\right) / N_{j, k, t-10}$, where $M_{j k}$ and $N_{j k}$ are the number of immigrants and natives, respectively, in the given state and skill group. Regressions include fixed effects identifying each skill group. Standard errors are shown in parentheses. Each regression contains 255 observations.

and the 1980s. Figure 3, which compares rates of growth of wages by state in the census data, illustrates this striking pattern. ${ }^{19}$

When we obtained this result, we initially wondered if it might largely reflect measurement error; the log of the 1980 weekly wage enters each side of the regression equation with opposite sign. This is not the case. We estimate an analogous regression using 1970-80 wage growth as the dependent variable and 1960-70 wage growth as the independent variable. This regression, reported in the second and fourth rows of table 5 and illustrated in figure 3 , shows no correlation in wage growth for men between the two decades and a positive correlation for women. ${ }^{20} \mathrm{We}$ next wondered whether the result was due to some pe-

19. The figure "aggregates"' the data across skill groups in a state by weighting the wages of workers with different levels of schooling by the national proportion of workers in each educational group.

20. Although the regional structure of wage growth changed over the period, the correlation matrix in wage levels indicates that these are strongly and positively correlated over time. Every single element in the wage level correlation matrix, for both men and women, over the period 1960-90 exceeds 0.91 , where the matrix of correlation coefficients is weighted by the sample size in the state-education cell in the 1990 census. 
Figure 3. The Changing Regional Wage Structure ${ }^{a}$

Change in log earnings, 1980-90

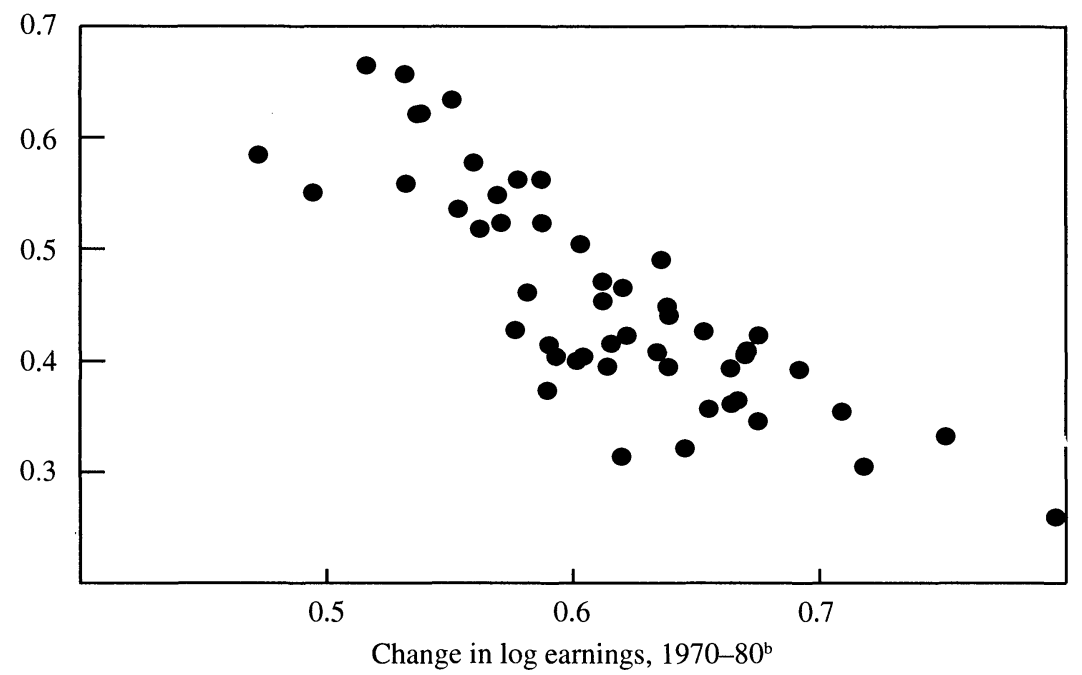

Change in log earnings, $1970-80^{\mathrm{b}}$

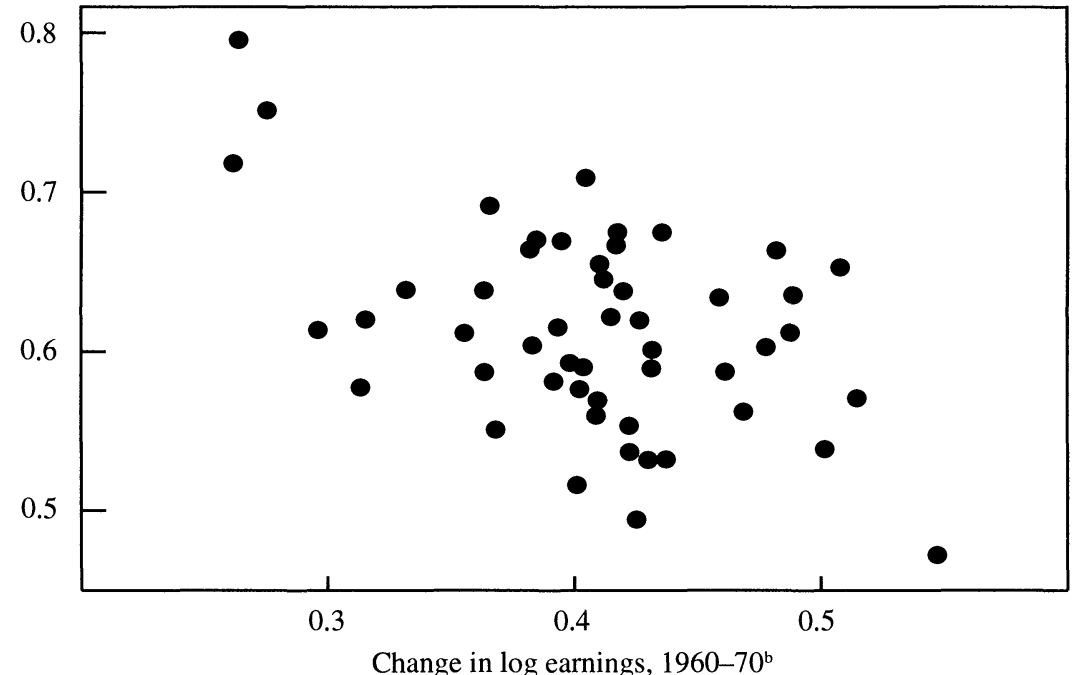

Source: Authors' calculations based on data from the census PUMS (various years).

a. Each plotted point represents one of the fifty states or the District of Columbia.

b. $\Delta$ ln weekly earnings of natives aged eighteen to sixty-four. 
culiarity in the census data. However, we reestimated these regressions using establishment data on average log weekly wages for workers covered by each state's unemployment insurance system and again found a strong negative correlation between wage growth by state in the 1970s and in the 1980s.

The fact that the high-wage growth states of the 1970s became lowwage growth states in the 1980 s has a crucial implication for any analysis that exploits spatial differences to infer the effects of immigration on native outcomes. Since the states that received large numbers of immigrants in the 1970s also received large numbers of immigrants in the 1980s, the reversal of wage growth among states implies a reversal in the sign of the correlation between changes in wages and in immigration by state. As a result, one's inferences about the impact of immigration will almost certainly differ according to the period analyzed.

Formally, let $M_{j k t}$ be the number of immigrants (both male and female) who live in region $j$ and belong to skill group $k$ in census year $t$, and let $N_{j k t}$ be the number of (male and female) natives in that region and skill group. We define the change in labor supply due to immigration during the decade that ends in year $t$ as

$$
\Delta m_{j k t}=\frac{M_{j k t}-M_{j, k, t-10}}{N_{j, k, t-10}} .
$$

The fifth row of table 5 reports the results of regressing the change in the immigrant supply over 1980-90 on the change in the immigrant supply over 1970-80, including a vector of education fixed effects to isolate changes within educational groups. The regression shows a strong positive correlation between the growth of immigrants in a state in the 1970s and the growth of immigrants in that state in the 1980s. In the sixth row, we lag the regression by one decade; the correlation in supply shocks between the 1960 s and the 1970 s is also positive and is almost as strong.

The data thus indicate that immigration induced large supply shocks in the same states in the 1970s and in the 1980s. But they also show that the states that experienced high wage growth in the 1970s experienced low wage growth in the 1980s. The result is a reversal in the sign of the correlation between changes in immigration by state and changes in wages. The correlation between $\Delta m$ and $\Delta r$ by state switches from -0.19 in $1970-80$ to 0.34 in $1980-90$ for men, and from -0.18 to 
0.44 for women. Studies that calculate spatial correlations between wage growth and immigrant supply shocks will not be able to obtain consistently negative or positive effects across different censuses unless they can control for the forces that caused the regional wage structure to change so dramatically over time. These unobserved structural forces are so strong that a consistent impact of immigration, if such exists, probably cannot be detected in an analysis of interarea differences.

In view of this observation, it is not surprising that our analysis of regional differences in wage trends show little systematic evidence that the immigrant supply shock had an impact on the weekly earnings of natives. For simplicity, we divide the country into three regions: California, the other five states that receive large numbers of immigrants (New York, Texas, Florida, New Jersey, and Illinois), and the remainder of the country.

Table 6 reports log weekly earnings in each of these regions for natives in each educational group relative to natives with exactly twelve years of education in the given region, from 1960 to $1990 .{ }^{21}$ For almost every educational group, the pattern of wage differentials moves similarly in California, the other immigrant-receiving states, and the nonimmigrant states. Consider, for example, native men who have between nine and eleven years of schooling. In 1990, this group made up 14.0 percent of native adults. Native men in this educational group who lived in California earned 0.08 log point less than natives with a high school diploma in 1960 and 0.19 log point less in 1990. Their counterparts in the other immigrant-receiving states earned $0.12 \mathrm{log}$ point less than natives with a high school diploma in 1960 and $0.24 \mathrm{log}$ point less in 1990. The trend in the relative wage of this skill group was similar in the states that had few immigrants: -0.13 log point in 1960 and $-0.24 \log$ point in 1990 . Thus from 1960 to 1990 , the relative wage of this less skilled group of native men declined by about 0.11 log point in each of the regions, even though the immigrant shock to California was disproportionately less skilled. The natural "differencein-difference"' estimate of the immigrant wage effect-the wage growth of California's natives less the wage growth of natives in the nonimmigrant states-suggests that immigration did not affect native wage

21. The fixed effects for the aggregated regions are obtained by "adding up" $r_{j k i}$ over the states in the region, with each state's observation weighted by the number of working natives in that state in the given census year. 
Table 6. Relative Log Weekly Earnings of Natives by Skill Group, 1960-90

Log index ${ }^{a}$

\begin{tabular}{|c|c|c|c|c|c|c|c|}
\hline \multirow[b]{2}{*}{$\begin{array}{l}\text { Years of } \\
\text { schooling }\end{array}$} & \multirow[b]{2}{*}{ Year } & \multicolumn{3}{|c|}{ Males } & \multicolumn{3}{|c|}{ Females } \\
\hline & & California & $\begin{array}{c}\text { Other } \\
\text { immigrant } \\
\text { states }^{\mathrm{b}}\end{array}$ & $\begin{array}{l}\text { Other } \\
\text { states }\end{array}$ & California & $\begin{array}{c}\text { Other } \\
\text { immigrant } \\
\text { states }^{\mathrm{b}}\end{array}$ & $\begin{array}{l}\text { Other } \\
\text { states }\end{array}$ \\
\hline Fewer than 9 & $\begin{array}{l}1960 \\
1970 \\
1980 \\
1990\end{array}$ & $\begin{array}{l}-0.215 \\
-0.193 \\
-0.194 \\
-0.331\end{array}$ & $\begin{array}{l}-0.344 \\
-0.345 \\
-0.359 \\
-0.366\end{array}$ & $\begin{array}{l}-0.383 \\
-0.359 \\
-0.361 \\
-0.343\end{array}$ & $\begin{array}{l}-0.357 \\
-0.336 \\
-0.163 \\
-0.208\end{array}$ & $\begin{array}{l}-0.395 \\
-0.331 \\
-0.271 \\
-0.374\end{array}$ & $\begin{array}{l}-0.510 \\
-0.384 \\
-0.268 \\
-0.285\end{array}$ \\
\hline 9 to 11 & $\begin{array}{l}1960 \\
1970 \\
1980 \\
1990\end{array}$ & $\begin{array}{l}-0.084 \\
-0.111 \\
-0.176 \\
-0.187\end{array}$ & $\begin{array}{l}-0.120 \\
-0.175 \\
-0.212 \\
-0.235\end{array}$ & $\begin{array}{l}-0.128 \\
-0.175 \\
-0.219 \\
-0.239\end{array}$ & $\begin{array}{l}-0.196 \\
-0.208 \\
-0.207 \\
-0.215\end{array}$ & $\begin{array}{l}-0.216 \\
-0.220 \\
-0.204 \\
-0.239\end{array}$ & $\begin{array}{l}-0.247 \\
-0.220 \\
-0.186 \\
-0.218\end{array}$ \\
\hline 13 to 15 & $\begin{array}{l}1960 \\
1970 \\
1980 \\
1990\end{array}$ & $\begin{array}{l}0.059 \\
0.061 \\
0.052 \\
0.089\end{array}$ & $\begin{array}{l}0.081 \\
0.081 \\
0.062 \\
0.100\end{array}$ & $\begin{array}{l}0.085 \\
0.077 \\
0.046 \\
0.083\end{array}$ & $\begin{array}{l}0.043 \\
0.091 \\
0.068 \\
0.127\end{array}$ & $\begin{array}{l}0.115 \\
0.134 \\
0.113 \\
0.153\end{array}$ & $\begin{array}{l}0.129 \\
0.112 \\
0.097 \\
0.156\end{array}$ \\
\hline 16 or more & $\begin{array}{l}1960 \\
1970 \\
1980 \\
1990\end{array}$ & $\begin{array}{l}0.271 \\
0.313 \\
0.280 \\
0.414\end{array}$ & $\begin{array}{l}0.308 \\
0.374 \\
0.322 \\
0.463\end{array}$ & $\begin{array}{l}0.305 \\
0.334 \\
0.262 \\
0.410\end{array}$ & $\begin{array}{l}0.439 \\
0.500 \\
0.362 \\
0.513\end{array}$ & $\begin{array}{l}0.510 \\
0.565 \\
0.446 \\
0.579\end{array}$ & $\begin{array}{l}0.544 \\
0.589 \\
0.428 \\
0.558\end{array}$ \\
\hline
\end{tabular}

Source: Authors' calculations based on data from the census PUMS (various years).

a. Log of index constructed so that log earnings of natives with exactly twelve years of schooling $=0$ in each sample year and region.

b. New York. New Jersey, Illinois, Florida, and Texas.

differentials. The one exception to this pattern is native men who have less than nine years of schooling, which is an extremely small group.

The raw data thus suggest that it is extremely difficult to obtain consistent estimates of the labor market effects of immigration from spatial correlations. Our efforts to find such effects support this inference. Consider the regression model

$$
\Delta r_{j k t}=\alpha_{t}+\beta_{t} \Delta m_{j k t}+v_{j}+\tau_{k}+u_{j k t},
$$

where $v_{j}$ is a fixed effect indicating the group's area of residence and $\tau_{k}$ is a fixed effect indicating the group's educational attainment. The education fixed effects net out any change occurring in the national market for workers with that level of education, while the area fixed effects net out the impact of the level of state economic activity on all natives residing in that state. They represent our best effort to control 
for factors unrelated to immigration that might affect outcomes across groups and states.

We measure the immigration supply shock as the change in the size of the immigrant population relative to the native population at the beginning of the decade (see equation 3 ). This measure differs from the first difference in the foreign-born share of the work force that is used in many area studies of immigration. It avoids the potential endogeneity of the immigration variable due to the possibility that the native population at the end of the decade depends on immigration, and also the potential endogeneity of labor force participation (of both immigrants and natives) to the immigrant supply shock. ${ }^{22}$ Finally, we use the supply shock in the specific educational group as the measure of immigrant penetration. This variable helps us to better capture the "own" effects in the data. ${ }^{23}$

Table 7 presents our estimates of the coefficient $\beta_{t}$ from the 1960-90 census data. There is a great deal of variation in the estimated coefficients by scope of geographic area, sex, and time period, making it difficult to draw any robust generalization about the effects of immigration on labor market outcomes. ${ }^{24}$ Consider, for example, the relationship between immigration and the employment probability for native men. The regression coefficients for the 1980 s suggest that immigrant supply shocks lead to lower employment for native workers, and that this effect becomes more negative, the greater the scope of the geographic area. At the regional level, the regressions suggest that a 10 percentage point increase in the relative number of immigrants re-

22. We replicated the regression analysis using counts of workers, with little change in the underlying results?

23. Although it seems as if the specification in equation 4 ignores cross-effects between various types of immigrant workers and natives, the regressions do include area fixed effects. These fixed effects partly control for the supply shock attributable to the total immigrant flow into an area. We also experimented with alternative specifications of the regressions that allowed for an "own effect" as well as some cross-effects. However, the correlation between the own supply shock and the total supply shock is typically above 0.7 , so that the data do not allow a reliable estimation of a more general model.

24. In Borjas, Freeman, and Katz (1996) we note that analysis of native wage growth in the 1980s shows that the spatial correlation became more negative as the geographic area under consideration was expanded. Table 7 , however, indicates that the negative correlation between the regression coefficients and the scope of the geographic area disappears in earlier decades, in particular, in the 1960s. 


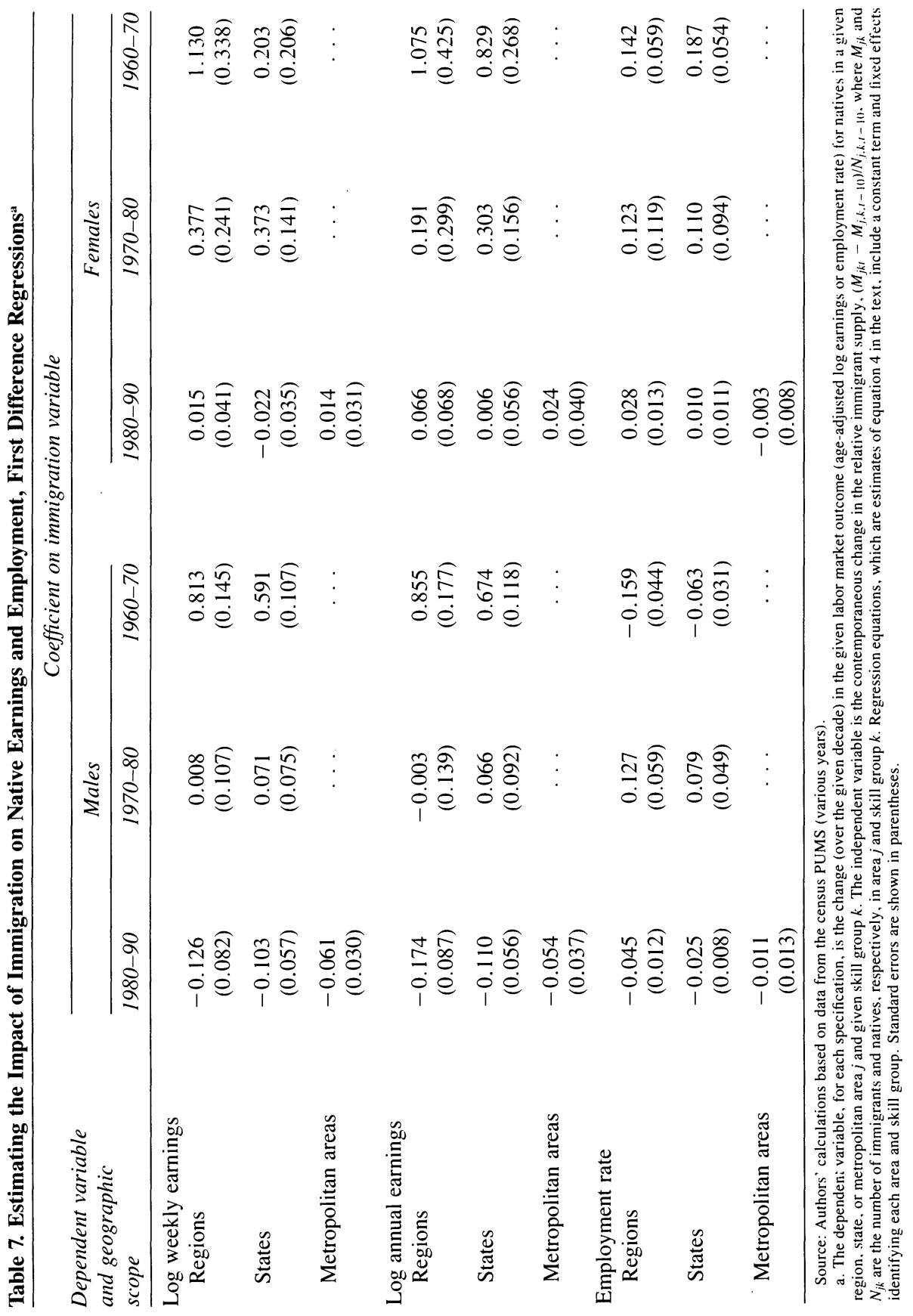


duces the employment-to-population ratio of natives by about 0.45 percentage point. But this coefficient is implausibly large and positive in the 1970s and implausibly large and negative in the 1960s. The data also reveal little consistency in the results for weekly and annual earnings, or for men and women.

One way to interpret the inconsistent spatial correlations between changes in native outcomes and immigration over the period 1960-90 is that the economic impact of immigration on native labor market outcomes simply changes over time or differs by sex. That is, we have the "right" estimates, but they vary a great deal. We do not believe that this is so. If it were, the historical record would provide virtually no information about the future effects of immigration or of changes in immigration policy on native outcomes.

Our interpretation of the results in table 7 is that the spatial correlation between changes in native outcomes and immigration do not, in fact, measure what we want them to measure. The inconsistency in the signs of the correlations over time provides little information about the structural impact of immigration on the native labor market. Our finding that the pattern of regional wage changes has shifted dramatically over time-while the same regions keep receiving immigrants-suggests that unobserved factors are driving the evolution of the regional wage structure, that these factors have little to do with immigration, and that they dominate the data. The one valid inference from an analysis of spatial correlations is that immigration is not a major determinant of the regional structure of labor market outcomes for natives.

\section{Immigration and Native Internal Migration}

The fact that immigration is not consistently related to regional labor market outcomes for natives raises the question of why immigration effects are so weak at the regional level, despite the striking geographic clustering of immigrants. One hypothesis is that the immigration effect is diffused through the internal migration flows of native workers or capital. Previous research has focused on labor flows, without reaching a clear consensus of findings. Some studies find that metropolitan areas where immigrants cluster had lower rates of native in-migration and higher rates of native out-migration in the 1970s. ${ }^{25}$ David Card reports

25. See, for example, Filer (1992) and White and Hunter (1993). 
that the unexpected arrival of 120,000 Marielitos in Miami in 1980 did not raise the city's population growth over the next five years relative to demographic predictions made before the Mariel boatlift. ${ }^{26}$ Consistent with these studies, William Frey and Kao-Lee Liaw find a strong negative correlation between immigration and the net migration rates of natives in the 1990 census. ${ }^{27}$ By contrast, in a later study Card reports a slight positive correlation between the rate of growth in the number of native workers and the rate of growth in the number of immigrant workers by metropolitan area, over the period 1985-90..$^{28}$ Therefore it remains in question whether native internal migration is an important mechanism for diffusing the effects of immigration nationwide.

We address this issue by examining the population trends of natives and immigrants aged eighteen to sixty-four, by state, using decennial census data from 1950 to $1990 .{ }^{29}$ We analyze data at the state level because the state of residence is the one measure of native location decisions that is available in each of these data sets. As with wage outcomes, it is instructive to compare population trends in California, other immigrant-receiving states, and nonimmigrant states. Table 8 reports the proportions of the total population, of natives, and of immigrants living in these areas from 1950 to 1990. As shown above, large-scale immigration to the United States resumed around 1970 and has continued since. Hence by contrasting changes in the residential location of the native population before and after 1970, one can assess the effects of immigration on native location decisions. ${ }^{30}$ The period of analysis thus spans both the preimmigration pattern of internal migration (the "pretreatment period") and the postimmigration adjustments (the "treatment period").

The data reveal one important fact: up to 1970, the share of natives who lived in the major immigrant-receiving state, California, was rising rapidly; since 1970, the share of natives living in California has barely changed. Between 1950 and 1970 the fraction of natives who lived in California rose by 2.7 percentage points (39 percent): between 1950

26. Card (1990).

27. Frey (1995a, 1995b); Frey and Liaw (1996).

28. Card (1997).

29. We use the sample of persons who do not reside in group quarters.

30. The data clearly indicate that the migration patterns of the U.S. population (as opposed to cross-state differences in fertility and death rates) dominate shifts in population across states; see Blanchard and Katz (1992). 


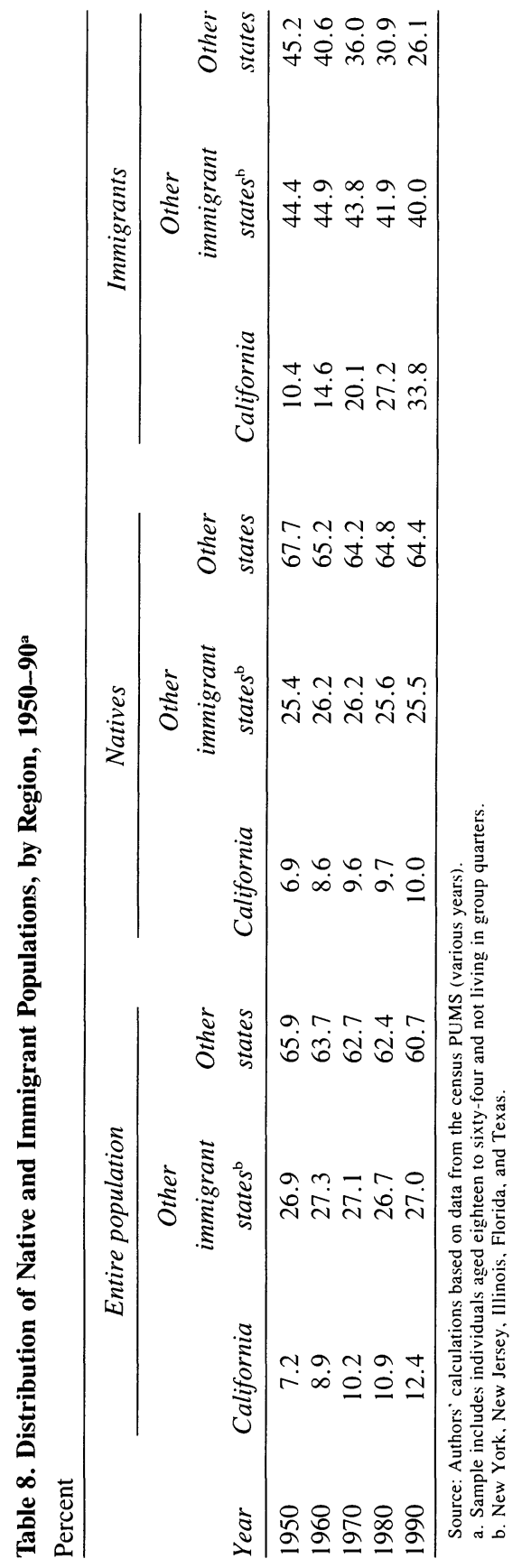


and 1960 it increased from 6.9 to 8.6 percent and between 1960 and 1970 it increased from 8.6 to 9.6 percent. In contrast, the fraction of natives living in California rose by only 0.1 percentage point from 1970 to 1980 and by just 0.3 point from 1980 to 1990 , a cumulative increase of 0.4 point ( 4.2 percent).

If California's share of the total U.S. population had also stabilized between 1970 and 1990, one would perhaps conclude that the state had reached some equilibrium steady-state share of the population. But California's share rose from 10.2 percent in 1970 to 12.4 percent in 1990: a 2.2 percentage point ( 22 percent) increase. In fact, California shifted from growth based on native migration to growth based on immigrants. If the share of the native population in California had increased in the 1970s and 1980s at the same rate as in the 1950s and 1960s, 12.3 percent of natives would have lived in California in $1990 .^{31}$ An extrapolation of the pre-1970 demographic trends-that is, before the immigrant supply shock-accurately predicts the state's share of the entire U.S. population in $1990 .{ }^{32}$ Figure 4 shows that the data point for California (like the points for each of the other immigrant-receiving states) lies close to the regression line linking the population growth rate in 1970-90 to that in 1950-70. This finding suggests that the increasing number of immigrants who chose to settle in California displaced the native net migration that would otherwise have occurred and thus diffused the economic effects of immigration from California to the rest of the country.

We formalize this insight with a simple regression model. We define the simple annualized population growth rate contributions for natives, $\Delta n_{j}\left(t, t^{\prime}\right)$, and immigrants, $\Delta m_{j}\left(t, t^{\prime}\right)$, as

$$
\Delta n_{j}\left(t, t^{\prime}\right)=\frac{N_{j t^{\prime}}-N_{j t}}{L_{j t}} \div\left(t^{\prime}-t\right)
$$

and

31. Extrapolating the trend over $1950-70$ to this later period implies that the native share would have grown by 2.7 percentage points between 1970 and 1990 . Admittedly, this simple exercise assumes away the nonlinearities that may exist in the rate of change in California's population share.

32. Evidence provided by Blanchard and Katz (1992) presages this finding: their figure 1 shows that California lies on the regression line linking the rate of employment growth in 1970-90 to that in 1950-70. 


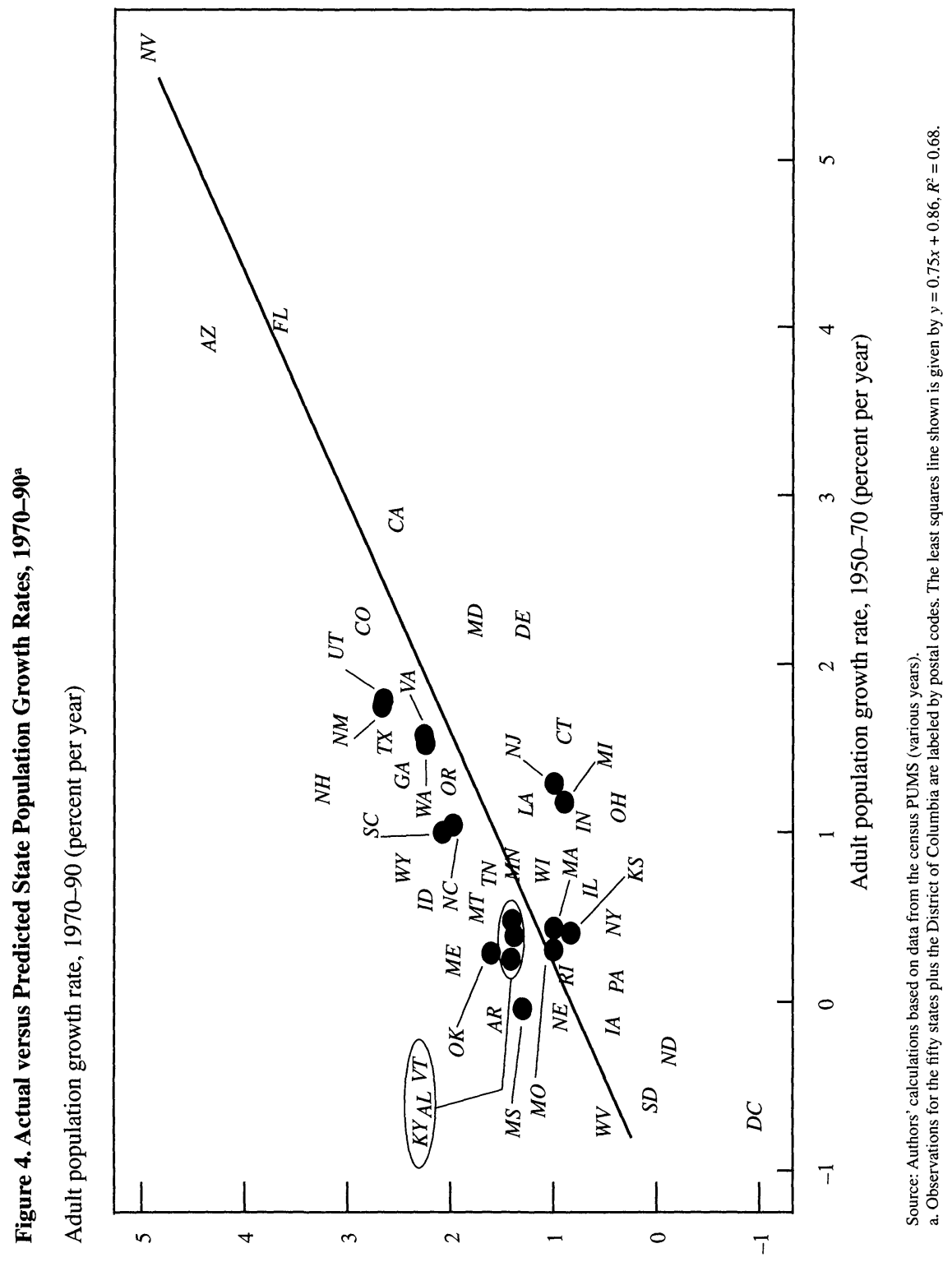


Table 9. Estimating the Response of State Native Population Flows to State Immigrant Population Flows ${ }^{\text {a }}$

\begin{tabular}{lcc}
\hline & \multicolumn{2}{c}{ Double differences } \\
\cline { 2 - 3 } First differences, & $1970-90$ & $1970-90$ \\
$1970-90$ & minus & minus \\
\hline 0.777 & $1960-70$ & $1950-70$ \\
$(0.311)$ & -0.756 & -1.673 \\
& $(0.278)$ & $(0.285)$ \\
\hline
\end{tabular}

Source: Authors' calculations based on data from the census PUMS (various years)

a. For first differences specification, dependent variable is the average annual contribution of native population growth to overall population growth in each state: independent variable is the contribution of immigrant population growth. For double difference specifications, the changes in these average annual contributions (between periods given) are used as variables. For details, see equations 7 (first differences) and 8 (double differences) in the text. Sample comprises the fifty states plus the District of Columbia, except for the final column, which excludes Alaska and Hawaii. Standard errors are shown in parentheses

$$
\Delta m_{j}\left(t, t^{\prime}\right)=\frac{M_{j t^{\prime}}-M_{j t}}{L_{j t}} \div\left(t^{\prime}-t\right),
$$

where $N_{j t}$ gives the number of natives living in state $j$ in year $t, M_{j t}$ gives the respective number of immigrants, and $L_{j t}=N_{j t}+M_{j t}$. We then estimate the following first difference regression model:

$$
\Delta n_{j}(70,90)=a+b \Delta m_{j}(70,90)+e_{j},
$$

where " 70 " and " 90 " indicate the census years 1970 and 1990, respectively, and $e_{j}$ is the stochastic error. This regression links the annual growth rate of natives in a state to the growth rate of immigrants in that state, both relative to the state's total population in the base year, 1970 . Because the dependent and independent variables are scaled by the same factor, the coefficient $b$ measures the impact of an additional immigrant arriving in the state between 1970 and 1990 on the change in the number of natives living in that state during that period.

The sample contains fifty-one observations (for each state plus the District of Columbia). The first column in table 9 reports the estimated coefficient $b .^{33}$ The data reveal a positive and significant relation between immigration by state and change in the size of the native population. Does this positive coefficient imply that natives do not respond to immigration in their location decisions, or perhaps even respond by

33. All the first difference models estimated in this section are weighted by the factor $\left(n_{x} n_{y}\right) /\left(n_{x}+n_{y}\right)$, where $n_{t}$ gives the sample size in year $t$, and $x$ and $y$ are the years spanned by the period defining the dependent variable. We also estimated the models separately for men and women, with little change in the results. 
moving to areas penetrated by immigrants? How can one reconcile these results with the fact that native migration to the major immigrantreceiving state, California, effectively ended around 1970?

The key difference between the regression model in equation 7 and our earlier tabulations is that the first difference regression compares population growth among states with different levels of immigration in 1970-90, rather than native migration in a given state before and after the immigrant supply shock. The regression estimated in the first column of table 9 implicitly assumes that each state would have had the same rate of native population growth in the absence of immigration, so that California and Vermont were on the same population growth path. But if each state had its own growth path prior to immigration, and that growth path would have continued absent immigration, the regression gives a misleading inference about the effects of immigration. To isolate the impact of immigration on the net migration of native workers, one needs a difference-in-difference comparison of how a given state's population grows before and after the immigrant supply shock. The following double difference model provides such a comparison:

$$
\begin{aligned}
& \Delta n_{j}(70,90)-\Delta n_{j}(60,70) \\
&=\alpha+\beta\left[\Delta m_{j}(70,90)-\Delta m_{j}(60,70)\right]+v_{j},
\end{aligned}
$$

where the coefficient $\beta$ measures the impact of an increase in the number of immigrants on the number of natives, relative to the "preexisting conditions" in the state. A useful interpretation of the double difference in equation 8 is that it imposes a particular structure on the state's fixed effect-the rate of population growth that the state was experiencing before the immigrant supply shock.

The second column of table 9 reports the coefficient from the double difference model, using the state's population growth from 1960 to 1970 as the counterfactual control. ${ }^{34}$ Controlling for the state's pre1970 population growth path changes the sign of the effect of immigration on native net migration from positive to negative. In fact, the estimated $\beta$ suggests considerable displacement (the coefficient is not significantly different from -1 ).

34. The double difference models are weighted by $\left(n_{x} n_{y} n_{z}\right) /\left(n_{y} n_{z}+4 n_{x} n_{z}+n_{x} n_{y}\right)$, where $n$, gives the sample size in year $t, x$ and $z$ are the years that span the period defining the dependent variable (with $z>y>x$ ). 
The regression coefficient presented in the second column essentially reiterates the descriptive results presented in table 8 . The negative coefficient reflects the facts that California experienced the largest immigrant supply shock and that its native population share stopped growing when the supply shock began. The third column of the table reestimates the double difference model using the annualized population growth rate over 1950-70 to control for conditions in the state before the immigrant supply shock. This regression yields an even more negative coefficient-indeed, it seems too negative, because it is larger than one in absolute value. This "excess sensitivity" is probably a functional form issue. It is unclear whether, in the absence of an immigration shock, California's share of the native population would have grown at the rapid rate of 1.4 percentage points per decade that prevailed over 1950-70. The only term in the regression that would capture this possible nonlinearity is the change in the rate of growth of the immigrant population.

Table 9 demonstrates that the sign of the impact of immigration on the growth of the native population depends critically on the counterfactual implicit or explicit in a particular regression model. While the data support the inclusion of a lagged native population growth rate in the model linking native net migration to immigration, this is not the reason why we prefer this model. ${ }^{35}$ Selection of a model depends not simply on statistical results, but on the economic relevance of the counterfactual that it poses. We contrast native growth rates before and after the immigrant supply shock because this comparison may provide a plausible answer to the question of what would have happened to the native population if immigration had remained at pre-1970 levels; that is, the growth path that would have been observed if the immigrant supply shock had never occurred.

35. The double difference regression in equation 8 imposes two restrictions on the coefficients. In particular, the coefficient on the 1960-70 native growth rate is unity and the coefficient of the 1960-70 immigrant growth rate is equal, but of opposite sign, to the coefficient on the 1970-90 immigrant growth rate. The unrestricted regression is

$$
\begin{aligned}
\Delta n_{j}(70,90)= & 0.988 \Delta n_{j}(60,70)-1.218 \Delta m_{j}(70,90)+3.310 \Delta m_{j}(60,70), \\
& (0.167)
\end{aligned}
$$

where the regression includes a constant term and standard errors are in parentheses. The restriction on the native coefficient is satisfied by the data, whereas the restriction on the immigrant coefficients is rejected (with a $t$ statistic of 2.68). 
Table 10. Distribution of Regional Adult Populations by Educational Attainment, 1950-90a

Percent

\begin{tabular}{|c|c|c|c|c|c|}
\hline \multirow[b]{2}{*}{ Region and year } & \multicolumn{5}{|c|}{ Years of schooling } \\
\hline & Fewer than 9 & 9 to 11 & 12 & 13 to 15 & 16 or more \\
\hline \multicolumn{6}{|l|}{ California } \\
\hline 1950 & 26.8 & 20.5 & 31.8 & 13.2 & 7.7 \\
\hline 1960 & 20.9 & 21.8 & 32.6 & 15.0 & 9.7 \\
\hline 1970 & 12.5 & 17.8 & 36.6 & 19.9 & 13.2 \\
\hline 1980 & 9.6 & 13.2 & 34.2 & 24.8 & 18.3 \\
\hline 1990 & 9.3 & 13.4 & 22.0 & 33.0 & 22.3 \\
\hline \multicolumn{6}{|c|}{ Other immigrant states ${ }^{b}$} \\
\hline 1950 & 39.8 & 20.6 & 25.1 & 7.8 & 6.7 \\
\hline 1960 & 30.5 & 22.8 & 28.3 & 9.9 & 8.4 \\
\hline 1970 & 19.1 & 21.2 & 35.1 & 12.9 & 11.6 \\
\hline 1980 & 11.0 & 16.1 & 37.7 & 18.4 & 16.8 \\
\hline 1990 & 6.6 & 14.2 & 29.2 & 28.1 & 21.8 \\
\hline \multicolumn{6}{|l|}{ Other states } \\
\hline 1950 & 42.6 & 20.0 & 24.0 & 7.9 & 5.4 \\
\hline 1960 & 32.6 & 21.4 & 29.6 & 9.2 & 7.2 \\
\hline 1970 & 19.7 & 20.8 & 37.2 & 12.1 & 10.2 \\
\hline 1980 & 10.5 & 16.4 & 40.8 & 17.3 & 15.0 \\
\hline 1990 & 5.0 & 14.3 & 33.3 & 28.0 & 19.4 \\
\hline \multicolumn{6}{|l|}{ United States } \\
\hline 1950 & 40.7 & 20.2 & 24.9 & 8.2 & 5.9 \\
\hline 1960 & 31.0 & 21.8 & 29.5 & 9.9 & 7.7 \\
\hline 1970 & 18.8 & 20.6 & 36.6 & 13.1 & 10.9 \\
\hline 1980 & 10.5 & 16.0 & 39.2 & 18.4 & 15.9 \\
\hline 1990 & 6.0 & 14.2 & 30.8 & 28.6 & 20.4 \\
\hline
\end{tabular}

Source: Authors' calculations based on data from the census PUMS (various years).

a. Sample includes individuals aged eighteen to sixty-four and not living in group quarters.

b. New York. New Jersey. Illinois, Florida, and Texas.

\section{Does Immigration Change Factor Proportions within a State?}

The migration response of natives would completely diffuse the adverse effect of the immigrant supply shock on local labor markets if the native flows of particular skill groups counterbalanced the immigrant shock and left the relative factor proportions within a state unchanged. We now investigate whether this was, in fact, the case.

We begin by classifying workers according to the five educational groups defined above. Table 10 reports the trends in the factor shares of these skill groups in each of our three areas and in the United States 
as a whole. It therefore summarizes what happens to the relative supply of the skill groups in these regions as a result of both immigration and the internal migration flows of natives. There has been substantial convergence in the regional distribution of skills over 1950-90. At the beginning of the period, California had relatively few persons who lacked a high school diploma; in 1950, 47.3 percent of California's adult population had less than twelve years of schooling, as compared with 62.6 percent in the states without a strong immigrant presence. By 1990, 22.7 percent of California's population was in this educational group, as compared with 19.3 percent for the nonimmigrant states. California's share of less educated workers declined less rapidly than shares in the rest of the nation, both before and after the immigration shock. From being much more educated than the rest of the nation before 1970, the population of California has changed to a bimodal distribution, with a modestly larger share of both those with less than a high school degree and those with at least a college degree. Table 10 raises the question of whether the educational distribution of the populations of immigrant-receiving states moved closer to that of the rest of the country because of increased unskilled immigration or because of preexisting forces leading toward convergence in educational distributions across regions.

We formalize the analysis by estimating regression models designed to measure how the factor proportion of the various skill groups changed within a state over the period 1950-90. We define the change in factor proportions for skill group $k$ in state $j$ as

$$
\Delta p_{j k}\left(t, t^{\prime}\right)=\frac{L_{j k t^{\prime}}}{L_{j t^{\prime}}}-\frac{L_{j k t}}{L_{j t}},
$$

where $L_{j k t}$ gives the number of persons in state $j$ belonging to skill group $k$ at time $t$, and $L_{j t}$ gives the total number of persons living in the state. We define the immigrant contribution to the change in factor proportions over the period as

$$
\Delta \widetilde{m}_{j k}\left(t, t^{\prime}\right)=\frac{M_{j k t^{\prime}}}{L_{j t^{\prime}}}-\frac{M_{j k t}}{L_{j t}} .
$$

Consider the regression model

$$
\Delta p_{j k}(70,90)=c+d \Delta \widetilde{m}_{j k}(70,90)+v_{j}+\tau_{k}+e_{j k},
$$


where $v_{j}$ is a fixed effect indicating the state of residence and $\tau_{k}$ is a fixed effect indicating educational attainment. The empirical evidence presented in the previous section indicates that the growth rate of the total population in the state is essentially unrelated to immigration. This implies that one can treat the variable $\Delta \widetilde{m}_{j k}(70,90)$ as exogenous, despite the fact that the right-hand side includes a measure of $L_{j, 90}$. The state fixed effect helps to define the immigrant supply shock in terms of within-state deviations, so that the coefficient $d$ measures how factor proportions change within a state when a particular skill group experiences a supply shock. ${ }^{36}$ The coefficient $d$ has the interpretation

$$
d=\frac{L_{j, k, 90}-\gamma L_{j, k, 70}}{M_{j, k, 90}-\gamma M_{j, k, 70}}
$$

where $\gamma$ equals $L_{j, 90} / L_{j, 70}$, the state's population growth between 1970 and $1990 .{ }^{37}$ If the state's population had not changed over the period ( $\gamma$ equal to one), the coefficient $d$ would simply measure the change in the size of the population associated with the entry of an additional immigrant in that educational group $\left(\Delta L_{j k} / \Delta M_{j k}\right)$. If there were no migration response in the native population, the coefficient $d$ would then be one, while if native migration completely offset the immigrant supply shock, the coefficient would be zero. In fact, the state's population did increase over the period, for reasons independent of immigration. Consequently the coefficient $d$ measures the impact of an additional immigrant on the total population relative to what would be expected if all groups had experienced neutral growth (at the rate $\gamma$ ) over the period 1970-90.

Table 11 reports the estimated coefficient $d$ for a variety of regression specifications. The first row estimates the first difference model given by equation 11 . The coefficient reported in the first column of data

36. If there were only two skill groups in the population, $u$ and $s$, the fixed effect model of equation 11 would be numerically equivalent to the regression

$$
\begin{array}{r}
\Delta p_{j u}(70,90)-\Delta p_{j s}(70,90)=\left(\tau_{u}-\tau_{s}\right)+d\left[\Delta \widetilde{m}_{j u}(70,90)\right. \\
\left.\quad-\Delta \widetilde{m}_{j s}(70,90)\right]+\left(e_{j u}-e_{j s}\right),
\end{array}
$$

so that the regression would simply estimate how the difference in immigrant supply shocks between the two groups affects the factor proportions within the state.

37. In particular, note that $\Delta p_{j k}\left(t, t^{\prime}\right)=\left(L_{j k t^{\prime}}-\gamma L_{j k t}\right) / L_{j t^{\prime}}$ and that $\Delta \widetilde{m}_{j k}\left(t, t^{\prime}\right)=$ $\left(M_{j k t^{\prime}}-\gamma M_{j k t^{\prime}}\right) / L_{j r^{\prime}}$. 


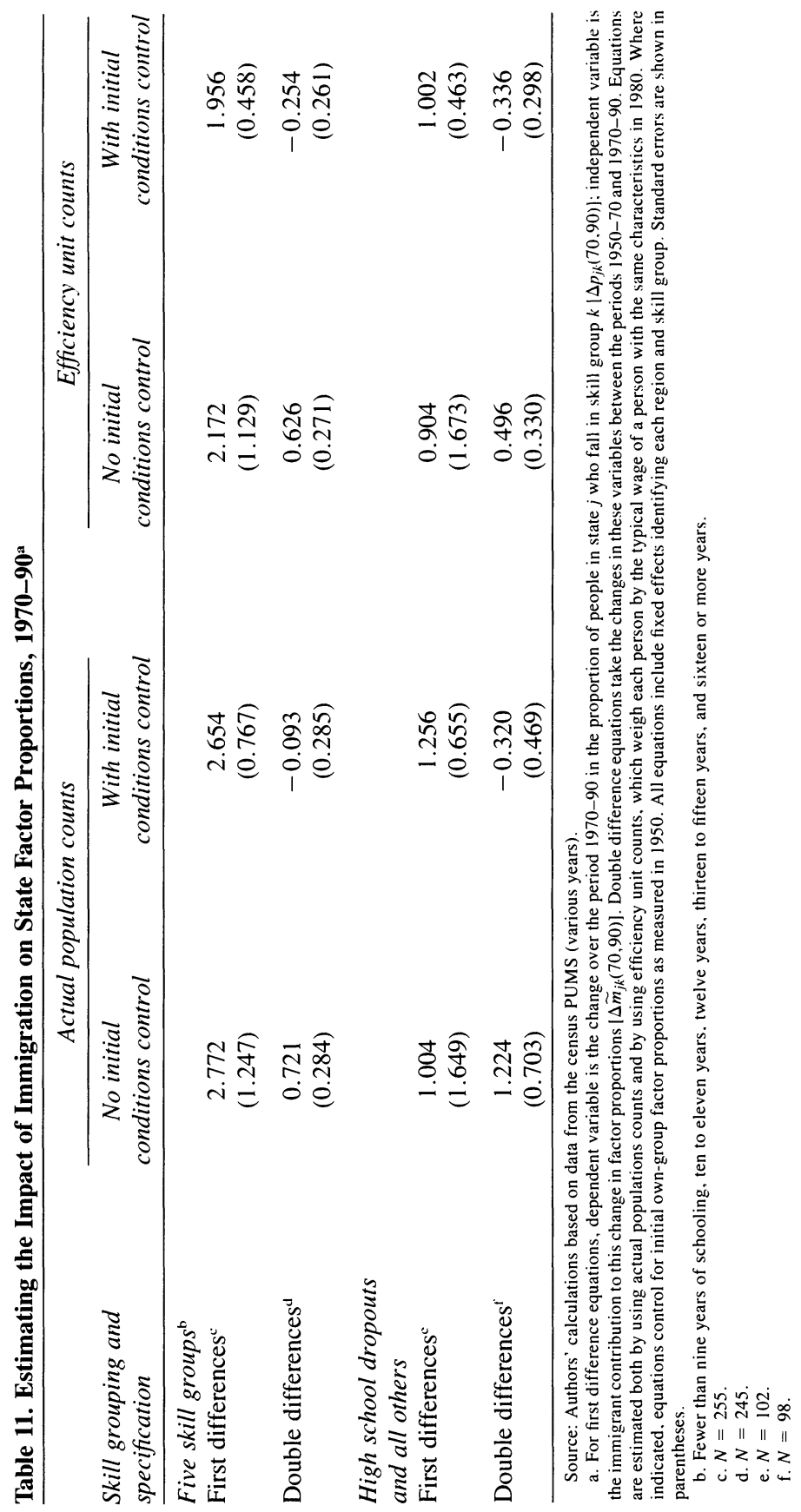


suggests that $d$ is strongly positive. An additional immigrant in a given skill group raises the total number of persons in that skill group by $2.8 .{ }^{38}$ But we have argued that a more useful counterfactual exercise is to compare the growth rate of a particular skill group before and after the immigrant supply shock. This suggests the alternative double difference regression specification

$$
\begin{aligned}
& \Delta p_{j k}(70,90)-\Delta p_{j k}(50,70) \\
& \quad=\alpha+\delta\left[\Delta \widetilde{m}_{j k}(70,90)-\Delta \widetilde{m}_{j k}(50,70)\right]+v_{j}+\tau_{k}+e_{j k} .
\end{aligned}
$$

The second row of table 11 shows that the estimated $\delta$ is 0.72 . This implies, at most, a moderate native response to immigration within a skill group, indicating that immigration does alter factor proportions within a state.

Our discussion of the raw data describing trends in the differences of skill distributions between geographic regions, as shown in table 10 , suggests that the regression models of equations 11 and 13 ignore a factor that played a key role over the period 1950-90: the convergence of skill distributions across states. This process was in operation before the immigrant supply shock began. To control for the convergence, we add to the regression model a variable giving the fraction of the state's adult population that belonged to educational group $k$ in 1950: $L_{j, k .50} /$ $L_{j .50}$. The resulting coefficients from the expanded specification are reported in the second column of table $11 .{ }^{39}$ The inclusion of this "initial conditions" variable does not affect the estimated migration effect in the single difference model, but does reduce the impact of immigration on the total supply of workers in a given skill group to zero in the double difference model. In other words, when one controls for the state's preexisting conditions (both in terms of the initial skill distribution and the rate at which this distribution was changing before 1970), the evidence suggests that immigration does not alter the factor proportions of skill groups within a state.

38. Card (1997) also reports a positive correlation between the number of immigrants in a particular skill group who entered a local labor market and the number of similarly skilled natives who chose to reside in that labor market in the period 1985-90.

39. The coefficient of the 1950 factor proportion has a strong negative effect in all the models estimated in this section, suggesting the importance of convergence in educational levels across states. 
The last two rows of table 11 report the regression results when we redefine skill groups by aggregating to the two groups whose factor proportions are most sensitive to immigration: workers with less than a high school education and workers with at least a high school education. The single difference models consistently yield a strong positive correlation between immigration and changes in factor proportions within these aggregated skill groups, but this positive effect vanishes when we control for the pre-1970 growth rates of the skill groups in the state and for the convergence process.

Finally, we convert the population counts into efficiency units by weighting each person by the relative wage of a person who has similar observed characteristics (that is, sex, age, education, and nationality) in the base period $1980 .{ }^{40}$ Calculating supply shifts in terms of efficiency units yields a better measure of changes in the supplies of particular skill groups than the simple population counts used throughout our analysis. We use these efficiency unit counts to reestimate the various specifications; the last two columns of table 11 show that our regression results are not affected.

In sum, the answer to whether immigration affects factor proportions within a state appears to depend on how one specifies the counterfactual of what would have happened absent immigration. Under our preferred specification-which controls for the initial level and past change in state skill distributions-the evidence shows that much of the adverse impact of immigration on the economic opportunities of workers in areas directly affected by the immigrant supply shock was diffused across the country, as native migration flows responded to local influxes of immigrants. ${ }^{41}$

40. We divide the labor force aged eighteen to sixty-four into 280 distinct groups based on sex-age-education-nationality cells $(2$ sex groups $\times 5$ age groups $\times 4$ education groups $\times 7$ nationality groups $=280$ cells). The age groups are eighteen to twenty-four, twenty-five to thirty-four, thirty-five to forty-four, forty-five to fifty-four, and fifty-five to sixty-four; the educational groups are fewer than twelve years of schooling, twelve years, thirteen to fifteen years, and sixteen plus years; and the nationality groups are black U.S. natives, nonblack U.S. natives, Mexican immigrants, other Latin American immigrants, European immigrants, Asian immigrants, and other immigrants. We then calculate the average hourly wage for full-time workers in each cell using the 1980 census PUMS and weight individuals by the estimated average wage for their sexage-education-nationality cell in 1980 .

41. An alternative way to examine the effects of immigration would be to look at 


\section{The Aggregate Factor Proportions Approach}

Trade theorists have long recognized that trade and immigration (and international capital flows) are potentially substitute ways for a country to make use of factors that are scarce within its borders..$^{42}$ Nevertheless, empirical studies of trade and immigration have proceeded independently. To the extent that trade and immigration are substitute means of altering effective national factor proportions, it is incorrect to analyze them separately. Examining how changes in trade affect U.S. workers without recognizing that in the absence of trade there will be increased economic incentives for greater immigration (or capital flows) will likely overstate the effects of trade. Examining how immigration affects U.S. workers without recognizing that reduced levels of immigration will create incentives for greater trade (and capital flows) will likely overstate the economic effects of immigration.

In earlier work, we tried to remedy this problem by analyzing how trade and immigration together alter the nation's endowments of labor skills. ${ }^{43}$ The basic idea of our aggregate factor proportions approach is to compare the nation's actual supplies of skilled and unskilled labor to those it would have had at different levels of immigration or trade; and then to assess the relative wage consequences of these immigrationor trade-induced changes in factor supplies, where the effective factor endowment of a given skill group is the sum of the number of native workers, the number of immigrants, and the number of workers "em-

wages or employment on an occupational basis. Complaints by groups of mathematicians and software engineers about immigrant competition and the American Medical Association's proposal to restrict foreign supply of medical personnel show that native workers in these areas perceive considerable competition from foreign-born workers. There is, however, a major problem in using occupations as a unit of observation over the period covered by the immigration shock: the Census Bureau implemented a major reclassification of occupations between the 1970 and 1980 censuses (U.S. Bureau of the Census, 1989). Our own exploratory work relating occupational earnings to immigrant intensities suggests that empirical results are sensitive to the concordance among the occupations over the period. In our view, an occupations-based approach merits further study as an alternative to the spatial correlations approach, bearing in mind this basic problem. For an insightful study using occupations as the unit of analysis, see Friedberg (1996), who uses data on the occupational distribution of recent Russian immigrants to Israel before and after immigration to examine effects of immigration on Israeli natives.

42. See Mundell (1957) for this view of trade and immigration.

43. Borjas, Freeman, and Katz (1992, 1996). 
bodied" in net imports. We estimate the latter using fixed coefficient factor content calculations.

In its simplest form, our analysis uses a constant elasticity of substitution (CES) aggregate production function with two inputs: skilled labor $(s)$ and unskilled labor $(u)$. We postulate that relative wages are determined by the intersection of an inelastic (predetermined) short-run relative labor supply function and a downward-sloping relative labor demand function derived from the CES. In this framework, skilled wages relative to unskilled wages in year $t, w_{s t} / w_{u t}$, will depend on the relative labor supplies in year $t, x_{s t} / x_{u t}$, and the level of relative labor demand, so that

$$
\ln \frac{w_{s t}}{w_{u t}}=\frac{1}{\sigma}\left(D_{t}-\ln \frac{x_{s t}}{x_{u t}}\right),
$$

where $\sigma$ is the aggregate elasticity of substitution between skilled and unskilled workers and $D_{t}$ indexes log relative demand shifts for skilled workers. ${ }^{44}$ The impact of a given change in relative skill supplies depends inversely on the magnitude of $\sigma$.

As noted, the national (implicit) supply of skill group $k$ at time $t$ has three components: native workers $\left(N_{k t}\right)$, immigrant workers $\left(M_{k t}\right)$, and the effective supply of workers of type $k$ contained in net trade flows $\left(T_{k t}\right)$ :

$$
x_{k t}=N_{k t}+M_{k t}+T_{k t}=N_{k t}\left(1+\frac{M_{k t}+T_{k t}}{N_{k t}}\right) .
$$

The log relative supply of skilled workers is affected by the skill composition of the native work force and the relative contributions of immigration and trade to the supplies of skilled and unskilled workers:

$$
\ln \frac{x_{s t}}{x_{u t}}=\ln \frac{N_{s t}}{N_{u t}}+\ln \left(1+\frac{M_{s t}+T_{s t}}{N_{s t}}\right)-\ln \left(1+\frac{M_{u t}+T_{u t}}{N_{u t}}\right) .
$$

44. The aggregate elasticity of substitution $(\sigma)$ reflects not only technical substitution possibilities in production at the firm or industry level, but also consumer substitution possibilities across goods and services. The appropriate value of $\sigma$ for assessing how aggregate changes in relative skill supplies affect relative wages is likely to be substantially larger than the elasticity of substitution in production of skilled and unskilled workers for a representative firm or industry. 
We assume that the stock of immigrants at time $t$ is predetermined relative to trade flows. Thus the separate contributions of immigration and trade to the $\log$ relative supply of skilled workers, $\ln \left(x_{s t} / x_{u t}\right)$, are given by

$$
\text { immigration contribution }=\ln \left(1+\frac{M_{s t}}{N_{s t}}\right)-\ln \left(1+\frac{M_{u t}}{N_{u t}}\right)
$$

and

$$
\text { trade contribution }=\ln \left(1+\frac{T_{s t}}{L_{s t}}\right)-\ln \left(1+\frac{T_{u t}}{L_{u t}}\right),
$$

where $L_{k t}=N_{k t}+M_{k t}$ is the direct labor supply of group $k$ (both nativeand foreign-born).

To use equations 14,17 , and 18 to assess how immigration and trade affect the wages of more skilled natives relative to those of less skilled natives, we need the following information: the change in the number of immigrants relative to natives with different levels of skill; the implicit change in skill supplies embodied in trade; and an estimate of the responsiveness of relative wages to relative skill supplies $(1 / \sigma)$. We also need to aggregate heterogeneous workers into our aggregates of skilled and of unskilled labor. Since the aggregate factor proportions approach simulates what might have happened to the labor market under different immigration and trade scenarios, we must also carefully specify the counterfactual under consideration.

\section{When Are Factor Contents Useful?}

Under what conditions will this framework provide useful insight into the effects of immigration and trade on the labor market? The first condition is that changes in national relative skill supplies affect national relative wages. If the world economy were sufficiently integrated to create factor price equalization among countries, then relative labor supply conditions in the world would enter the wage determination equation. ${ }^{45}$ Neither national demand nor national supply conditions

45. For this argument in relation to the world economy, see Leamer (1996a); and in relation to the Organisation for Economic Co-operation and Development, see Davis (1996) and Krugman (1995a). 
would affect relative wages, except to the extent they changed relative demand and supply within the world economy. But a large body of empirical evidence shows that national economic conditions $d o$ affect relative wages by skill and education. Many time-series studies of the United States find that increases in the (detrended) relative supply of more educated workers are negatively related to changes in the relative wages of more educated workers. ${ }^{46}$ Similar correlations have been found for many other countries, including Britain, Canada, South Korea, and Sweden. ${ }^{47}$ Canada and the United States have sufficiently separate labor markets that differences in the rates of growth of the relative supply of college-educated workers from the 1970 s to the $1980 \mathrm{~s}$ help to explain the much larger growth in the college-high school wage differential in the United States during the $1980 \mathrm{~s} .{ }^{48}$ More generally, research indicates that levels and changes in relative pay by skill across countries depend substantially on national wage-setting institutions and relative skill supplies. ${ }^{49}$

The second condition is that one can define skill categories to distinguish which groups of immigrants and natives are substitutes or complements. The standard assumption is that persons with the same number of years of schooling are perfect substitutes and those with different levels of schooling are imperfect substitutes (possibly, complements). But immigrants earn less than natives with the same schooling, so perhaps they should be viewed as substitutes for natives with modestly lower education. A sizable number of immigrants have less than nine years of schooling, which could make them complements even for native high school dropouts with nine to eleven years of schooling. And some immigrants work in specialized areas where they may complement natives with similar skills-for example, as language teachers or owners of specialty restaurants.

Determining which groups of immigrants compete with which groups of natives is not a trivial issue. If one uses years of schooling to define skill categories, one obtains different pictures of immigrant effects on factor proportions depending on where one cuts the schooling distri-

46. Freeman (1975); Katz and Murphy (1992); Murphy and Welch (1992).

47. On these countries respectively, see Schmitt (1995), Freeman and Needels (1993), Kim and Topel (1995), and Edin and Holmlund (1995).

48. Freeman and Needels (1993).

49. See, for example, Blau and Kahn (1996) and Freeman and Katz (1994). 
bution. We deal with this problem by specifying competing native groups based both on alternative educational groupings and on the position of immigrants in the native earnings distribution.

The third condition is that the estimate of the effect of trade on national skill proportions captures the full impact of trade on wages. This is a contentious and difficult issue, on which trade economists have divergent views. Some believe that factor content analyses are essentially meaningless; others regard them as a valid measure of potential trade effects on the labor market for modest trade shocks relative to a well-defined baseline scenario. Some argue that all the information needed to assess the effects of trade on the labor market is contained in the prices of traded goods, which have magnified effects on wages, and that actual trade flows are irrelevant. Little did we realize when we wrote our 1992 paper using factor content analysis that the field would become such a battle zone. ${ }^{50}$

There are circumstances under which factor content analyses are justifiable in standard trade models. If one begins with autarky and then allows for trade, and trade is a modest proportion of the national economy, the change in national factor endowments due to the factor content of trade measures the pressure of trade for changes in relative wages. ${ }^{51}$ In this scenario, as in our model, the fall of trade barriers creates a flow of tradables whose factor content times the reciprocal of the appropriate elasticity of substitution produces the implied effect of the opening of trade on relative wages.

But there are also circumstances under which the flows of traded goods may bear little or no relation to the pressure from trade on wages. As an extreme case, suppose that an LDC firm begins producing souvenirs of the Empire State building and informs souvenir stands that it can provide products at lower prices than U.S. producers. The souvenir stands will then inform American manufacturers that they have to meet the new price to keep their business. The U.S. firms, in turn, will tell their workers that the firms can stay in business only if the workers take a pay cut. If the workers accept the cut, the U.S. firms will maintain

50. On the problems with factor content analyses, see Leamer (1996b) and Deardorff and Hakura (1994); on their validity, see Deardorff and Staiger (1988), Krugman (1995b), Sachs and Shatz (1994), and Wood (1994, 1995); and on the irrelevance of actual trade flows, see Bhagwati and Dehejia (1994).

51. Deardorff and Staiger (1988); Krugman (1995b). 
their hold on the souvenir market, with no new trade flows. But the threat of trade (like the threat of entry in a contestable market) will have reduced wages in the United States. In this example, the only "footprint" of trade is the change in the relative price of souvenirs. This is, in stark form, the argument that trade flows do not accurately reflect trade pressures on the labor market.

This model is difficult to assess empirically, and there have been only limited efforts to do so. ${ }^{52}$ The analyst must show, first, that the domestic relative price of goods produced by the less skilled has fallen; and second, that this price change is due to the "unobservable" threat of trade rather than some other factor (for example, differences in sectoral rates of technological change or, as in the 1980s, a fall in the real value of the minimum wage). If foreign goods are imperfect substitutes for U.S.-made goods in the same sector, the analyst must assess the degree of substitutability. In a world in which product and labor demand curves in traded goods are not perfectly elastic at the "going world price", and in which native workers in the traded goods sector may earn some economic rents, trade may also alter the wage structure by making demand curves more elastic and squeezing those rents. ${ }^{53}$ Moreover, the model implies that labor skill ratios fall within sectors, as firms substitute toward the low-skill workers displaced from importcompeting industries-which is contrary to the observed rise in those ratios. ${ }^{54}$ While the price-side model may be hard to estimate, it does suggest that factor content analyses that infer the effect of trade on implicit national factor endowments from observed trade flows are likely to understate the impact of trade on relative wages. ${ }^{55}$

There is yet another area of controversy in factor content analysis. The standard analysis estimates the labor supply embodied in traded goods using current average unit labor coefficients for different skill categories from import-competing and export-producing sectors in the

52. See, for example, Sachs and Shatz (1994), Krueger (1997), and Baldwin and Cain (1997).

53. On the elasticity of demand curves, see Rodrik (1997); on the squeezing of rents, see Borjas and Ramey (1995).

54. See Lawrence and Slaughter (1993), Berman, Bound, and Griliches (1994), and Autor, Katz, and Krueger (1997).

55. Baldwin and Cain (1997) provide a useful examination of the evidence on price effects and find similar modest impacts of trade on U.S. relative wages using both the price and factor content approaches. 
home economy. ${ }^{56}$ But Adrian Wood argues that one should not use unit labor coefficients from current advanced country production relations when assessing the factor content of imports from LDCs to advanced industrial nations. ${ }^{57}$ One reason is that within every sector there is a wide distribution of labor input coefficients, reflecting differences in skill intensities of employment, differences in labor productivity, and differentiated products. If LDC trade has driven out the most unskilled labor-intensive modes of production from an import-competing industry, current average labor input coefficients will understate the effect of LDC trade in augmenting the effective supply of less skilled workers in advanced nations. The appropriate labor input coefficients are those for the marginal technologies and products that would expand in importcompeting sectors absent this trade. Wood also argues that firms may alter their technologies or input coefficients in response to trade pressures.

We are sympathetic to Wood's argument. As he emphasizes, there is substantial heterogeneity in the relative utilization of less skilled workers (that is, high school dropouts) across plants. Tabulations from the Worker-Establishment Characteristic Database (WECD), an employer-employee matched database for U.S. manufacturing in 1990 compiled by the U.S. Bureau of the Census, show substantial differences in the educational composition of the work force within detailed manufacturing industries. ${ }^{58}$ Within the typical three-digit industry, the employment share of high school dropouts in the bottom quarter of plants, ranked by average worker education, is 2.4 times the industry average (0.40 versus 0.17) ${ }^{59}$ Mark Doms, Timothy Dunne, and Kenneth Troske find that establishments with less educated workers are much less likely to use new technologies than those with more skilled workers in the same industry. J. Bradford Jensen and Troske find that in most four-digit manufacturing industries in 1992, the ninetieth percentile plant (ranked by labor productivity) had labor productivity that was over three times that of the tenth percentile plant.$^{60}$ If LDC imports

56. See, for example, Sachs and Shatz (1994).

57. Wood (1994, 1995).

58. We are grateful to Kenneth Troske for these tabulations. The WECD is documented and described in Troske (1995) and Doms, Dunne, and Troske (1997).

59. The bottom quarter of plants, in terms of average worker education, employ 15 percent of all workers in the typical industry.

60. Doms, Dunne, and Troske (1997); Jensen and Troske (1997). 
affect the less skilled and lower productivity segment of a three-digit industry, then the actual increment to the implicit supply of low-skilled workers from such trade flows could easily be three times larger than the estimates based on current average industry skill shares and labor productivity levels.

To address this issue, Wood takes input coefficients from LDCs and adjusts them for relative wages in the United States or western Europe to approximate marginal input coefficients and assumes that, absent trade, technologies would not improve in the traded goods sector. Elsewhere, we use input coefficients averaged over an earlier period (1967-87), but do not examine the sensitivity of results to alternative assumptions ${ }^{61}{ }^{1}$ In the present study, we use U.S. input coefficients (skill shares) from past years $(1970,1980,1990)$ and carefully specify our assumptions about the technology for producing import-competing and other goods and product demand responses.

\section{The Facts to Be Explained}

It is well documented that educational wage differentials and overall wage inequality have greatly increased in the United States since the late 1970s. Most estimates of changes in educational wage differentials are based on samples containing both U.S. natives and immigrants. ${ }^{62}$ Since recent immigrants typically earn less than U.S. natives with the same level of education, the disproportionately growing share of immigrants among less educated workers in the United States means that the usual estimates may overstate changes in relative wages by education for U.S. natives. To assess the contributions of immigration- and trade-induced changes in relative labor supplies on the relative wages of U.S. natives requires estimates of changes in educational wage differentials for U.S. natives alone.

Table 12 presents estimates for three measures of educational wage differentials for natives between 1960 and 1995. The differentials are derived from cross-section regressions of log hourly earnings on five education dummies (zero to eight years of schooling, nine to eleven years, thirteen to fifteen years, sixteen years, and seventeen plus years,

61. Borjas, Freeman, and Katz (1992).

62. See, for example, Bound and Johnson (1992) and Mishel, Bernstein, and Schmitt (1997). 
Table 12. Native Log Wage Differentials, by Educational Attainment, 1960-95a

Log point difference

\begin{tabular}{|c|c|c|c|}
\hline Year & $\begin{array}{c}\text { College graduate } \\
\text { relative to } \\
\text { high school graduate }\end{array}$ & $\begin{array}{c}\text { College or more } \\
\text { relative to } \\
\text { high school graduate }\end{array}$ & $\begin{array}{l}\text { High school or more } \\
\text { relative to } \\
\text { high school dropout }\end{array}$ \\
\hline 1960 & 0.319 & 0.317 & 0.280 \\
\hline 1970 & 0.362 & 0.374 & 0.312 \\
\hline 1980 & 0.279 & 0.304 & 0.301 \\
\hline 1990 & 0.412 & 0.458 & 0.374 \\
\hline 1995 & 0.420 & 0.495 & 0.410 \\
\hline
\end{tabular}

Source: Authors' calculations. Wage data for 1960-90 actually refer to 1959, 1969, 1979, and 1989 and are from the census PUMS. Wages for 1995 are extrapolated from the 1990 census PUMS, using observed changes between the February 1990 CPS and the 1995 CPS. MORG file.

a. Wages are hourly earnings of full-time native wage and salary workers aged eighteen to sixty-four, adjusted for age. sex. race, and region, as described in the text.

b. Log wage of natives with exactly sixteen years of schooling less that of natives with exactly twelve years.

c. Log wage of natives with sixteen or more years of schooling less that of natives with exactly twelve years.

d. Log wage of natives with twelve or more years of schooling less that of natives with fewer than twelve years.

with twelve years as the base group), a quartic in age, a female dummy, a nonwhite dummy, and three region dummies. Our samples comprise native full-time workers aged eighteen to sixty-four, from the 1960, 1970, 1980, and 1990 census PUMSs and the Merged Outgoing Rotation Group (MORG) file of the 1995 Current Population Survey (CPS) from the Bureau of Labor Statistics. The first column of table 12 displays the log wage gap between workers with exactly sixteen years of schooling (college graduates) and those with exactly twelve years of schooling (high school graduates). The second column expands the college group to include those with advanced degrees. Both measures of the college-high school wage differential expand modestly in the 1960 s, contract in the 1970s, and increase substantially in the 1980s. The growth rate in the college-high school wage gap slows down from 1990 to 1995 , but the increase over this period remains sizable when those with advanced degrees are included in the college group. The time pattern of changes in the college-high school wage gap for natives is quite similar to estimates for the overall U.S. work force, using samples that include both immigrants and natives. ${ }^{63}$

The last column of table 12 examines the wage of native high school dropouts relative to that of natives with at least twelve years of schooling. High school dropouts are the group most likely to be adversely

63. See, for example, Autor, Katz, and Krueger (1997). 
affected by the recent growth of less skilled immigration and trade with LDCs. The relative earnings of native high school dropouts declined by $0.073 \log$ point from 1980 to 1990 and continued to decline at the same rate in the early 1990 s.

Note that there has been a decline in the relative wages of less educated workers since 1980, even though the relative supply (of both natives and immigrants) has continued to decline. Table 13 documents changes in the educational composition of direct U.S. labor input (natives plus immigrants), measured in full-time equivalents (or total hours worked), from 1960 to $1995 .{ }^{64}$ Although the share of high school dropouts has declined consistently and the share of college equivalents has grown throughout the past thirty-five years, the rate of growth of the relative supply of more educated workers accelerated in the 1970s and decelerated in the 1980s. The slower growth of the relative supply of skills may help to explain the quite different outcomes for relative wages by education in the 1970s and in the 1980s and 1990s illustrated in table 12 .

To examine the impact of the supply shifts induced by trade and immigration on native relative wages, we aggregate workers into skill groups in two ways. First, following David Autor, Katz, and Alan Krueger and also George Johnson, we aggregate the labor force into high school equivalents (all workers with twelve or fewer years of schooling and one-half of those with some college education) and college equivalents (all workers with at least a college degree and one-half of those with some college education). ${ }^{65} \mathrm{Katz}$ and Kevin Murphy show

64. Changes introduced in the 1990 census to the educational attainment question make it difficult to assess accurately changes in relative education supplies over the 1980s using the public use samples of the 1980 and 1990 censuses. The CPS continued to use the old question ("highest grade attended and completed") through 1991. Thus the 1980 and 1990 CPS, MORG files have consistent education coding and can be used to measure changes in relative supplies by educational group. The February 1990 CPS asked individuals about educational attainment with both the new and the old questions. We estimate changes from 1990 to 1995 using the February 1990 CPS and the 1995 CPS, MORG file. Changes from 1990 to 1995 should be interpreted with some caution, because the complete overhaul of the CPS in 1994, with the shift to computer-assisted interviewing, implies the possibility of unknown differences in responses to education questions. We use the coding scheme suggested by Jaeger (1997) for the new census and CPS education codes, classifying workers indicating twelve years of schooling but no degree as high school graduates. The data appendix of Autor, Katz, and Krueger (1997) provides additional information on these issues of data comparability.

65. Autor, Katz, and Krueger (1997); Johnson (1997a). 


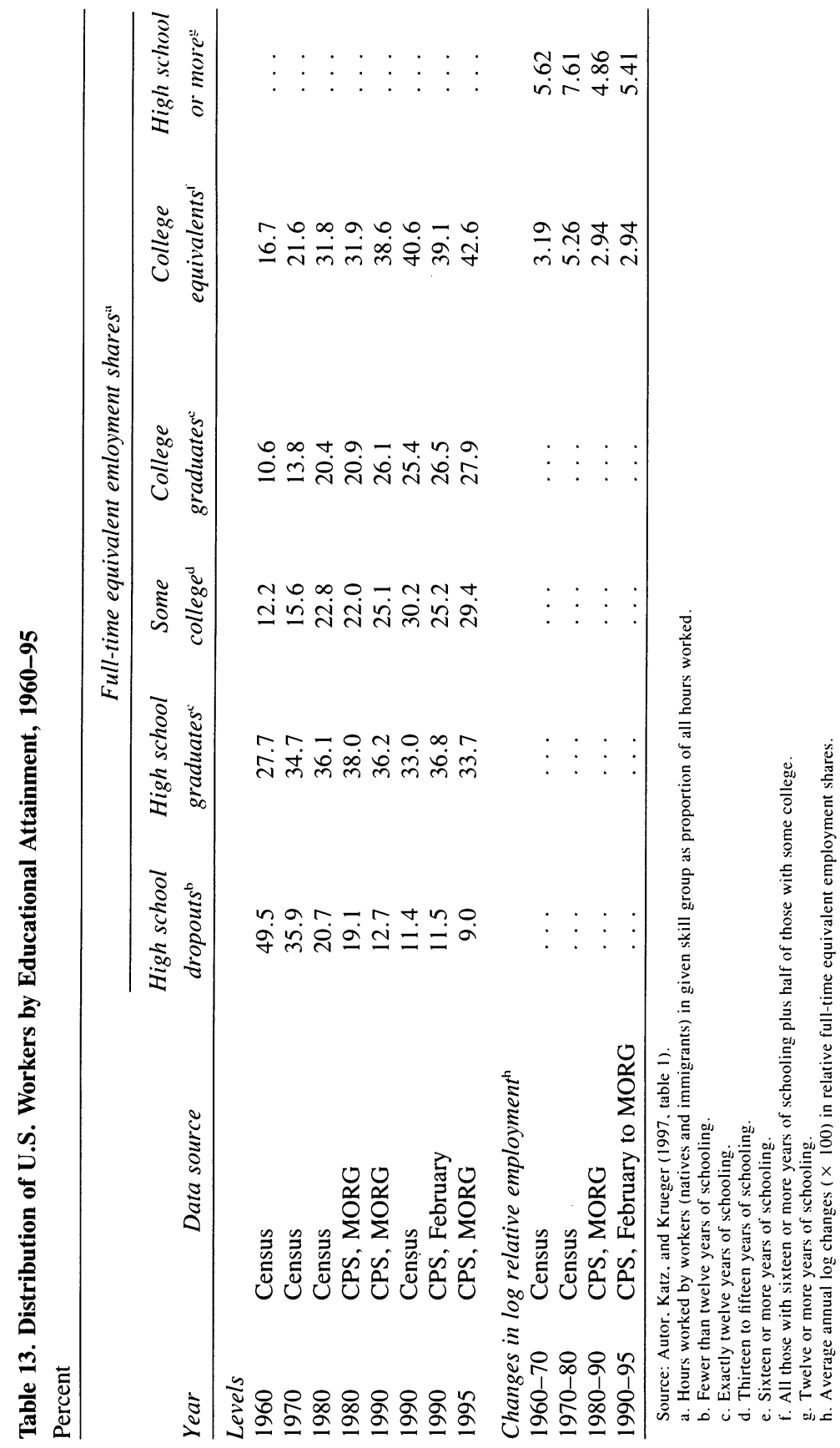


that detrended changes in the supplies of similar aggregates of college equivalents relative to high school equivalents do a reasonable job of explaining changes in a broad measure of the college-high school wage differentials such as that presented in the second column of table $12 .{ }^{66}$ They estimate a version of equation 14 and find the elasticity of the relative wage of college graduates to changes in the relative supply of college equivalents is approximately -0.709 (implying an economywide estimate of the elasticity of substitution between college equivalents and high school equivalents, $\sigma$, of 1.41). Thus we calculate immigration- and trade-induced changes in the relative supplies of college and high school equivalents and examine the implied relative wage effects using the Katz-Murphy estimate of the wage elasticity.

Second, we divide the labor force into high school dropouts and all other workers and use an estimated wage elasticity for the response of the relative wage of dropouts to their relative supply of -0.322 , from time-series estimates covering the period 1963-87 that we report in an earlier study. ${ }^{67}$

We address compositional changes within our broad educational groups by adjusting the changes in hours by skill group into efficiency units, by weighting each individual's hours by the average wage of an individual with similar observed characteristics (that is, sex, age, education, and nationality) in a base period (1980). ${ }^{68}$

\section{The Effect of Immigration on Relative Labor Supplies}

Table 14 shows our estimates of the contribution of immigration to labor supply in efficiency units by broad educational groups from 1960 to 1995 . The first two columns display the immigrant-to-native effi-

66. Katz and Murphy (1992).

67. Borjas, Freeman, and Katz (1992).

68. Katz and Murphy (1992) provide a justification for this efficiency units approach to aggregation in measuring how relative supply and demand shifts affect relative wages by skill group. In the present study, we divide the labor force aged eighteen to sixtyfour into 280 distinct groups based on sex-age-education-nationality cells ( 2 sex groups $\times 5$ age groups $\times 4$ education groups $\times 7$ nationality groups $=280$ cells). We calculate the average hourly wage for full-time workers in each cell using the 1 percent random sample from the 1980 census PUMS for natives and 5 percent random sample from the 1980 census PUMS for immigrants. Thus we weight each individual's annual hours of work by the estimated average wage for their sex-age-education-nationality cell in 1980 . See note 40 for more details on the definition of the groups. 


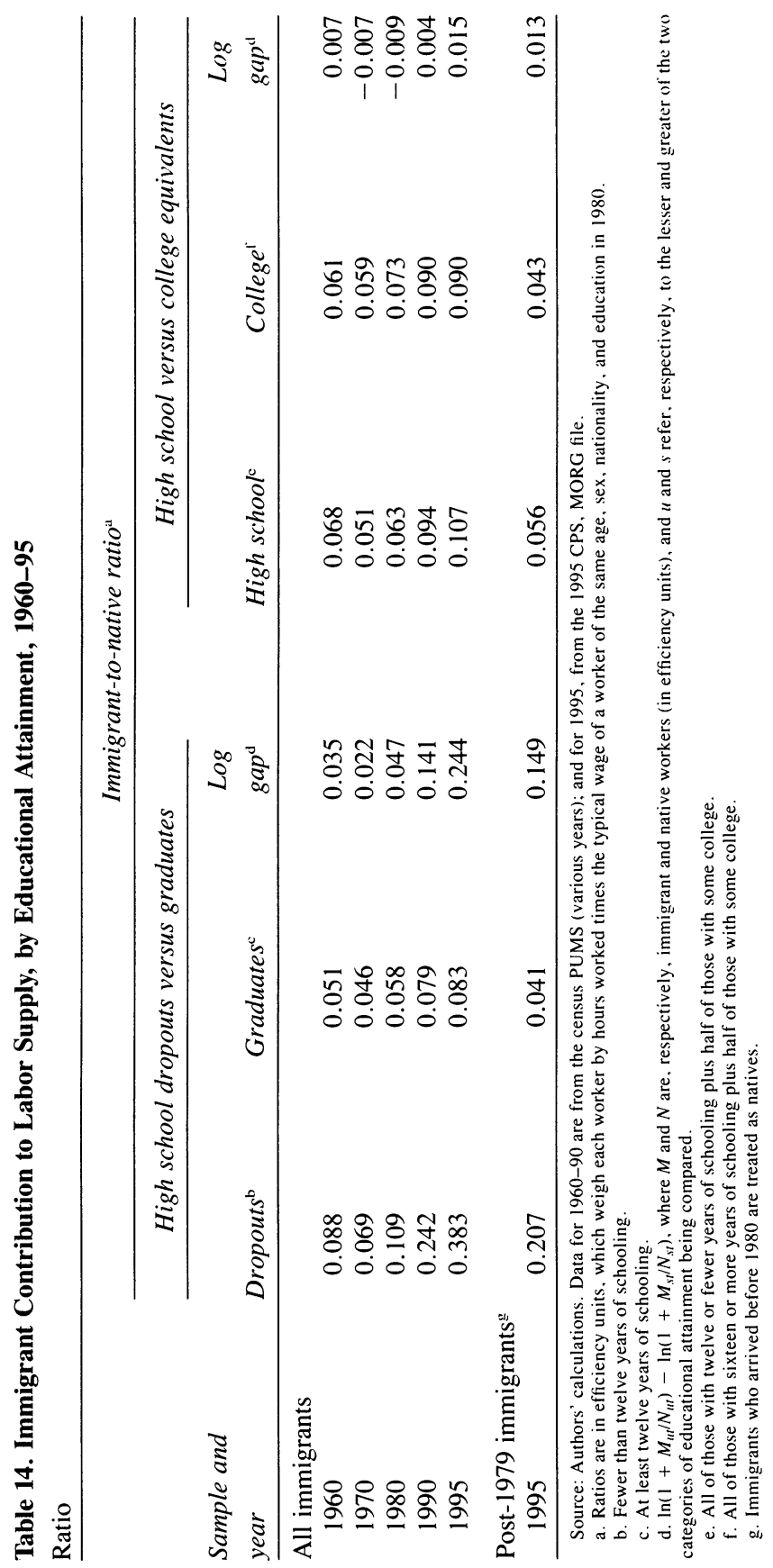


ciency unit ratios $(M / N)$ for high school dropouts and those with at least twelve years of schooling. The third column follows equation 17 in presenting the immigration contribution to the log supply of dropouts relative to more educated workers. The estimates for all immigrants in table 14 show the growing contribution of immigration to the supply of high school dropouts, especially since 1980; the ratio of immigrants to natives among dropouts increased from 0.109 in 1980 to 0.383 in 1995. ${ }^{69}$ These changes reflect both the rapid decline of the share of native labor force participants who are dropouts and the increased immigration since 1980, while there was little decline in the share of immigrant workers who have less than twelve years of schooling.

Some of the growth shown in table 14 in the immigrant contribution to the relative supply of dropouts since 1980 would have occurred even if immigration had been cut off in 1980. This is because of differences in the age structure of less educated immigrants and natives in 1980. To determine the effect on the labor supply by education of those immigrants who entered after 1979, in the last row of table 14 we treat all immigrants living in the United States before 1980 as natives. Post1979 immigrants increased the relative supply of dropouts in 1995 by $0.149 \log$ point, which is $0.048 \mathrm{log}$ point smaller than the $0.197 \mathrm{log}$ point increase from 1980 to 1995 shown in the upper panel of the table.

With our preferred relative wage elasticity for dropouts of -0.322 , the estimates in the first three columns of table 14 imply that the immigrant contribution to the relative supply of dropouts can explain a change in the wage of dropouts relative to that of nondropouts of be-

69. The Census Bureau switched its approach to adjusting sampling weights by age, sex, race or Hispanic origin, and state starting with the implementation of the revised CPS survey in 1994. Barry Edmonston has pointed out to us, in personal communication, that demographers have raised concerns that the official sampling weights may underweight the Asian and American Indian populations by 30 percent or more in the 1995 CPS. Since Asians are disproportionately immigrants, and more educated than the typical immigrant, our tabulations of immigrant employment and efficiency unit shares from the 1995 CPS, MORG file may slightly overestimate the relative contribution of immigrants to less educated skill groups in comparison with more educated skill groups. We checked the sensitivity of all our findings from the 1995 CPS increasing the relative weights of Asians and American Indians in the sample by 30 percent. The effects of this adjustment are modest in every case and lead to no substantive changes in our conclusions. For example, the log relative supply contribution of immigrants to dropouts declines from 0.244 to 0.243 and the log relative supply contribution of immigrants to high school equivalents declines from 0.015 to 0.012 , when the 1995 CPS sample is reweighted in this manner. 
tween -0.048 and $-0.063 \log$ point from 1980 to 1995 . Thus the factor proportions approach, treating immigrant and native efficiency units within the dropout and graduate skill categories as perfect substitutes, implies that immigration-induced changes in labor supply may account for 44 to 58 percent of the $0.109 \log$ point decline in the relative earnings of dropouts over this period.

The last three columns of table 14 reveal only modest effects of immigration on the supply of high school equivalents relative to college equivalents. Since the education distribution of immigrants is bimodal-many have less than twelve years of schooling and many have college and advanced degrees - the effect of immigration on relative skill supplies is greatly diminished when one aggregates workers into high school and college equivalent workers. The estimate for all inmigrants puts the immigration impact on the relative supply of high school equivalents at $0.024 \log$ point from 1980 to 1995 . The estimate for post-1979 immigrants indicates that these expanded the relative supply of high school equivalents by $0.013 \mathrm{log}$ point in 1995 . Using our preferred relative wage elasticity of -0.709 , we estimate that the contribution of immigration to changes in the college-high school wage differential from 1980 to 1995 ranges from 0.009 to 0.017 log point; or 5 to 9 percent of the actual $0.191 \log$ point increase in the collegehigh school wage differential for U.S. natives over this period.

We conclude that the immigrant-induced increases in relative labor supply are strongly concentrated on U.S. workers with fewer than twelve years of schooling and that the slowdown in the rate of decline of the relative supply of dropouts due to unskilled immigration may explain a sizable fraction of the decline in the earnings of dropouts relative to those with twelve or more years of schooling over the period 1980-95. In contrast, the immigrant supply contribution for a broader group of less educated workers is too small to account for even 10 percent of the sharp growth in the college-high school wage differential during this period.

In our assessment of the immigrant contribution to changes in skill supplies, we classify workers into skill groups by years of schooling. Under this approach, the impact of less skilled immigration on the relative supply of less educated natives is magnified by the rapidly declining share of high school dropouts in the native labor force. But low-wage and less skilled immigrants may compete with a broader 
group of low-wage natives than native high school dropouts. As an alternative way to measure immigrant-induced changes in labor market competition, we classify workers into skill groups based on their hourly wages rather than level of education. We sort workers by wages in each year (1980, 1990, and 1995) and define skill groups by percentile cutoff points in the native wage distribution. ${ }^{70} \mathrm{We}$ focus on two aggregation schemes: (a) workers with wages above and below the twentieth percentile of the native wage distribution (since the share of dropouts in the labor force in 1980, when the large immigration shock began, was approximately 20 percent); and (b) workers with wages above and below the sixtieth percentile of the native wage distribution (a group close in size to high school equivalents in 1980). Immigrant contributions to the relative supply of these two groups are determined by the difference in the ratio of immigrants to natives above and below the cut-off point in the native wage distribution defining the low- and highskill aggregates. Thus we compare how the growth of immigration differentially affects fixed shares of low- and high-wage natives.

Table 15 presents our estimates of immigrant-induced supply shifts by skill groups defined by percentiles of the native wage distribution. It indicates that immigrants are increasingly concentrated in the lower parts of the native wage distribution. For all immigrants, the table shows that the log relative supply contribution of immigrants to the bottom 20 percent of natives relative to the upper 80 percent increased from $0.030 \log$ point to $0.130 \log$ point between 1980 and 1995. The lower panel shows that immigrants who arrived since 1980 expanded the relative supply of the bottom 20 percent of native workers in 1995 by a similar amount, $0.094 \log$ point. Comparing these results with those in table 14, we conclude that the post-1979 immigration relative supply increment to less-skilled labor is modestly lower when measured relative to a fixed share of low-wage natives rather than relative to the declining share of high school dropouts. The contribution of recent immigrants to the relative supply of workers earning wages below the sixtieth native percentile is actually somewhat larger than the immigrant

70. Specifically, we adjust wages for differences in sex, age, and region. For each year, we run a regression of log hourly wages of U.S. natives on a quartic in age, a female dummy, an interaction of age and the female dummy, and three region dummies. We then sort both natives and immigrants by their adjusted log hourly wages (actual log hourly wage less the predicted wage from this native wage regression). 


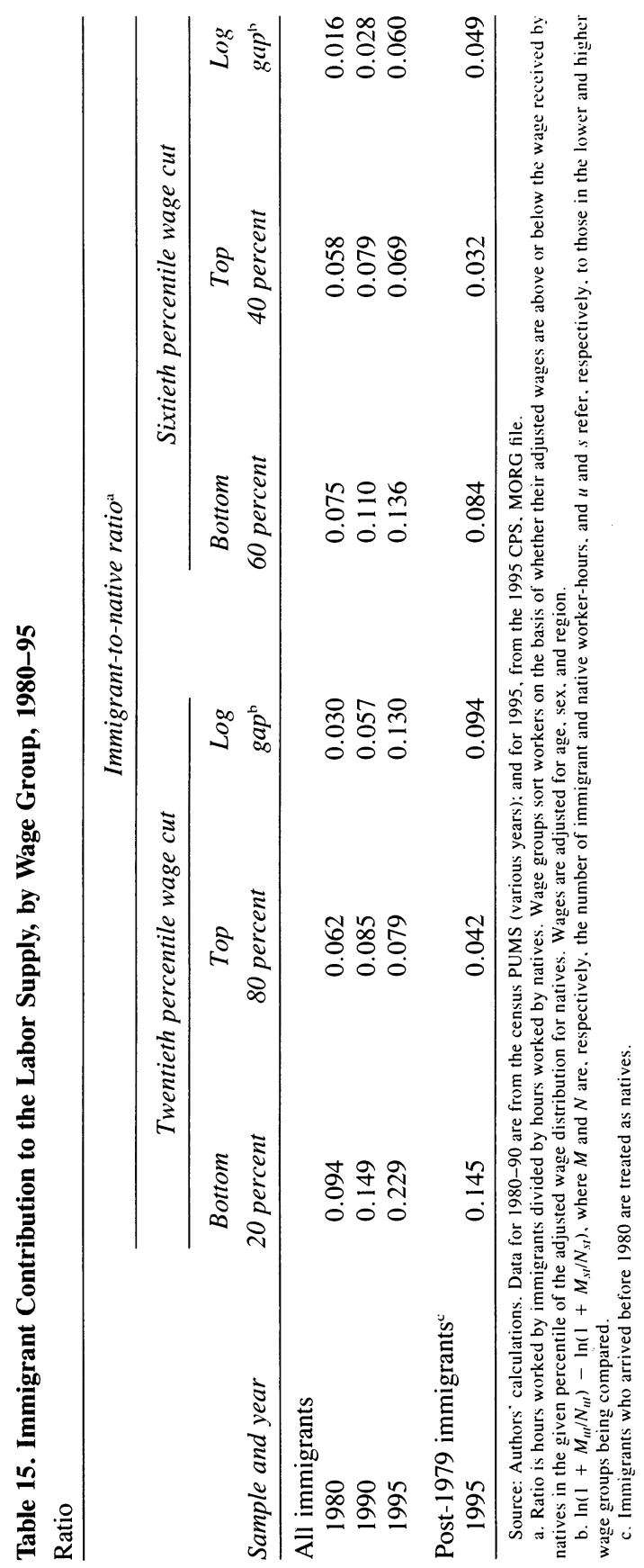


effect on the relative supply of high school equivalents, since a disproportionate number of college-educated immigrants earn relatively low wages.

Both the educational group and wage group approaches to measuring the effects of immigrants on relative skill supplies may overstate the effects of immigrant competition on low-skill natives. If immigrants and natives with similar education, or wages, or both operate in partially segmented labor markets, changes in immigrant supply may have little impact on native wages. The growing share of immigrants in the lower part of the native wage distribution may reflect declining labor market conditions due to immigrant crowding into a segmented immigrant labor market, rather than increased competition for low-wage natives. It is difficult to assess this alternative hypothesis within our framework. However, David Jaeger presents some aggregate and metropolitan arealevel data from the 1980 and 1990 censuses indicating that changes in the relative supply of immigrants to natives within sex-education groups have little effect on the immigrant-native wage gap for a given group. ${ }^{71}$ This evidence suggests that immigrants and natives may be nearly perfect substitutes in production within broad educational groups (as we assume in our education-based approach).

\section{The Effect of LDC Trade on Implicit Relative Labor Supplies}

We next examine the extent to which increased trade between the United States and less developed countries has implicitly augmented the relative supply of less skilled workers in the U.S. labor market. The growth of such trade has accelerated in the 1990s, with LDC imports as a percentage of GDP rising from 2.3 percent in 1980 to 2.8 percent in 1990 and to 4.1 percent in 1996. Trade in manufactures with less developed countries has the potential to affect less skilled U.S. workers adversely, since, as illustrated in table 4, LDC imports are concentrated in industries that disproportionately employ less educated workers and exports to LDCs are found in industries that are much more skill intensive. If the impact of LDC trade is concentrated on industries disproportionately employing high school dropouts, and if the appropriate skill coefficients to assess the effects of such trade on the nation's factor proportions differ greatly from the average skill coefficients used

71. Jaeger (1995). 
in most factor content studies, LDC trade may have a significant effect on the least skilled workers, whose relative wages have been falling sharply. ${ }^{72}$

We examine the implications of eliminating trade with LDCs in manufactures, using equation 18 under different assumptions concerning the skill-intensity and productivity of U.S. production that would replace LDC imports. We first follow the standard practice of estimating the labor supply embodied in both LDC and developed country trade flows in a given year, using that year's average unit labor coefficients for different skill groups of U.S. production in the three-digit manufacturing industries in which the imports and exports arise. More precisely, we estimate the implicit labor supply (in efficiency units) of skill group $k$ embodied in trade in manufactures in year $t$ as

$$
T_{k t}=\sum_{l} e_{k l t} L_{l t} \frac{T R_{l t}}{S_{l t}}
$$

where $e_{k l t}$ is the proportion of group $k$ (in labor efficiency units) in industry $l$ in year $t ; L_{l t}$ is the total labor efficiency units used in industry $l$ in year $t$; and $T R_{l t} / S_{l t}$ is the ratio of imports less exports to shipments for industry $l$ in year $t$. The proportional impact of trade on the labor supply of skill group $k$ in year $t$ is then given by $T_{k t} / L_{k t}$ where $L_{k t}$ is the total efficiency units of group $k$ (both natives and immigrants) employed in the aggregate U.S. labor market in year $t .^{73}$

We examine imports by source country and exports by receiving country for manufactures measured at the three-digit industry level. We classify western European countries (except Greece and Portugal), Australia, New Zealand, Japan, and Canada as developed countries and we include U.S. trade flows with all other countries in the LDC trade flow aggregate.

Table 16 shows the effect of LDC and developed country trade on

72. Thus analyses that aggregate workers into categories such as high school and college equivalents or production and nonproduction workers and assume that LDC imports displace domestic production at average current sectoral factor ratios (for example, Sachs and Shatz, 1994; Krugman, 1995a; and Lawrence, 1996) may understate the impact of LDC trade on the smaller but highly exposed group of least skilled workers (that is, high school dropouts).

73. Since overall U.S. trade and trade with LDCs in manufactures are not balanced, we implicitly assume that any scale (aggregate demand) effects of trade deficits have skill-neutral effects on labor demand. 


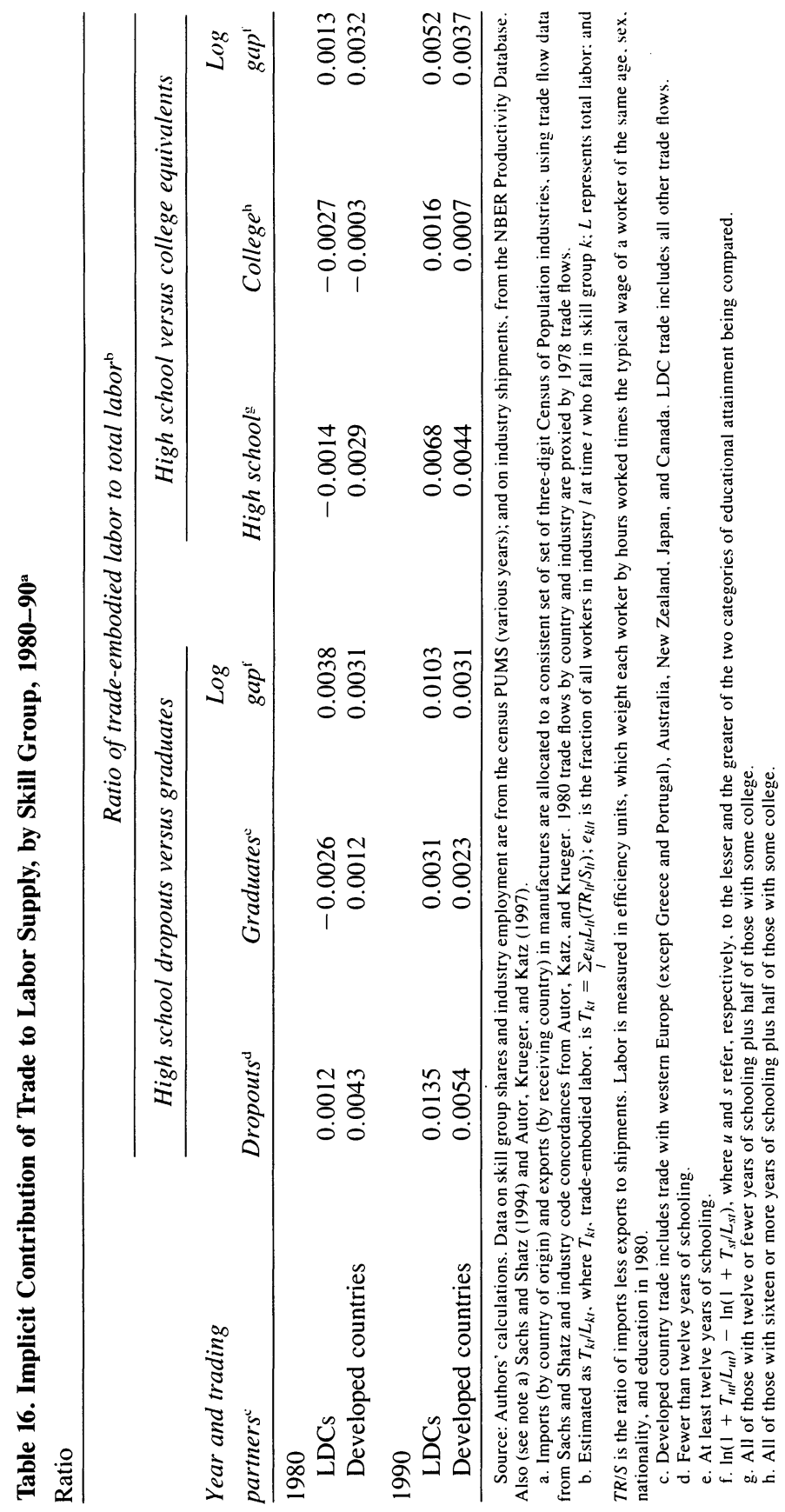


labor supply by education in 1980 and 1990, using the contemporary average unit labor coefficients and following the approach of equation 18. The implicit relative labor supply effects of trade are quite small in 1980 and increase only modestly (0.007 log point) from 1980 to 1990. There is no noticeable change in the impact of trade with developed countries on relative labor supplies in this period. We therefore conclude that it is likely that any possible "action" in trade's impacts on different skill groups in the United States will be found in the growing trade with LDCs-specifically, in the surge of 1990-95and will only be substantial if LDC trade displaces activities that use less skilled labor much more intensively than is reflected in contemporary industry average labor skill coefficients.

Table 17 presents estimates of the implicit effect of LDC trade on labor supply by skill in 1980, 1990, and 1995, under three alternative counterfactuals: "low," "middle," and "high". In all three counterfactuals, we assume that the reduction in domestic production from the elimination of exports to LDCs would occur at contemporary industry average skill shares and labor productivity. Andrew Bernard and Jensen document that exporting plants are more productive and employ a substantially larger share of more skilled (nonproduction) workers, on average, than other plants within the same four-digit industry. ${ }^{74}$ The marginal production affected by reductions in exports is likely to be that of plants in the lower part of the skill and labor productivity distribution of exporting plants. The average skill shares and productivity in the industry may be a reasonable proxy for these marginal exporting plants. The low counterfactual follows table 16 in assuming that imports and exports both embody labor supply at contemporary industry average skill intensities and productivity. The middle counterfactual assumes that the implicit labor efficiency units from LDC imports in each threedigit industry are replaced by domestic production using production methods lagged by ten to fifteen years, which typically utilize a larger share of less educated labor than contemporary industry average skill shares. The high counterfactual assumes that domestic production replaces LDC imports by using average industry skill shares and labor productivity from 1970 (before the growth of LDC imports in manufactures), and that consumers have inelastic demand for the goods, so

74. Bernard and Jensen (1995). 


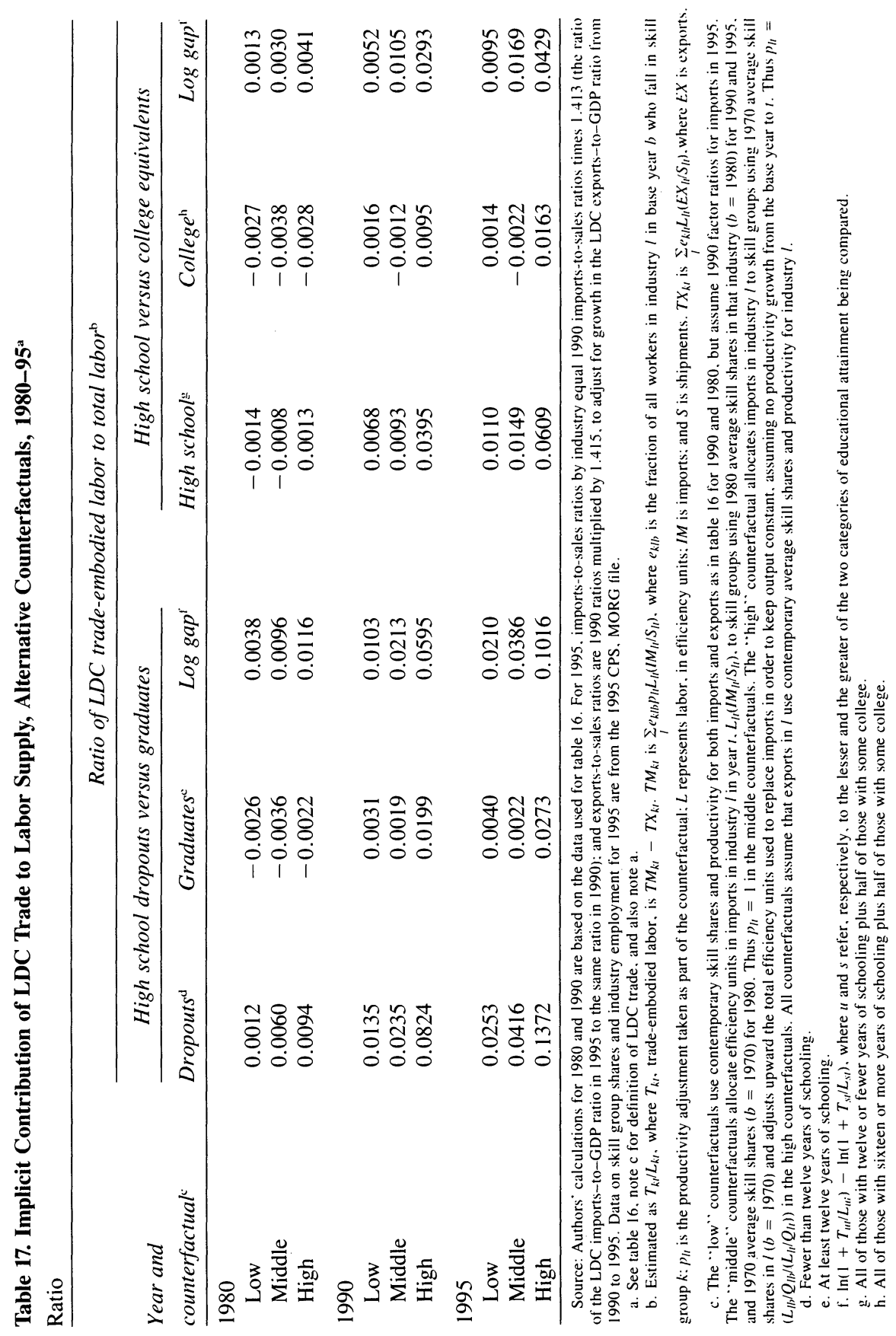


that the increase in domestic output to replace imports equals the real output contained in imports. The assumptions of no technological progress since 1970 and inelastic consumer demand are extreme. We believe that the middle counterfactual is the most realistic of the three.

The estimates of the impact on relative labor supplies of LDC trade under the middle and high counterfactuals in table 17 suggest much greater effects of the growth of LDC trade on educational wage differentials than does the assumption that LDC trade displaces domestic output at current average unit labor input coefficients. The middle and high counterfactuals imply that LDC trade augmented the relative supply of dropouts by 0.04 to $0.10 \log$ point in $1995 .{ }^{75}$ Under these assumptions, the elimination of LDC trade in 1995 would have increased the relative wage of dropouts by 0.012 to $0.033 \log$ point, given our assumed relative wage elasticity of -0.322 . The effects are larger than in table 16 , but still modest, for the supply of high school equivalents relative to college equivalents under our preferred middle counterfactual.

\section{Summarizing the Contributions of Immigration and Trade}

Table 18 summarizes our aggregate factor proportions estimates of the contributions of the post-1979 immigration and LDC trade shocks to changes in educational wage differentials from 1980 to 1995 , under different assumptions about the responsiveness of relative wages to changes in relative skill supplies. We examine the counterfactual of cutting off all immigration and all growth in trade flows with LDCs in January 1, 1980. Thus we present the implied wage effects of 1995 changes in skill supplies of immigrants who arrived after 1979 and of the implicit labor supplies embodied in the change in LDC trade flows between 1980 and 1995.

75. Our estimates of the effects of LDC trade on the implicit relative supply of high school dropouts in 1990 under the high counterfactual are roughly similar to Wood's (1995) estimates of the impact of LDC trade on unskilled workers for the same year, using adjusted LDC-based labor input coefficients. Wood estimates that LDC trade reduced the demand for skilled relative to unskilled workers in manufactures by 21.5 percent $(0.20 \log$ point $)$. If we normalize our implicit labor supply effects of LDC trade in 1990 by labor efficiency units by skill group in manufacturing, rather than in the entire economy, we obtain an relative labor supply increasing effect (and relative labor demand decreasing effect) for high school dropouts of 18 percent $(0.165 \log$ point $)$. 
Table 18. Estimated Contributions of Immigration and LDC Trade to Growth in Log Wage Differentials, 1980-95

Log points, except as indicated

\begin{tabular}{|c|c|c|c|c|c|c|}
\hline \multirow{3}{*}{$\frac{\text { Item }}{\text { Assumed wage elasticity }}$} & \multicolumn{6}{|c|}{ Wage comparison } \\
\hline & \multicolumn{3}{|c|}{$\begin{array}{c}\text { High school graduates } \\
\text { versus dropouts }\end{array}$} & \multicolumn{3}{|c|}{$\begin{array}{c}\text { College versus high school } \\
\text { graduates }\end{array}$} \\
\hline & -0.2 & -0.322 & -0.4 & -0.5 & -0.709 & -1 \\
\hline Actual change, 1980-95 & 0.109 & 0.109 & 0.109 & 0.191 & 0.191 & 0.191 \\
\hline $\begin{array}{l}\text { Estimated contribution } \\
\text { Post-1979 immigration } \\
\text { LDC trade } \\
\text { Immigration plus trade }\end{array}$ & $\begin{array}{l}0.030 \\
0.006 \\
0.036\end{array}$ & $\begin{array}{l}0.048 \\
0.009 \\
0.057\end{array}$ & $\begin{array}{l}0.060 \\
0.012 \\
0.072\end{array}$ & $\begin{array}{l}0.007 \\
0.007 \\
0.014\end{array}$ & $\begin{array}{l}0.009 \\
0.010 \\
0.019\end{array}$ & $\begin{array}{l}0.013 \\
0.014 \\
0.027\end{array}$ \\
\hline $\begin{array}{l}\text { Percent contribution }{ }^{\mathrm{b}} \\
\text { Post- } 1979 \text { immigration } \\
\text { LDC trade } \\
\text { Immigration plus trade }\end{array}$ & $\begin{array}{r}27 \\
6 \\
33\end{array}$ & $\begin{array}{r}44 \\
8 \\
52\end{array}$ & $\begin{array}{l}55 \\
11 \\
66\end{array}$ & $\begin{array}{l}3 \\
4 \\
7\end{array}$ & $\begin{array}{r}5 \\
5 \\
10\end{array}$ & $\begin{array}{r}7 \\
7 \\
14\end{array}$ \\
\hline
\end{tabular}

This table highlights the fact that immigration has a much larger impact on U.S. native high school dropouts than does LDC trade. The impact of post-1979 immigrants on relative skill supplies can explain a 0.030 to $0.060 \log$ point decline ( 27 to 55 percent of the actual decline) in the relative wages of high school dropouts over 1980-95, depending on the wage elasticity chosen. Increased LDC trade, under our preferred middle counterfactual and the -0.322 wage elasticity, explains less than 10 percent of the declining relative wage of dropouts. The table also shows that immigration and LDC trade have similar, relatively modest effects on the college-high school wage differential. In combination, they probably account for no more than 10 percent of the large, $0.191 \log$ point increase in this differential from 1980 to 1995.

This paper asks how much immigration and trade affect labor market outcomes. Our answer is that the impact of increased immigration and LDC trade on the labor market does not explain much of the increase in the college wage premium or overall wage inequality in the United States. Other factors-such as an acceleration of skill-biased technological change, a slowdown in the growth of the relative supply of 
college graduates, and institutional changes in the labor market-are probably more important than immigration and trade in explaining the widening of the U.S. wage structure since the late 1970s. But the concentration of immigration and trade at the lower end of the skill distribution does explain an important part of the decline in the relative wage of high school dropouts. The reason is that a disproportionate share of immigrants has less than a high school education, and a disproportionate and rising share of imports is from sectors that employ such workers. Moreover, as in our earlier work, we find that immigration has a larger impact on less educated workers than does trade. ${ }^{76}$

\section{Toward a Full Accounting of the Effects of Immigration}

In standard models of immigration and trade, the income losses of natives who compete with immigrants or with imports are more than matched by the income gains of natives whose skills or capital complement those of immigrants or of imports. How large might these effects be? Since capital is a likely beneficiary of immigration, we take a step toward a fuller accounting of the distributional effects of immigration by extending our two-input (skilled and unskilled labor) model to incorporate capital as a third factor. We use this extended model to simulate the distributional and efficiency impacts of the post-1979 immigration flow and to check whether the conclusion that immigration explains much of the declining relative wage of high school dropouts holds up in such a framework. ${ }^{77}$

Suppose that one can represent the U.S. economy by an aggregate production function $f[K, b N,(1-b) N]$, where $K$ is capital, $N$ gives the number of workers, and $b$ gives the fraction of workers who are skilled. We assume that the production function has constant returns to scale and that natives own the capital stock. Then in a preimmigration regime, the national income accruing to native workers is

$$
Q_{N}=f_{K} K+f_{S} b N+f_{U}(1-b) N \text {, }
$$

76. Borjas, Freeman, and Katz (1992).

77. We concentrate on immigration both because our analysis suggests that the distributional effects of immigration are larger than those of trade and because the persistent trade imbalances and large volume of intraindustry trade mean that a full accounting of trade's effects would take us far beyond the labor market focus of this paper. 
where $f_{i}$ is the marginal product of input $i$, and $S$ and $U$ represent skilled and unskilled labor, respectively. The total increase in national income accruing to natives when the United States admits $M$ immigrants equals

$$
\Delta Q_{N}=\left(K \frac{\partial f_{K}}{\partial M}+b N \frac{\partial f_{S}}{\partial M}+(1-b) N \frac{\partial f_{U}}{\partial M}\right) M .
$$

Assume that a fraction $\beta$ of immigrants are skilled. Suppose, initially, that capital is infinitely elastic, so that $\partial f_{K} / \partial M$ is zero. Then if $\beta$ equals $b$, immigration does not alter the relative factor ratio in the United States and natives neither lose nor gain from immigration $\left(\Delta Q_{N}\right.$ is zero because all the terms in equation 21 vanish). Because the price of capital is fixed, immigration can only affect native incomes when $\beta$ does not equal $b$. The United States has been admitting immigrants who, on average, are less skilled than native workers. Thus $\beta$ is less than $b$, and there are both gains and losses from immigration; the winners are the skilled workers and the losers are the unskilled workers. The net gain to natives, however, is positive. ${ }^{78}$

Some studies of immigration assume that the capital stock (rather than the price of capital) is fixed. In this case, there would be a net gain to the United States from immigration, even when $\beta$ equaled $b$. The gains would accrue to native-owned capital. In terms of equation 21, $K \partial f_{K} / \partial M$ would be positive, and the gains to skilled and unskilled workers would depend on the own effects of shifts in supply, as well as on the cross-effects among the three inputs.

Equation 21 can be evaluated numerically if one makes assumptions about the responsiveness of factor prices to an increase in immigrant labor supply. We simulate the model in this equation by using the two polar assumptions about capital and a set of assumptions about the responsiveness of factor prices to immigration. In particular, let $\epsilon_{i j}$ be the factor price elasticity $\partial \ln f_{i} / \partial \ln X_{j}$, where $X_{j}$ is the quantity of input $j$. Daniel Hamermesh surveys an extensive literature that attempts to estimate these elasticities. ${ }^{79} \mathrm{We}$ used a variety of assumptions about these elasticities from the range that he provides. The simulation pre-

78. Borjas (1995) discusses the economic benefits from immigration using this framework and presents a more detailed discussion of the algebra underlying the simulations presented below.

79. Hamermesh (1993). 
Table 19. Simulated Costs and Benefits of Post-1979 Immigration ${ }^{a}$

\begin{tabular}{lcc}
\hline Item & $\begin{array}{c}\text { Holding price } \\
\text { of capital fixed }\end{array}$ & $\begin{array}{c}\text { Holding capital } \\
\text { stock fixed }\end{array}$ \\
\hline Percent change in earnings & & \\
$\quad$ Capital & $\ldots$ & 6.50 \\
$\quad$ Skilled native workers & 0.35 & -2.49 \\
$\quad$ Unskilled native workers & -4.64 & -4.57 \\
Percent change in skilled-to-unskilled earnings ratio & 4.99 & 2.08 \\
Percent change in total native earnings & 0.05 & 0.13 \\
Dollar GDP gain, assuming \$7 trillion GDP & 3.5 billion & 9.1 billion \\
\hline
\end{tabular}

Source: Authors' calculations based on model described in text. Data on factor GDP shares are from Autor. Katz, and Krueger (1997, table A1).

a. Changes relative to counterfactual of no immigration after 1979.

sented below uses estimates from the upper end of this range. Simulations based on smaller estimates yield both miniscule benefits and miniscule costs of immigration. In particular, we assume that $\epsilon_{s s}=-1.5$, $\epsilon_{U U}=-0.8$, and $\epsilon_{S U}=0.05 .^{80}$ This assumption builds capital-skill complementarity into the calculations.

The simulation requires estimates of the parameters $b$ and $\beta$, as well as of the share of income accruing to each of the factors. We estimate these parameters from the 1995 CPS, MORG files. We define skilled workers as those having at least a high school education and unskilled workers as high school dropouts. The 1995 CPS then implies that $b$ is 0.91 and $\beta$ is 0.68 for immigrants who entered after 1979 . We make the standard assumption that the labor share of income (for all workers) is 0.7 . Using data from the study by Autor, Katz, and Krueger, we estimate that the skilled worker share of GDP is 0.661 and that of unskilled workers is $0.039 .{ }^{81}$ Finally, we need an estimate of the immigrant supply shock. The 1995 CPS implies that post- 1979 immigrants increased labor supply, in terms of full-time equivalent workers, by 5.5 percent.

Table 19 reports the simulation results, using both polar assumptions about capital. The first column of data gives the results when we assume that the price of capital is fixed (so that capital adjusts completely to the entry of immigrants). In this case, unskilled workers suffer a 4.6

80. These assumptions determine all the other elasticities in the model, because of the mathematical property that the relevant weighted average of factor price elasticities is zero.

81. Autor, Katz, and Krueger (1997, table A1). 
percent decline in earnings, whereas skilled workers gain about 0.4 percent. This produces a change in the relative wage of these two groups of 5.0 percent, the same magnitude as estimated in our middle case in table 18. This redistribution generates a net gain for the U.S. economy of 0.05 percent of GDP, or roughly $\$ 3.5$ billion per year in a $\$ 7$ trillion economy. The second column gives the results when we assume that the capital stock is fixed. In this case, the main beneficiary of immigration is native-owned capital. The capitalists experience a 6.5 percent increase in income, while both skilled and unskilled workers suffer losses: 2.5 percent and 4.6 percent, respectively. The wage of skilled relative to unskilled workers changes by 2.1 percent. The net gain to the economy is 0.13 percent, which roughly translates into $\$ 9.1$ billion a year. The simulation therefore reveals that the economic gains from immigration are small in such a massive economy. ${ }^{82}$

It is worth emphasizing that this simulation assumes that all workers within a given skill group are perfect substitutes. A more general analysis would take into account complementarities that might exist between some immigrants (such as those with fewer than nine years of schooling or those with specialized training) and some native workers. Such complementarities would increase the gains to the U.S. economy from immigration. A more complete model would also allow for gains from increased product variety associated with immigration. But our estimates may also overstate the "true" gain because they ignore the possibility that trade would substitute for immigration if fewer immigrants had entered the country. The bottom line from our simulations is that the economic impact of immigration is mainly redistributional and primarily affects a small group of the least educated U.S. native workers.

\section{Conclusions}

In the past two or three decades there has been a substantial growth in immigration and trade between the United States and the less developed countries. The large flow of less educated immigrants from LDCs and the rapid growth in U.S. imports of LDC manufactured goods has

82. Johnson (1997b) concludes from a similar but more detailed analysis that the effects of immigration on the national economy are even smaller than our estimates. 
increased the effective supply of less educated labor relative to more educated labor in the United States. This, in turn, has raised questions about the potential contribution of trade and immigration to the rise in the wage differential between more and less educated workers.

Determining the effects of immigration and trade on economic outcomes is difficult. It is difficult because immigration and trade may have an effect on national labor market outcomes without greatly affecting relative outcomes in the regions most immediately touched by trade flows or immigrant flows. It is also difficult because many other factors affect the U.S. job market; without adequate controls for those factors, the influence of immigration or trade can be hard to discern in a given body of data. And, most important, it is difficult because one must specify a realistic counterfactual of how the economy would have developed, how native labor would have acted, and how firms would have produced goods, in the absence of the relevant immigration or trade flows. These counterfactuals, in turn, require good estimates of the magnitudes of various economic parameters.

In this paper, we try to specify appropriate counterfactuals and to quantify the potential effects of immigration and trade with different estimated or postulated parameters. We conclude that the effects of immigration and trade flows on relative skill supplies have not been substantial enough to account for more than a small proportion of the overall widening of the wage structure over the past fifteen years and have played only a modest role in the expansion of the college-high school wage differential in the United States. Under various plausible specifications, the main adverse effect of immigration and trade on U.S. native outcomes falls on workers with less than a high school education: the combined effects of immigration and trade may explain half of the decline of the relative wages of high school dropouts since 1980. Immigration has a particularly large impact on the outcomes for these workers because the flow of less educated immigrants into the country has been substantial; immigration increased the relative supply of workers with less than a high school degree by 15 to 20 percent over the period 1980-95. Increased trade from LDCs appears to have been much less important than immigration for the relative earnings of low-wage U.S. workers. 


\section{Comments and Discussion}

John DiNardo: Trade and immigration policy are each small aspects of a broader issue: how do we, or the government, treat those who happen to have been born outside the geographic boundaries of the United States? Given the scope of the subject, it should not be surprising that economists can play a small role, at best, in informing the larger issues that the question implies.

Moreover, when one asks the more narrow question-what has been the impact of immigration and trade on the economic well-being of the native-born worker? - the implied ceteris paribus, holding other political and economic institutions constant, is quite important. One might well expect increased immigration or trade to have very different consequences under very different institutions. Even defining the issue narrowly in this way leaves many questions of interest to economists.

This contribution by George Borjas, Richard Freeman, and Lawrence Katz elaborates substantially on their previous work: they undertake to develop a conceptual model that seeks, inter alia, to explain the degree of wage inequality experienced by both the U.S. native-born and by immigrants to the United States. The paper paints with a broad brush. The period 1960-90 has seen a great deal of change that has made an impact on labor markets: the rise of civil rights and women's rights movements and the decline of unionism, to name a few. Borjas, Freeman, and Katz, among themselves, have documented the effect of many of these changes in other research; here they train their focus on the impact of trade and immigration on the structure of wages.

My focus is the authors' critique of other researchers' work on im- 
migration. A substantial portion of the paper is a critique of what Borjas, Freeman, and Katz refer to as area studies; notably, work by Joseph Altonji and Card, Robert LaLonde and Robert Topel, and Robert Schoeni that provides evidence against the view that recent immigration has disadvantaged native-born workers. ${ }^{1}$ The paper also reexamines issues analyzed in related work by Kristin Butcher, Card, Frey, and Liaw. ${ }^{2}$ Because of the quality of the empirical work in the present paper and in the others cited, it is easier than usual to focus more on what the facts mean than on what the facts are. Indeed, this paper and those that it critiques have several "facts" in common! In particular, all agree that wage changes across states, cities, or other regions and over time have essentially been uncorrelated with the changes in the number or fraction of immigrants living in a particular place. Further adding to the muddle for a dispassionate outsider, although Borjas, Freeman, and Katz critique area analyses, they bolster their case with an area analysis of their own.

Where, then, is the disagreement? In this paper Borjas, Freeman, and Katz seem to differ from other researchers in answer to the following question: how much of the observed disparity in economic status can be parsimoniously described as the outcome of shifts in the relative demand and supply of workers of different "skills" - that is, years of work experience and formal education -in a competitive labor market? To answer this question, the authors' aggregate proportions approach and the area analyses it critiques focus on a relationship of the following sort:

$$
\Delta \ln \left(\frac{w_{s t}}{w_{u t}}\right)=-B \Delta \ln \left(\frac{x_{s t}}{x_{u t}}\right) .
$$

Here, $B$ is a parameter, $x$ denotes total employment of skill group $s$ or $u$ at time $t, w$ denotes average wage, and $\Delta$ denotes that a time difference of the data has been taken. The aggregate proportions approach and area analysis differ somewhat from this simple framework. For example, on the one hand, the area analyses surveyed allow for a greater number of skill categories, and the variables are additionally indexed by standard metropolitan statistical area (SMSA) or city. On the other

1. Altonji and Card (1991); LaLonde and Topel (1991); Schoeni (1996).

2. Butcher and Card (1991); Card (1990, 1997); Frey (1995a); Frey and Liaw (1996). 
hand, the aggregate proportions approach includes "trade-embodied" employment in $x_{s t}$ and $x_{u t}$, and there are also other differences. Nonetheless, the theoretical models being assumed or tested share the following property: when the number of workers-measured as the proportion of workers of a given type-rises, the wage of those workers relative to other workers falls (or is predicted to fall).

How does this relate to the economic impact of immigration (or trade) on labor market outcomes? In both area analysis and the aggregate proportions approach, immigration and trade affect relative wages by changing the term on the right-hand side, $x_{s t} / x_{u t}$. For example, the simple model predicts that if the diversity of immigrant "types" matches the diversity of types among the native-born, immigration would have little or no effect.

The work that Borjas, Freeman, and Katz critique attempts to test this relationship by observing that immigrants do not settle uniformly across SMSAs or cities. The area analyses by Altonji, Card, and Schoeni compare the immigration-induced changes in the proportions of different skill types to changes in relative wages of these skill types across SMSAs. ${ }^{3}$ They find estimates that are small in magnitude; although fairly precise, these estimates are rarely different from zero at conventional levels of significance.

Likewise, in table 7 of the present paper, those specifications that are most analogous to these area analyses show much the same pattern. At levels of aggregation much broader than those used by Card and Schoeni, however, the estimates vary widely and sign patterns are inconsistent, with the standard errors generally rising as the geographic area under consideration becomes larger. (Due to the limitations of the census data, only relatively broad levels of aggregation can be straightforwardly compared across the entire period 1950-90.)

Notwithstanding these differences, Borjas, Freeman, and Katz, like Card, conclude that "immigration is not a major determinant of the regional structure of labor market outcomes for natives." They argue, however, that this finding should not militate against the conclusion that the inflows of foreign-born workers to the United States have been an important cause of the fall in the wages of workers with less than a high school education. Furthermore, given "plausible" estimates of

3. Altonji and Card (1991); Card (1997); Schoeni (1996). 
labor demand parameters, the simple supply and demand framework used in their simulations suggests that the wages of workers with less than a high school education may have been greatly affected.

Given the structure of the simplest supply and demand framework, one explanation for this finding is that immigration does not induce changes in the relative supplies of skill types across regions. That is, the small response observed on one margin (wages) might be the result of a big response on another (native migration). Indeed, if the elasticity of native outflow of skill type $k$ with respect to immigrant inflow of skill type $k$ is unity, and if the supply and demand model is a good description of the data, then zero measured wage effects across geographic areas is exactly what one would predict.

It would be quite surprising if this elasticity were large, as such "skating rink" migration is little noticed in the demographics or economics literature. Randall Filer observes that "there has been little previous work dealing with the relation between immigrant arrivals and native migratory patterns. ${ }^{4}$ In my experience, a large elasticity is hard to find.

Moreover, if native-born migration "undoes" the effect of immigration, it creates two new puzzles. First, as Borjas puts it, an "unresolved puzzle facing those who interpret the lack of correlation between immigration and native wages in the local labor market in terms of an economy-wide equilibrium process is clear: Why should it be that many other regional variations persist over time, but that the impact of immigration on native workers is arbitraged away immediately?" ${ }_{5}$ The empirical literature is replete with examples of regional shocks that appear to be persistent and resistant to migration arbitrage by the nativeborn. Evidence on the economic fortunes of displaced workers have consistently found enduring effects of labor market conditions at the time of displacement on wages, for example. Olivier Blanchard and Katz conclude that a one-time adverse shock reduces a state's real wage for up to ten years before internal migration reequilibrates wages. ${ }^{6}$

The second puzzle is the mechanism by which internal migration diffuses immigrant shocks. In the context of equation A1, internal migration mitigates the observed regional variation induced by immi-

4. Filer (1992, p. 245).

5. Borjas (1994, p. 1700).

6. Blanchard and Katz (1992). 
gration only to the extent that it undoes changes in skill shares. Yet Card finds that when low-skilled immigrants, for example, arrive in an SMSA, the proportion of low-skilled workers (both immigrant and native-born) in that SMSA rises slightly more than by one for one. ${ }^{7}$

Borjas, Freeman, and Katz take up this part of the puzzle in table 11, by attempting to test directly whether immigration changes factor proportions within a state. Using state-level data, they find that their results are quite sensitive to the "appropriate" choice of counterfactual. As a practical matter, this amounts to whether they employ first differences (comparing changes across adjacent censuses), "double differences" (comparing 1950-70 differences to 1970-90 differences), or double differences with an initial conditions control (a value for the proportion of a particular skill group in 1950).

The key parameter that the authors estimate in equation $11, d$, takes a value of one if native migration flow is unresponsive to immigration inflow, and zero if natives leave an area at a rate of one for one with an increase in the number of immigrants in that area. In this latter case, increased migration from abroad for a particular skill group is completely off-set by increased out-migration by natives, leaving skill ratios untouched. The authors' preferred specification (double differences with a control for 1950 skill levels) does include this latter case in conventional confidence intervals.

However, their estimates range from a high of 2.8 (with a standard error of 1.2) to a low of -0.34 (with a standard error of 0.30 ). Indeed, in more than half of their sixteen specifications, which they helpfully report, the coefficient is not significantly different from one. That is, an increased flow of foreign-born individuals has no migration effect on the native population. These can be contrasted with the results of Card, who, using finer geographic groupings, unrestricted city effects, and data from the period 1985-90, finds estimates of about 1.18 (with a standard error of 0.03 ) for a similar parameter, even after use of instrumental variables estimators. ${ }^{8}$

It is useful to recall the authors' statement regarding the attempt to find wage effects of immigration through area analysis: doing so is difficult " unless [one] can control for the forces that caused the regional

7. Card (1997).

8. See Card (1997). 
Figure A1. Distribution of Wages, 1979 and $1991^{\text {a }}$

Density

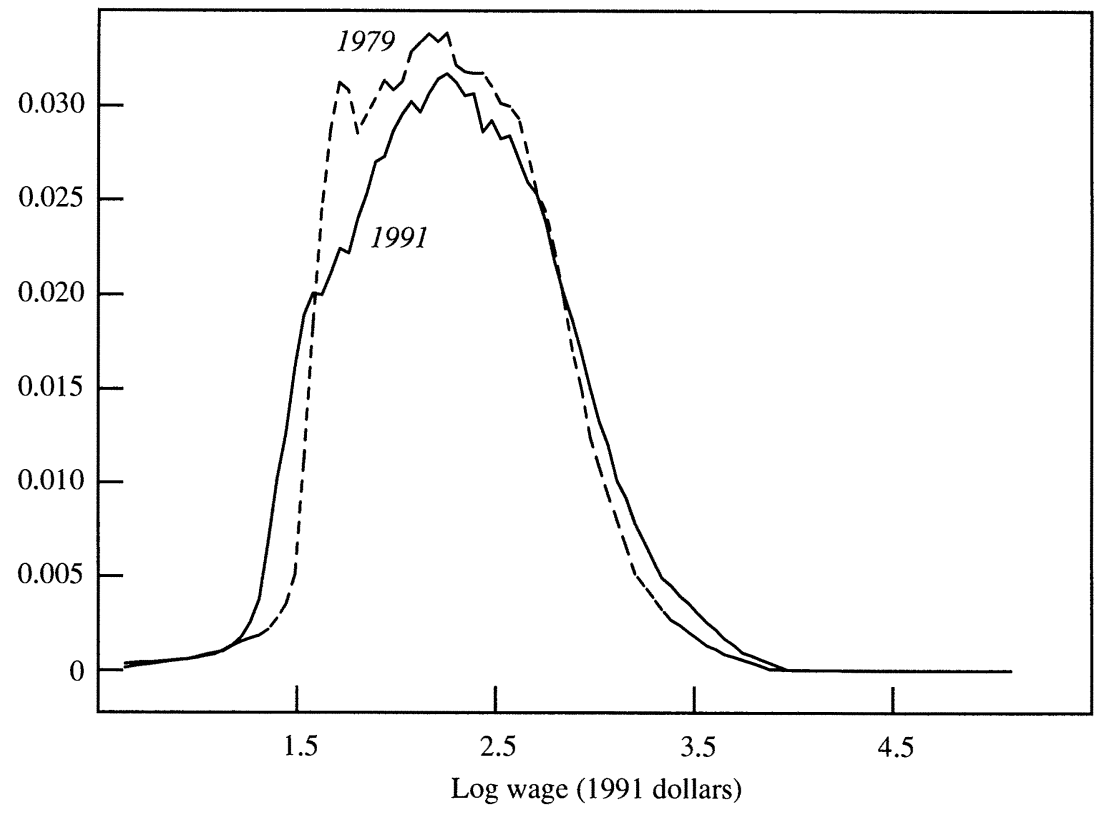

Source: Author's calculations based on data from 1979 and 1991 CPS, MORG files. a. Individual observations weighted by hours worked.

wage structure to change . . . over time." This argument would seem to apply with equal or more force in regard to migration across states over a forty-year time frame. Consider interstate migration during the period 1985-90. Florida, which Frey labels a high " internal migration" state, also received more foreign-born migrants than any state besides California and New York. ${ }^{9}$ The reasons for the native and foreign-born migrations are likely quite different and seem hard to uncover by looking at state-level data. For example, within Florida, Miami is clearly dominated by immigration from abroad, whereas metropolitan areas such as Tampa-St. Petersburg, West Palm Beach, Fort Meyers, and Daytona Beach are dominated by internal migration. Within California, Los Angeles saw the biggest increase in foreign-born residents and

9. Frey (1995a). 
Figure A2. Distribution of Wages, by Sex, 1979 and 1991 ${ }^{a}$

1979 distribution

Density

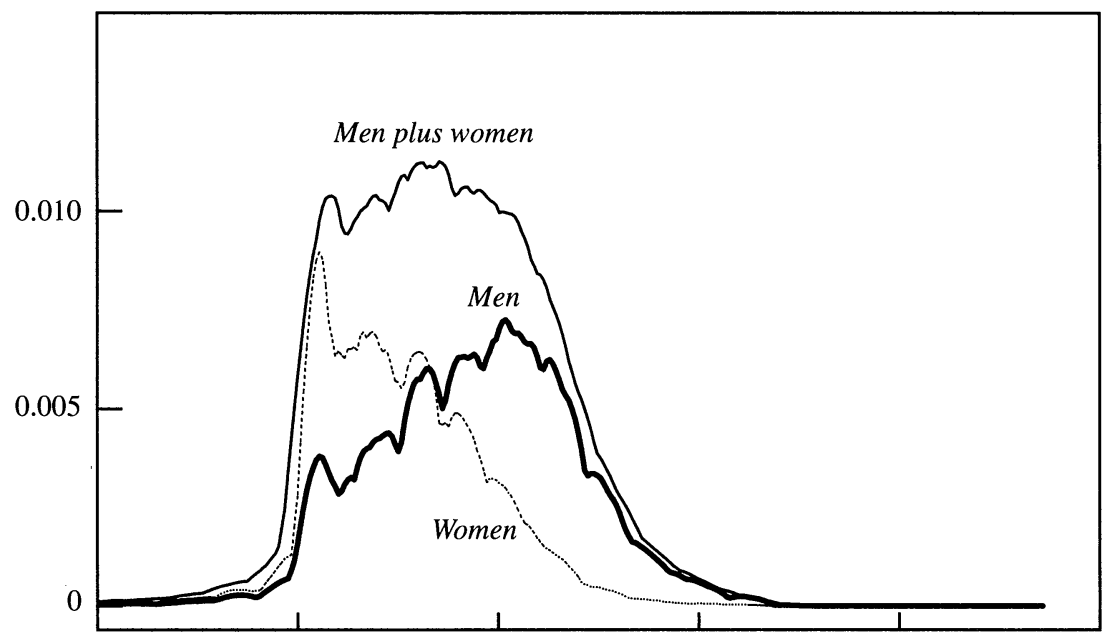

1991 distribution

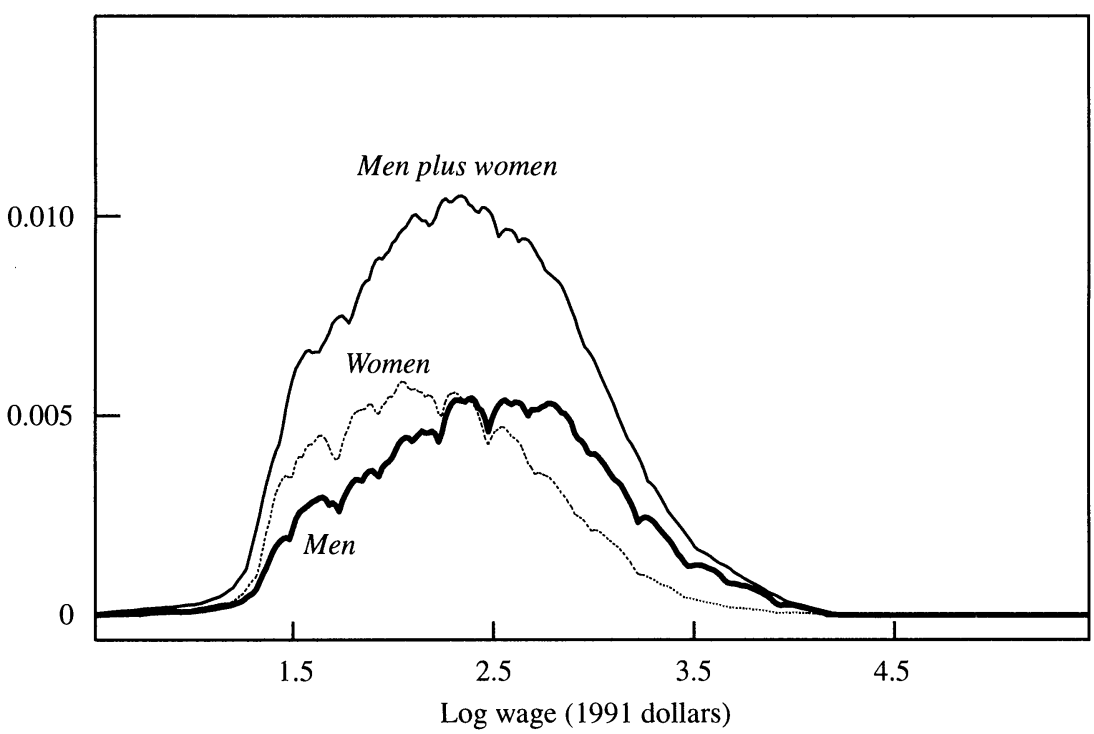

Source: Author's calculations based on data from 1979 and 1991 CPS, MORG files. a. Individual observations weighted by hours worked. 
substantial out-migration by natives. San Diego, by contrast, saw high levels of immigration by both the foreign- and the native-born.

Borjas, Freeman, and Katz do not overstate their results, and I do not wish to overstate this criticism. While some conflicting results seem potentially reconcilable-Card and Frey differ in their treatment of city fixed effects, for example-Filer's analysis is not as easy to reconcile. ${ }^{10}$ The evidence seems to suggest that a city or SMSA analysis with city fixed effects may be more appropriate than a state-level analysis with state fixed effects, but that is only one way of tying up disparate results. In short, although the authors' analysis of migration is helpful, I am not sure that it convincingly demonstrates that the United States is currently experiencing a "new white flight," as Frey describes it, nor that such a native-born migration is the reason why area analyses have not been able to find an effect of immigration on the wages of the native-born."

Even if migration arbitrage is not occurring, other mechanisms for arbitrage do exist. Indeed, the trade literature may provide insight into immigration literature, as it is flush with possible mechanisms that may have implications that can be tested in state-level or SMSA analyses. Schoeni finds evidence suggesting that relative prices of goods across SMSAs are empirically important in analyzing regional wage differentials. ${ }^{12}$ This seems a potentially fruitful area of inquiry.

As to the aggregate proportions approach, I am reluctant to conclude that it provides a more reliable way of predicting the impact of immigration on relative wages. The authors' simulations are based on the assumption that the principal mechanism by which immigration affects wages is shifting labor supply along a demand curve. Maybe this is correct; however, the approach provides no independent testable predictions. It can only be confirmed by the extent to which it is in accord with a priori beliefs about the size and directions of the effects. Sharp tests of the general-equilibrium approach taken in the paper are rare, perhaps largely because they are difficult or impossible.

I have one final concern, regarding the "macro" facts about wage inequality that need to be explained. This concern stems from important differences in the evolution of the distribution of wages for men and

10. Card (1997); Frey (1995a); Filer (1992).

11. Frey (1994).

12. Schoeni (1996). 
women. In my own work with Kristin Butcher, we find that the patterns of wages changes for the native-born relative to those for immigrants since the late 1970 s (the period in which changes in wages and immigration have been most dramatic) are quite different for men and women. ${ }^{13}$ Several of the authors' findings are suggestive of this fact. Perhaps, as they suggest, the more comparable treatment of women and men since the popular upheavals that began in the 1960s have played a role.

Recent work by Nicole Fortin and Thomas Lemieux provides further indication of important differences in the evolution of men's and women's wages. ${ }^{14}$ They find, for example, that when men's and women's wages are examined together, inequality in wages has changed very little since the late 1970s, apart from a minimum wage effect. Figure A1 presents estimates of the distribution of (hours-weighted) log wages in 1979 and 1991 (in 1991 dollars) for men and women together, based on CPS, MORG data. Figure A2, which displays wage distributions by sex, makes clear that the modest change depicted in figure $\mathrm{A} 1$ is the result of very different changes in the distributions of men's and women's wages.

In sum, the common thread of this paper and the research that it critiques appears to be that the increase in the foreign-born population can, at best, explain a small portion of the changes depicted in these figures and other changes in the wage structure over the period 196090. As the authors suggest, theirs are not the "final words." However, by carefully laying out so many new facts and reexamining some old ones, they have raised some new questions that deserve answers.

John M. Abowd: In contrast to DiNardo, I have something to say about the trade segment of this paper. Nevertheless I, too, focus my attention on the immigrant side of the paper.

One can think of this paper as the authors' attempt to resolve some of the questions that they raise in their 1996 paper for the American Economic Review and, earlier, in their 1992 paper; and, indeed, some of the questions that each of them raise in a variety of research on this subject.' What they are trying to do in the immigration section of this

13. Butcher and DiNardo (1997).

14. Fortin and Lemieux (1996).

1. Borjas, Freeman, and Katz $(1992,1996)$. 
paper-and I wish that I could interpret the trade section the same way-is to press hard on the data to find an empirical or natural experiment that they can use to assess the labor market effects of immigration in the United States. In their own words, the object of their 1996 paper is to estimate the effect of immigration on native labor outcomes, which depends critically on the empirical experiment used to assess immigration. Thus one can think of the current paper as a serious assessment of a variety of ways of thinking about that natural experiment.

The conclusion that one's measure of the effects of immigration depends on the type of natural experiment used was a direct consequence of finding that cross-sectional analyses for native wage rates in the 1980 and 1990 census produce very different estimated effects for males. The authors' attempts to explain these differences, using the changes between the two censuses, also failed. The early tables of the present paper confirms these conclusions. The authors now claim that area-based studies of immigration effects, such as their earlier papers and a large number of papers that DiNardo mentions, miss the mark because there is consistent evidence that the effects of immigration to a specific geographic area are diffused to the rest of the economy.

In the present paper, the authors also attempt to refine their earlier estimates of the aggregate effects on implicit labor supply from net trade. In this regard, I think that their conclusions, although subjected to more sensitivity analyses than the conclusions of their early work, are not greatly modified. They do not address some of the criticisms that have been leveled at that technique, but they know this. If one accepts their view of the way in which international trade affects domestic factor markets - that is, factor price equalization does not occur in the labor market-their diagnostics are reasonably convincing.

My brief summary of the paper is as follows. First, the total gain to U.S. GDP from immigration is trivial. Specifically, the net gain to the economy is somewhere between $\$ 3.5$ billion and $\$ 9.1$ billion on a $\$ 7$ trillion economy. But the redistributional effects, according to the authors' methods of assessment, fall almost entirely on unskilled workers and are responsible for about 40 percent of the real wage decline of high school dropouts compared with those with at least a high school diploma. That is a significant finding. The paper emphasizes that this is a good ballpark estimate for the redistributional effects of immigration on the right target group. 
Although there is no attempt to estimate the total gain to U.S. GNP from trade, the estimated redistributional effects account for only about 8 percent of the real wage decline of high school dropouts compared with those with at least a high school diploma. So, the trade effects are considerably smaller than those of immigration; and that is not inconsistent with their earlier work on the subject, although it is inconsistent with some of the work that has been produced by some of the authors' competitors.

From the analysis of wage gains for those with a college degree or more, compared with those with a high school diploma, the effects of immigration and trade are found to be roughly comparable, with the same orders of magnitude, but very small-only about 5 percent in the authors' preferred estimate-and the variation in these effects is much smaller. I think it would be fair to say that they conclude that for the groups above the lowest skilled group, the effects of trade and immigration are relatively modest.

The section on immigration and the distribution of wages lies the heart of the new analyses that are presented in the paper. The starting point is the observation that area-based immigration studies find very different results, depending on their specification and time period. In postmodern terminology, this conundrum reflects the need to be precise about the counterfactual and the natural experiment-although, economists used to say just that the conclusion was sensitive to the dates or to the functional form of the regression analysis.

In the area studies, it is well documented that six states have received essentially all of the immigrants for decades: California, New York, New Jersey, Texas, Illinois, and Florida. The authors' wrinkle here is to document that one can form a natural experiment by comparing California to either the other immigrant-receiving states or all other (nonimmigrant) states. In their natural experiment, the authors apply a slightly different treatment to California, to all the other immigrantreceiving states, and to all the other states.

Consider table 8, which reports the regional distribution of native and immigrant populations since 1950 . This table shows that the percent of all immigrants in the United States living in California rose from 10.4 percent in 1950 to 33.8 percent in 1990 . Over the same period, this proportion fell slightly (from 44.4 percent to 40.0 percent) in the other immigrant-receiving states and dramatically (from 45.2 percent 
to 26.1 percent) in all other states. From 1950 to 1970 the percent of all U.S. natives living in California also rose (from 6.9 percent to 9.6 percent), whereas it was stable in the other immigrant-receiving states (25.4 percent to 26.2 percent) and fell slightly in the other states (from 67.7 percent to 64.2 percent). In the period 1970-90, the percentages of the native-born population in each of the three regions was essentially stable. That fact is critical for the way that the authors formulate the natural experiment at this aggregated level.

These facts motivate an analysis that asks what the labor markets in California, in the other immigrant-receiving states, and in the other states would have looked like if the 1970-90 immigration shock had not occurred and the native population growth rates over this period mirrored the growth rates in the 1960 to 1970 period. This restatement of the counterfactual is important for reasons documented in tables 6 and 7 . These two tables show that immigrant flows into the different areas and education cells, which are the formalization of using California and the other immigrant-receiving states as the treatment groups for the natural experiment, do not have a consistent relation to the changes in native earnings. This is the authors' way of summarizing the fact that the shock-viewed as a shock to the area labor market or the area skilled labor market-has no consistent, predictable effect on the earnings of the shocked groups within those areas.

In particular, table 7, which reports the results of estimating equation 4 , shows that the area-education shock in immigration has a measured association with the adjusted change in the area-education earnings and employment outcomes that shows no consistent pattern. Think of table 7 as the authors' best attempt to control for other factors in the change analysis. Here, one treats the shock to the area education-specific market as coming directly from the immigration of comparably skilled people into the labor market.

The authors correctly interpret the widely varying coefficients, which confirm the visual conclusion from the simple natural experiment in table 6 , as implying that interpreting an area education increase in the immigrant population as a labor supply shock to an area education labor market is simply inconsistent with the data.

Table 8 restates the counterfactual. It is important to understand the full implications of table 8 and the associated regression analysis in table 9 . In equations 5 and 6 , the authors express the simple annual 
growth rate in an area's labor supply as the sum of the component due to natives, $\Delta n_{j}\left(t, t^{\prime}\right)$, and the part due to immigrants, $\Delta m_{j}\left(t, t^{\prime}\right)$, for area $j$ between years $t$ and $t^{\prime}$. They then ask, in equation 8, whether the change in the annual native contribution to the population growth rate in area $j$ between the periods $1960-70$ and $1970-90$ is related to the change in the immigrant contribution between the same periods. The regression analysis in table 9 confirms that there is a strong negative relation between these two changes in growth rates, which the authors interpret as implying that declines in native population growth in the different area markets exactly off-set the immigration shock in those markets. The offset is relative to the preexisting trend in native population growth in the market, rather than to a "no growth" counterfactual. So, this is their restatement of the critical natural experiment.

What does this imply for the simple natural experiment involving the three regional groups (California, other immigrant-receiving states, and all others)? Based on data in tables 1 and 8 and some population totals for the United States, one can compute that the population of the state of California grew at a simple rate of 3.4 percent over the period 1960-70 and at exactly the same rate over the period 1970-90. The native contribution over the period $1960-70, \Delta n_{C A}(60,70)$, is 2.9 percent, and the immigrant contribution, $\Delta m_{C A}(60,70)$, is 0.5 percent. The other immigrant-receiving states grew at a simple rate of 1.7 percent over this period, purely as a result of growth in the native-born population. And the other states grew at 1.5 percent (1.6 percent from natives and -0.1 percent from immigrants). Over the period 1970-90, California continued to grow at the simple annual rate of 3.4 percent, now comprising 1.7 percent natives and 1.7 percent immigrants. Hence the difference in the native contribution to the population growth rate, $\Delta n_{C A}(70,90)-\Delta n_{C A}(60,70)$, is -1.2 percent, and the associated difference in the immigrant contribution shocks, $\Delta m_{C A}(70,90)-$ $\Delta m_{C A}(60,70)$, is 1.2 percent. For the other immigrant-receiving states, the difference in the native growth rate contribution is -0.3 percent, and the difference in the immigrant contribution is 0.5 percent. Finally, for all other states, the difference in the native contribution to the growth rate is 0.0 percent and the difference in the immigrant contribution is 0.2 percent.

In greatly simplified form, this illustrates the authors' point: the native growth rate changed in an equal and off-setting manner. Hence 
there was no shock to the area labor markets. Rather, natives who would otherwise have been in the immigrant-receiving areas (especially California) diffused through the rest of the country. The authors' method implies that over the twenty-year period from 1970 to 1990, approximately 3.4 million native-born Americans stayed where they were rather than migrate to California, and an additional 2.0 million nativeborn Americans stayed where they were rather than migrate to the other immigrant-receiving states. I strongly suspect that the authors knew this before they conducted the rest of the analysis, and it strongly motivated the functional forms that are found in table 9.

Having estimated the effects of immigration, the authors turn to trade, continuing their earlier approach of trying to estimate the implicit increase in domestic labor supply from net trade flows. The main improvements over their 1996 paper are the attempt to estimate the flows by source (LDCs versus developed countries) and the use of microdata at the establishment level to distinguish the production technologies of plants within a given industry. These improvements permit them to calculate the implicit labor supply of net imports. Their most interesting findings are summarized in table 17, which considers the amount by which trade increases the (implicit) labor supply of different educational groups under three different technology assumptions. The "low" assumption means that the goods produced by LDCs use average current technology factor proportions. The "middle" assumption uses technologies that are ten to fifteen years old to estimate the factor proportions. And the "high" assumption assumes that the LDCs use technology from the 1970s. These proportions are based on the factor proportions in the relevant three-digit standard industrial classification from the appropriate period. There is no attempt to assess Robert Feenstra's argument that within-industry import-export behavior is more important than between-industry substitution in explaining the success of LDC penetration of U.S. product markets. If these estimates are to address the criticisms that have been leveled at the method, more data on LDC production processes and attention to within-industry import integration into the production process need to be included.

I think that the authors could make more progress. What is needed is some direct information on the age of the technology and on the processes used by the LDC producers. It is not clear that this evidence will support the high scenario. As Katz himself said at the Brookings 
Panel meeting, if they had the technical data on how goods were made in LDCs, the authors would not necessarily have concluded that LDC producers were using older technologies that embodied a lot of lower skilled labor in their goods.

Let me finally talk a little bit about the authors' overall estimates. Table 19 summarizes the factor proportional analysis. It does so under the middle assumptions, so that the importing industries are using technologies that are ten to fifteen years old and thus are embodying relatively more less skilled labor than do the best producers currently. As described above, according to their analysis, most of the effect is focused on the lowest skilled group; that is, there is a fall in the wage of high school dropouts relative to all others. The percentage contributions show that post-1979 immigration is responsible for a fairly large proportion of this decline; using the middle elasticity estimate, about 40 percent of the decline in the real wage of high school dropouts relative to all others.

But regardless of which assumptions are used, the rest of the labor market is not very much affected. What the authors ought to conclude is that, yet again, they have presented a substantial amount of evidence to indicate that it is a very specific part of the domestic labor marketthe less skilled group - that bears the brunt of the redistributional effect, both from immigration and from trade. The authors have marshaled a lot more evidence on the immigration side than was available before, but I do not think they have produced as much incremental evidence on the trade side. I would encourage them to obtain more direct evidence on the trade effects and to use less of the inferential evidence.

General discussion: William Branson described the paper as taking a closed economy view of trade effects because of its emphasis on quantities rather than relative prices. A model better reflecting the "trade view" would start with other countries having different factor endowment ratios, and so different factor price ratios, than the United States. As barriers to trade are lowered, the relative factor returns become more equal. In the United States, this results in a rise in the returns to skilled labor relative to unskilled labor. He noted that everything works off these relative price changes in this model, and quantities need not change much for trade to have these effects. Katz replied that in generalequilibrium models such as Paul Krugman's, the factor content of trade 
gives the same results as do the price changes. Since it is easier to work with quantities than prices in such a framework, he regarded the methodology in the paper as the right way to proceed. However, he acknowledged that the model could miss some trade effects operating only through prices, such as cases where workers receive rents that are eroded just by the threat of trade, when trade barriers fall. Robert Hall observed that by focusing on real GDP rather than consumption, the paper does not adequately measure the benefits of trade. If the terms of trade shift in favor of a country, GDP may not rise, although properly deflated real incomes will.

Branson also noted that Europe and the United States have had very different labor market outcomes in terms of wages and unemployment over the past decade, which suggests two different ways of reacting to the same shock. Katz saw this as evidence that institutions matter in determining wage outcomes. He also noted that countries with faster growth in the relative supply of educated workers had smaller increases in inequality, which conflicts with the "trade view" that only world factor proportions matter. He knew of no theoretical model that could integrate globalization and domestic institutions. Freeman pointed out another broad outcome not predicted by trade models: as the percentage of goods from LDCs increases, predominantly in industries such as apparel that disproportionately employ women, women's wages should fall. Yet they have risen in the United States and elsewhere, indicating that other factors have dominated women's relative wages.

William Nordhaus questioned some of the paper's other assumptions. He was curious about the evidence underlying the assumption of complementarity between skilled workers and capital. He had serious reservations about the returns to scale of the production function, which effectively assumes that immigrants can spread out without any congestion effects. Adding land, or any fixed factor, would make a large change to the calculated benefits of immigration. For example, putting land and other fixed factors into a Cobb-Douglas production function with a conservative coefficient of 0.05 and adding 5 percent to the labor force results in an $\$ 18$ billion penalty for the labor increase, enough to reverse the sign of net benefits. And this does not even account for environmental effects, such as fixed national quotas on greenhouse gas emissions or sulfur dioxide, or congestion effects, which are likely to be important since the immigrants are going to some of the most con- 
gested parts of the country. He suggested that a measure of sustainable consumption by natives would better capture these effects. Robert Hall responded that there are positive externalities that could reverse these conclusions. Their existence is revealed by immigrants' own choices of where to live: they choose high-density areas because that is where the wages are highest, exactly because of these externalities. Even the notion that the United States is being overwhelmed by congestion is inaccurate, since studies have found, for example, that commuting times in Los Angeles have actually declined since 1950. Nordhaus clarified that he was not addressing the level of congestion today, but rather that the cost of adding to it through immigration was not being measured.

Several panelists discussed the use of educational attainment in the analysis of relative wages. Jonathan Gruber questioned whether years of schooling should have the same effect if they were received in the United States or abroad. James Duesenberry remarked that comparing years of schooling across time periods is hazardous, noting that in 1960, 49.5 percent of workers were high school dropouts, while in 1995 only 9 percent were. In addition, the personal characteristics of dropouts has changed dramatically over this period, as entirely different social forces have influenced whether people finished high school. Robert Shiller suggested that education is basically signaling, and the signal from any level of educational attainment changes over time. People in the category of dropout have changed over time; currently there are so few, and they tend to have specific ability differences, such as executive dysfunctions (where they are unreliable), attention deficit disorders, reading disabilities, or mental illnesses. He suggested using characteristics such as these, rather than educational attainment.

Katz noted that the paper is not assuming that high school dropouts were the same now as in 1960, but rather that the gap between the people in adjoining educational attainment cells is comparable. The evidence from the distribution of income, comparing the wages of the top twentieth percentile with the bottom eightieth, for example, indicates that the gap has been relatively steady. Regarding the type of data that Shiller suggested, Katz believed that panels classifying such disorders would not indicate whether the people were immigrants and so are not applicable to the paper's purpose. Freeman added that while Shiller raised the possibility that the rise in inequality reflected a drop 
in the abilities of people in the bottom groups, results from following cohorts of the same people revealed that wage trends are found within cohorts. Looking at high school dropouts from twenty-five years ago, wages were stable at first but have fallen sharply in the last twenty years.

Nordhaus suggested giving more attention to ethnicity, in addition to skills and education. According to assimilationists, immigrants face a wage penalty, but after a few generations their descendants regress toward the national average. Historically, Mexican immigrants have been the exception, suffering a wage penalty that has worsened over generations. Now native-born Hispanics might experience a similar effect with recent immigration depressing their earnings.

Nordhaus also observed that the paper's finding that immigration rather than trade accounted for the relative wage declines of the poorest workers is not reflected in the political discussion, which stresses trade protection over immigration reform. He recognized that attacks on immigration have always sounded a little Philistine and surely not politically correct. Yet in light of the effects of immigration on the bottom fifth of the income distribution, it was hard to avoid the conclusion that present immigration policies are badly flawed. 


\section{References}

Altonji, Joseph G., and David E. Card. 1991. "The Effects of Immigration on the Labor Market Outcomes of Less-Skilled Natives." In Immigration, Trade, and the Labor Market, edited by John M. Abowd and Richard B. Freeman. University of Chicago Press.

Autor, David H., Lawrence F. Katz, and Alan B. Krueger. 1997. " Computing Inequality: Have Computers Changed the Labor Market?" Working Paper 5956. Cambridge, Mass.: National Bureau of Economic Research (March).

Baldwin, Robert E., and Glen G. Cain. 1997. "Shifts in U.S. Relative Wages: The Role of Trade, Technology, and Factor Endowments."' Working Paper 5934. Cambridge, Mass.: National Bureau of Economic Research (February).

Bartel, Ann P. 1989. "Where Do the New U.S. Immigrants Live?"' Journal of Labor Economics 7(4): 371-91.

Berman, Eli, John Bound, and Zvi Griliches. 1994. "Changes in the Demand for Skilled Labor within U.S. Manufacturing: Evidence from the Annual Survey of Manufactures." Quarterly Journal of Economics 109(2): 367-97.

Bernard, Andrew B., and J. Bradford Jensen. 1995. "Exporters, Jobs, and Wages in U.S. Manufacturing: 1976-1987.' BPEA, Microeconomics, 1995, 67-119.

Bhagwati, Jagdish, and Vivek H. Dehejia. 1994. "Freer Trade and Wages of the Unskilled-Is Marx Striking Again?"' In Trade and Wages: Leveling Wages Down?, edited by Jagdish Bhagwati and Marvin H. Kosters. Washington: American Enterprise Institute.

Blanchard, Olivier Jean, and Lawrence F. Katz. 1992. "Regional Evolutions." BPEA, 1:1992, 1-75.

Blau, Francine D., and Lawrence M. Kahn. 1996. "International Differences in Male Wage Inequality: Institutions versus Market Forces." Journal of Political Economy 104(4): 791-836.

Borjas, George J. 1990. Friends or Strangers: The Impact of Immigrants on the U.S. Economy. Basic Books.

. 1994. "The Economics of Immigration." Journal of Economic Literature 32(4): 1667-717.

1995. "The Economic Benefits from Immigration." Journal of Economic Perspectives 9(2): 3-22.

Borjas, George J., Richard B. Freeman, and Lawrence F. Katz. 1992. "On the Labor Market Effects of Immigration and Trade." In Immigration and the Work Force: Economic Consequences for the United States and Source Areas, edited by George J. Borjas and Richard B. Freeman. University of Chicago Press. 
1996. "Searching for the Effect of Immigration on the Labor Market.", American Economic Review, Papers and Proceedings 86(2): 246-51.

Borjas, George J., and Valerie A. Ramey. 1995. "Foreign Competition, Market Power, and Wage Inequality.' Quarterly Journal of Economics 110(4): 1075-110.

Bound, John, and George Johnson. 1992. "Changes in the Structure of Wages in the 1980's: An Evaluation of Alternative Explanations.' American Economic Review 82(3): 371-92.

$\rightarrow$ Butcher, Kristin F., and David E. Card. 1991. "Immigration and Wages: Evidence from the 1980's.' American Economic Review, Papers and Proceedings 81(2): 292-96.

Butcher, Kristin F., and John DiNardo. 1997. "The Immigrant and NativeBorn Wage Distributions: Evidence from United States Censuses.' Unpublished paper. Boston University and University of California, Irvine (June).

Card, David E. 1990. "The Impact of the Mariel Boatlift on the Miami Labor Market.' Industrial and Labor Relations Review 43(2): 245-57.

. 1997. "Immigrant Inflows, Native Outflows, and the Local Labor Market Impacts of Higher Immigration,’' Working Paper 5927. Cambridge, Mass.: National Bureau of Economic Research (February).

Davis, Donald R. 1996. “'Does European Unemployment Prop Up American Wages?' Working Paper 5620. Cambridge, Mass.: National Bureau of Economic Research (June).

Deardorff, Alan V, and Dalia S. Hakura. 1994. "Trade and Wages-What are the Questions?' In Trade and Wages: Leveling Wages Down?, edited by Jagdish Bhagwati and Marvin H. Kosters. Washington: American Enterprise Institute.

Deardorff, Alan V., and Robert W. Staiger. 1988. “An Interpretation of the Factor Content of Trade.' Journal of International Economics 24(1-2): 93107.

Doms, Mark, Timothy Dunne, and Kenneth R. Troske. 1997. “Workers, Wages, and Technology." Quarterly Journal of Economics 112(1): 253-90.

Edin, Per-Anders, and Bertil Holmlund. 1995. "The Swedish Wage Structure: The Rise and Fall of Solidarity Wage Policy?' In Differences and Changes in Wage Structures, edited by Richard B. Freeman and Lawrence F. Katz. University of Chicago Press.

Filer, Randall K. 1992. "The Effect of Immigrant Arrivals on Migratory Patterns of Native Workers.' In Immigration and the Work Force: Economic Consequences for the United States and Source Areas, edited by George J. Borjas and Richard B. Freeman. University of Chicago Press.

Fortin, Nicole, and Thomas Lemieux. 1996. “Rank Regression, Wage Distributions, and the Gender Gap.', CRDE Working Paper 1096. University of Montreal (April). 
Frankel, Jeffrey A., and David Romer. 1996. "Trade and Growth: An Empirical Investigation." Working Paper 5476. Cambridge, Mass.: National Bureau of Economic Research (March).

Freeman, Richard B. 1975. "Overinvestment in College Training?" Journal of Human Resources 10(3): 287-311.

Freeman, Richard B., and Lawrence F. Katz. 1994. "Rising Wage Inequality: The United States vs. Other Advanced Countries." In Working Under Different Rules, edited by Richard B. Freeman. Russell Sage Foundation.

Freeman, Richard B., and Karen Needels. 1993. "Skill Differentials in Canada in an Era of Rising Labor Market Inequality." In Small Differences That Matter: Labor Markets and Income Maintenance in Canada and the United States, edited by David E. Card and Richard B. Freeman. University of Chicago Press.

Frey, William H. 1994. "The New White Flight." American Demographics 16(4): 40-48.

. 1995a. "Immigration and Internal Migration 'Flight' from U.S. Metropolitan Areas: Toward a New Demographic Balkanisation.' Urban Studies 32(4-5): 733-57.

. 1995b. "Immigration Impacts on Internal Migration of the Poor: 1990 Census Evidence for U.S. States." International Journal of Population Geography 1: 51-67.

Frey, William H., and Kao-Lee Liaw. 1996. "The Impact of Recent Immigration on Population Redistribution within the United States." Research Report 96-376. University of Michigan, Population Studies Center (December).

Friedberg, Rachel M. 1996. "The Impact of Mass Migration on the Israeli Labor Market." Unpublished paper. Brown University (November).

Grossman, Jean Baldwin. 1982. "The Substitutability of Natives and Immigrants in Production." Review of Economics and Statistics 64(4): 596-603.

Hamermesh, Daniel S. 1993. Labor Demand. Princeton University Press.

. 1997. "Immigration and the Quality of Jobs." Unpublished paper. University of Texas (February).

Hanson, Gordon H., and Antonio Spilimbergo. 1997. "Illegal Immigration, Border Enforcement, and Relative Wages: Evidence from Apprehensions at the U.S.-Mexico Border." Unpublished paper. University of Texas (March).

Jaeger, David A. 1995. "Skill Differences and the Effect of Immigrants on the Wages of Natives." Unpublished paper. U.S. Bureau of Labor Statistics (November).

1997. "Reconciling the Old and New Census Bureau Education Questions: Recommendations for Researchers." Journal of Business and Economic Statistics 15(3): 300-09.

Jensen, J. Bradford, and Kenneth R. Troske. 1997. “Increasing Wage Disper- 
sion in U.S. Manufacturing: Plant-Level Evidence on the Role of Trade and Technology.' Paper prepared for the Council on Foreign Relations Study Group on Global Trade and Wages (March).

Johnson, George E. 1997a. "Changes in Earnings Inequality: The Role of Demand Shifts." Journal of Economic Perspectives 11(2): 41-54.

1997b. "Estimation of the Impact of Immigration on the Distribution of Income Among Minorities and Others." Unpublished paper. University of Michigan (February).

Katz, Lawrence F., and Kevin M. Murphy. 1992. "Changes in Relative Wages, 1963-1987: Supply and Demand Factors." Quarterly Journal of Economics 107(1): 35-78.

Kim, Dae-Il, and Robert H. Topel. 1995. "Labor Markets and Economic Growth: Lessons from Korea's Industrialization, 1970-1990." In Differences and Changes in Wage Structures, edited by Richard B. Freeman and Lawrence F. Katz. University of Chicago Press.

Krueger, Alan B. 1997. "Labor Market Shifts and the Price Puzzle Revisited." Working Paper 5924. Cambridge, Mass.: National Bureau of Economic Research (February).

Krugman, Paul R. 1995a. "Growing World Trade: Causes and Consequences." BPEA, 1:1995, 327-77.

1995b. "Technology, Trade, and Factor Prices." Working Paper 5355. Cambridge, Mass.: National Bureau of Economic Research (November).

LaLonde, Robert J., and Robert H. Topel. 1991. "Labor Market Adjustments to Increased Immigration." In Immigration, Trade, and the Labor Market, edited by John M. Abowd and Richard B. Freeman. University of Chicago Press.

Lawrence, Robert Z. 1996. Single World, Divided Nations? International Trade and OECD Labor Markets. Paris: Brookings and Organisation for Economic Co-operation and Development.

Lawrence, Robert Z., and Matthew J. Slaughter. 1993. "International Trade and American Wages in the 1980s: Giant Sucking Sound or Small Hiccup?", BPEA, Microeconomics 2:1993, 161-226.

Leamer, Edward E. 1996a. "In Search of Stolper-Samuelson Effects on U.S. Wages." Working Paper 5427. Cambridge, Mass.: National Bureau of Economic Research (January).

. 1996b. "What's the Use of Factor Contents?" Working Paper 5448. Cambridge, Mass.: National Bureau of Economic Research (February).

Mishel, Lawrence, Jared Bernstein, and John Schmitt. 1997. The State of Working America, 1996-97. Armonk, N.Y.: M. E. Sharpe.

Mundell, Robert A. 1957. "International Trade and Factor Mobility." American Economic Review 47(3): 321-35. 
Murphy, Kevin M., and Finis Welch. 1992. “The Structure of Wages.” Quarterly Journal of Economics 107(1): 285-326.

Rodrik, Dani. 1997. Has Globalization Gone Too Far? Washington: Institute for International Economics.

Sachs, Jeffrey D., and Howard J. Shatz. 1994. "Trade and Jobs in U.S. Manufacturing."' BPEA, 1:1994, 1-84.

Sachs, Jeffrey D., and Andrew Warner. 1995. "Economic Reform and the Process of Global Integration." BPEA, 1:1995, 1-118.

Schmitt, John. 1995. "The Changing Structure of Male Earnings in Britain, 1974-1988." In Differences and Changes in Wage Structures, edited by Richard B. Freeman and Lawrence F. Katz. University of Chicago Press.

Schoeni, Robert F. 1996. "The Effect of Immigrants on the Employment and Wages of Native Workers: Evidence from the 1970s and 1980s.' Unpublished paper. RAND (February).

Trefler, Daniel. 1993. "International Factor Price Differences: Leontief Was Right!'” Journal of Political Economy 101(6): 961-87.

Troske, Kenneth R. 1995. "The Worker Establishment Characteristics Database." Research Paper 95-10. U.S. Bureau of the Census, Center for Economic Studies (June).

U.S. Bureau of the Census. 1989. "The Relationship between the 1970 and 1980 Industry and Occupation Classification Systems" Technical Paper 59. Department of Commerce (February).

White, Michael J., and Lori M. Hunter. 1993. "The Migratory Response of Native-Born Workers to the Presence of Immigrants in the Labor Market." Working Paper 93-08. Brown University, Population Studies and Training Center (July).

Wood, Adrian. 1994. North-South Trade, Employment, and Inequality: Changing Fortunes in a Skill-Driven World. Oxford: Clarendon Press.

- 1995. "How Trade Hurt Unskilled Workers." Journal of Economic Perspectives 9(3): 57-80. 